\title{
28. LOWER CRETACEOUS MAGNETOSTRATIGRAPHY AND PALEOLATITUDES OFF NORTHWEST AUSTRALIA, ODP SITE 765 AND DSDP SITE 261, ARGO ABYSSAL PLAIN, AND ODP SITE 766, GASCOYNE ABYSSAL PLAIN ${ }^{1}$
}

\author{
James G. Ogg, ${ }^{2}$ Kazuto Kodama, ${ }^{3}$ and Brian P. Wallick ${ }^{2}$
}

\begin{abstract}
Lower Cretaceous sediments were sampled for magnetostratigraphy at three sites. ODP Site 765 and DSDP Site 261, in the Argo Abyssal Plain, consist primarily of brownish-red to gray claystone having hematite and magnetite carriers of characteristic magnetization. ODP Site 766, in the Gascoyne Abyssal Plain, consists mainly of dark greenish-gray volcaniclastic turbidites with magnetite as the carrier of characteristic magnetization. Progressive thermal demagnetization (Sites 765 and 261) or alternating field demagnetization (Site 766) yielded well-defined polarity zones and a set of reliable paleolatitudes.

Magnetic polarity chrons were assigned to polarity zones using biostratigraphic correlations. Late Aptian chron $\mathrm{M}^{\prime \prime}-1 " \mathrm{r}$, a brief reversed-polarity chron younger than M0r, is a narrow, $40-\mathrm{cm}$ feature delimited in Hole $765 \mathrm{C}$. Early Aptian reversed-polarity chron M0r is also present in Hole 765C. Polarity chrons M1r through M3r were observed in the Barremian of all three sites. Valanginian and Hauterivian polarity chrons can be tentatively assigned to polarity zones only in Hole 766A.

The paleolatitude of this region remained at $35^{\circ}$ to $37^{\circ} \mathrm{S}$ from the Berriasian through the Aptian. During this interval, there was approximately $16^{\circ}$ of clockwise rotation, with the oriented sample suites of Site 765 displaying a Berriasian declination of $307^{\circ}$ to an Aptian declination of $323^{\circ}$. These results are consistent with the interpolated Early Cretaceous apparent polar wander for Australia, but indicate that this region was approximately $5^{\circ}$ farther north than predicted.
\end{abstract}

\section{INTRODUCTION}

One of the main goals of Leg 123 drilling off Northwest Australia was the improvement of the Mesozoic, particularly the Late Jurassic to Early Cretaceous, magneto-biostratigraphic time scale for southern latitudes. Thick sections of Lower Cretaceous strata were recovered at Site 765 in the Argo Abyssal Plain $\left(16.0^{\circ} \mathrm{S}, 117.6^{\circ} \mathrm{E}\right)$ and at Site 766 at the foot of the Exmouth Plateau facing the Gascoyne Abyssal Plain $\left(19.9^{\circ} \mathrm{S}, 110.5^{\circ} \mathrm{E}\right)$ (Fig. 1). Site 261 of DSDP Leg 27 had discontinuous coring of Upper Jurassic-Lower Cretaceous strata in the Argo Abyssal Plain $\left(12.9^{\circ} \mathrm{S}, 117.9^{\circ} \mathrm{E}\right)$ near ODP Site 765 . Drilling at all sites penetrated basaltic basement.

The objectives of this paleomagnetic project were (1) to obtain magnetostratigraphic correlations among the three sites, (2) to correlate the magnetic polarity pattern to the magnetic polarity time scale as compiled from pelagic sediments of the low-latitude Atlantic-Tethyan faunal realm, and (3) to obtain Early Cretaceous paleolatitudes for this portion of the Australian Plate.

For ODP Sites 765 and 766 , preliminary magnetic polarity interpretations based upon shipboard measurements and partial shore-based analyses were presented in the Initial Reports volume for Leg 123 (Shipboard Scientific Party, 1990a, 1990b). Upon more thorough analyses using progressive thermal demagnetization or high levels of alternating field demagnetization, some of these shipboard interpretations were discovered to be incorrect. Jarrard (1974) analyzed a few paleomagnetic samples of Lower Cretaceous sediments of DSDP Site 261; the reported normal polarity for all strata is an artifact of inadequate demagnetization, as will be discussed later.

\footnotetext{
${ }^{1}$ Gradstein, F. M., Ludden, J. N., et al., 1992. Proc. ODP, Sci. Results, 123 College Station, TX (Ocean Drilling Program).

Department of Earth and Atmospheric Science, Purdue University, West Lafayette, IN 47907, U.S.A.

${ }^{3}$ Department of Geology, Faculty of Science, Kochi University, Kochi 780 ,
}

The main results of this study are (1) through the Early Cretaceous, this portion of the Australian Plate had a paleolatitude of $35^{\circ}$ to $37^{\circ} \mathrm{S}$, but experienced a $15^{\circ}$ to $20^{\circ}$ clockwise rotation; (2) a brief reversed-polarity chron, $\mathrm{M}^{\prime \prime}-1$," occurs in the mid-Aptian; (3) M-sequence polarity chrons have been assigned to strata in Sites 765,261 , and 766 , enabling one to improve precision for ages and sedimentation rates; and (4) partial magnetostratigraphic correlations can be made between Site 765 and Site 261 for the Lower Cretaceous claystones, thereby indicating that the reported "Aptian" of Site 261 (Veevers, Heirtzler, et al., 1974) is Barremian in age.

\section{EARLY CRETACEOUS MAGNETIC POLARITY TIME SCALE}

The standard magnetic polarity scale and associated nomenclature for polarity chrons of the Late Jurassic and Early Cretaceous are derived from the Hawaiian marine magnetic anomaly pattern that resulted from the ancient spreading center between the Pacific and Farallon plates (reviewed in Larson and Hilde, 1975). This "M-sequence" pattern has been correlated to other magnetic anomaly lineations in the Pacific, Atlantic, and Indian ocean basins (e.g., Vogt and Einwich, 1979; Schouten and Klitgord, 1977, 1982; Sundvik, 1985; Klitgord and Schouten, 1987; Fullerton et al., 1989), although some uncertainities are present when correlating the M11 through M4 portion (late Valanginian through early Barremian). Implicit in the M-sequence standard scale is the assumption that the Hawaiian lineations were formed by a constant spreading rate for a $40-$ m.y. interval without ridge jumps or other complications.

Magnetostratigraphic studies of pelagic sediment sections in southern Europe and in the Atlantic Ocean have enabled paleomagnetists to correlate the majority of the $\mathrm{M}$-sequence patterns to biostratigraphic zonations of the Tethyan faunal realm. Magnetic polarity chrons have been correlated to (1) ammonite zones of the late Oxfordian through early Valanginian (Ogg et al., 1984, 1988; Galbrun, 1984, 1985), (2) calpionellid zones of the late Tithonian 


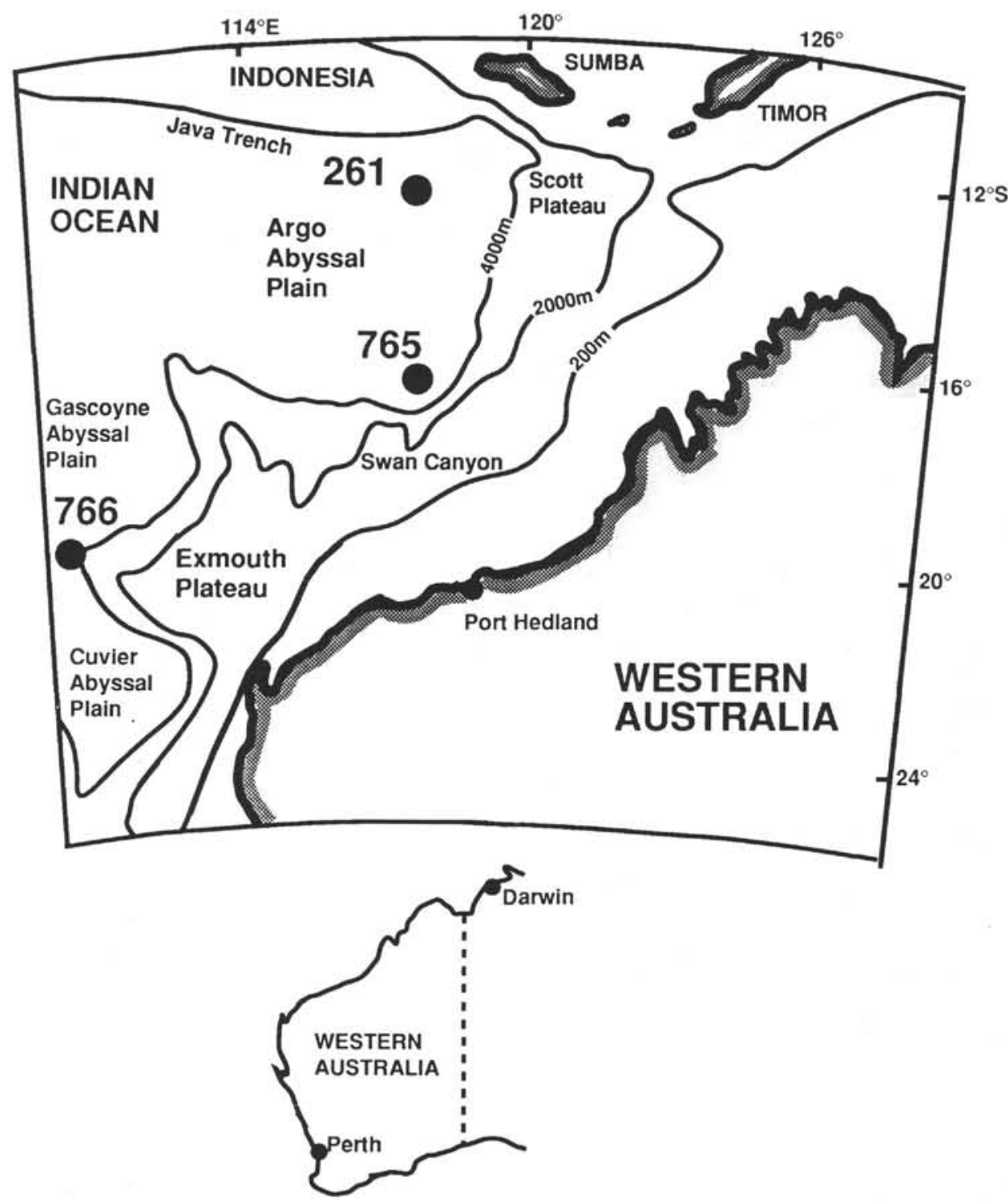

Figure 1. Generalized bathymetry of the northwestern Australian margin and locations of Sites 765 and 766 and DSDP Site 261.

through early Valanginian (Ogg, 1983; Lowrie and Channell, 1984; Galbrun, 1984; Marton, 1986; Channell and Grandesso, 1987; Ogg et al., in press), (3) nannofossil appearance and extinction datum horizons of the Tithonian through Aptian (Ogg, 1983, 1988; Bralower, 1987; Channell et al., 1987; Bralower et al., 1989; Ogg et al., in press), (4) dinoflagellate appearance and extinction datum horizons of the Tithonian through Aptian (Ogg, 1983; Ogg et al., in press), and (5) foraminifer zones of the Hauterivian through Aptian (Channell et al., 1979; Lowrie and Alvarez, 1984). These magnetostratigraphic-biostratigraphic correlations were compiled in various review articles (e.g., Kent and Gradstein, 1985; Lowrie and Ogg, 1986; Ogg and Lowrie, 1986; Ogg, 1988; Ogg and Steiner, 1988; Ogg, in press; Ogg et al., in press).

The magnetic polarity time scale for the Late Jurassic and Early Cretaceous can be summarized briefly by the assignment of geological stage boundaries to polarity chrons. Nomenclature of polarity chrons follows that of Cox in Harland et al. (1982):
Aptian/Barremian = just prior to $\mathrm{M} 0 \mathrm{r}$ Barremian/Hauterivian $=$ M5r to $\mathrm{M} 7 \mathrm{r}$ [depending upon biostratigraphic recognition of boundary]

Hauterivian/Valanginian $=$ approximately $\mathrm{M} 10 \mathrm{Nr}$

Valanginian/Berriasian $=$ middle of $\mathrm{M} 15 \mathrm{n}$

Berriasian/Tithonian = base of M18r or middle of M19n [depending upon definition of Jurassic-Cretaceous boundary]

Tithonian/Kimmeridgian $=$ approximately M22An or upper M23n

Kimmeridgian/Oxfordian $=\mathrm{M} 24 \mathrm{Br}$ to $\mathrm{M} 25 \mathrm{r}$

Exact assignment of geologic age boundaries to polarity chrons is not possible because of the absence of standardized definitions for these boundaries and the unsuitability of many of the historical "type sections" of these stages for paleomagnetism. Indeed, the magnetic polarity time scale may eventually provide 
the means for global recognition, hence definition, of such geologic stage boundaries.

Biostratigraphic datum horizons vary in their position relative to polarity zones among stratigraphic sections and between ocean basins (Bralower, 1987; Ogg, 1987, 1988; Ogg and Steiner, 1988; Ogg et al., in press). There are many causes for these inconsistencies between biostratigraphic datum placement relative to magnetostratigraphy, including (1) diachronous appearance and disappearance of species between geographic or ecologic regions, (2) lag time in the setting of magnetization in the sediment (Channell et al., 1982), (3) differential preservation of taxa or discontinuous sedimentation (Bralower, 1987), (4) difficulty of finding the precise first or last occurrence of a taxon in a given section, and (5) inconsistencies in taxonomic recognition. Lower Cretaceous strata display significant variation in the sequence of nannofossil datum levels between the Pacific and Atlantic-Tethys basins (Bralower, 1987) and within the Atlantic-Tethys region.

The Mesozoic faunal-floral assemblages within the Indian Ocean basin differ significantly from the Atlantic-western Tethyan realm. Many of the key marker taxa used for constructing the magnetic polarity time scale for the Late Jurassic-Early Cretaceous are absent. In particular, calpionellids, typical Atlantic-type dinoflagellates, and several of the nannofossil markers (e.g., Nannoconus) have not been reported from the Lower Cretaceous strata of any of the DSDP-ODP sites in the Indian Ocean.

The absence of many key paleontological datums of the Early Cretaceous and the uncertainities in the relative age correspondence of some taxa that are present at these Indian Ocean sites are problems for the unambiguous assignment of magnetic polarity chrons to polarity zones observed within the sections, especially when the magnetic polarity sequence lacks a distinctive "fingerprint" pattern.

\section{ANALYTICAL METHODS AND DATA INTERPRETATION}

Directions of natural remanent magnetization (NRM) and remanent magnetization after alternating field $(\mathrm{AF})$ demagnetization treatments of 10 and $15 \mathrm{mT}$ were measured at $5-\mathrm{cm}$ intervals of the archive halves of Lower Cretaceous cores using the automated 2G long-core cryogenic magnetometer on board the JOIDES Resolution. Details of these analytical procedures and shipboard results are found in the explanatory notes and appropriate site chapters in the Initial Reports volume of Leg 123 (Ludden, Gradstein, et al., 1990). These shipboard measurements were adequate for making preliminary findings about the main features of the magnetic polarity zonation and for estimating approximate paleolatitude ranges, but the details of the polarity sequence and precise paleolatitudes were possible only after progressive demagnetization and vector analysis of individual discrete samples.

\section{Discrete Sampling}

An average of three oriented paleomagnetic minicores $(2.5 \mathrm{~cm}$ in diameter, $2.4-2.5 \mathrm{~cm}$ long) were drilled perpendicular to the axis of the working half of each $1.5-\mathrm{m}$ section of recovered Lower Cretaceous strata of Holes $765 \mathrm{C}$ and 766A. In a few intervals of clay, it was necessary to use small plastic boxes to collect oriented cubic samples. As a result of the friable nature of the claystone and sandstone sediments upon drying, all minicores and cubic samples were sealed in aluminum foil with transfer of orientation marks prior to analyses and demagnetization treatments.

Sampling of Lower Cretaceous-uppermost Jurassic cores of DSDP Site 261 was performed in a similar fashion and sample spacing at the West Coast Core Repository.

The deviation of Hole $765 \mathrm{C}$ from vertical by $10^{\circ}$ to $15^{\circ}$ within the Lower Cretaceous strata enabled us to give most of the paleomagnetic samples an azimuth orientation with respect to the direction of apparent dip of bedding (Fig. 2). These relative azimuth orientations were used as a "field orientation" in the data analysis, with a corresponding "structural correction" performed on the final mean direction for each sample suite to compensate for the drillhole deviation, as will be detailed later.

The total number of discrete samples collected from Lower Cretaceous strata at these sites was approximately 250 samples from Hole 765C, 300 samples from Hole 766A, and 60 samples from Site 261.

\section{Cryogenic Magnetometer Measurements and Demagnetization Treatments}

Analyses of most of our sample suite from Site 261 were performed $2 \mathrm{yr}$ before the Leg 123 cruise. Measurements after progressive $\mathrm{AF}$ and thermal demagnetization were performed at the California Institute of Technology using a two-axis ScT cryogenic magnetometer housed in a mu-metal shielded room. Based on this earlier study and the results of pilot analyses of several samples from each of the Leg 123 sites, it was apparent that the reddish claystones of Site 765 required progressive thermal demagnetization, whereas the volcaniclastic-bearing siltstones and sandstones of Site 766 responded best to progressive AF demagnetization. Therefore, paleomagnetic analyses of the two sites were divided between two laboratories according to the availability of efficient demagnetization apparatus for large quantities of samples and of magnetic shielding.

Paleomagnetic analyses and thermal demagnetization were performed on samples from Site 765 and a second set from Site 261 at the University of Wyoming using a two-axis ScT cryogenic magnetometer and eight orientations per sample. The University of Wyoming magnetometer and oven-cooling chambers for thermal demagnetization are housed in a steel-shielded room having an internal field less than $1000 \mathrm{nT}$.

Samples from Site 766 were measured at Kochi University using an automated three-axis $2 \mathrm{G}$ cryogenic magnetometer and five orientations per sample. Progressive AF demagnetization was accomplished using a rotating sample holder within the AF coils.

Typical progressive thermal demagnetization for regular samples consisted of NRM, $350^{\circ} \mathrm{C}$, and $50^{\circ}$ increments between $450^{\circ}$ and $650^{\circ} \mathrm{C}$, with an additional $665^{\circ} \mathrm{C}$, if required. Typical progressive AF demagnetization for regular samples consisted of NRM, $10,20,30,35,40$, and $45 \mathrm{mT}$, followed by additional thermal demagnetization at $300^{\circ}$ and $400^{\circ} \mathrm{C}$, if required. More detailed progressive demagnetizations, especially at lower temperature or AF steps, were performed for pilots and for those samples for which detailed analysis was made of the secondary vs. characteristic magnetic vectors for use in determining the amount of plate rotation.

\section{Polarity Interpretations, Characteristic Directions, and Ratings}

For each sample, a vector plot of the directions of magnetization and intensities during progressive demagnetization was examined to assign polarity and to identify removed vectors of magnetic components (e.g., Fig. 3). The Australian Plate has experienced approximately $45^{\circ}$ of clockwise rotation since the Early Cretaceous (e.g., Embleton, 1984; Idnurm, 1985); therefore, the direction of present-day "north" overprints removed upon low levels of demagnetization aided in deciphering the polarity of the samples. The sites are and were south of the equator, therefore upward (negative) inclinations indicate normal polarity.

The direction of characteristic magnetization and associated variances were computed for each sample by applying a three-dimensional least-squares line fit to those sets of vectors in the plots that displayed removal of a single component, preferably univectorial toward the origin, during the higher demagnetization steps 


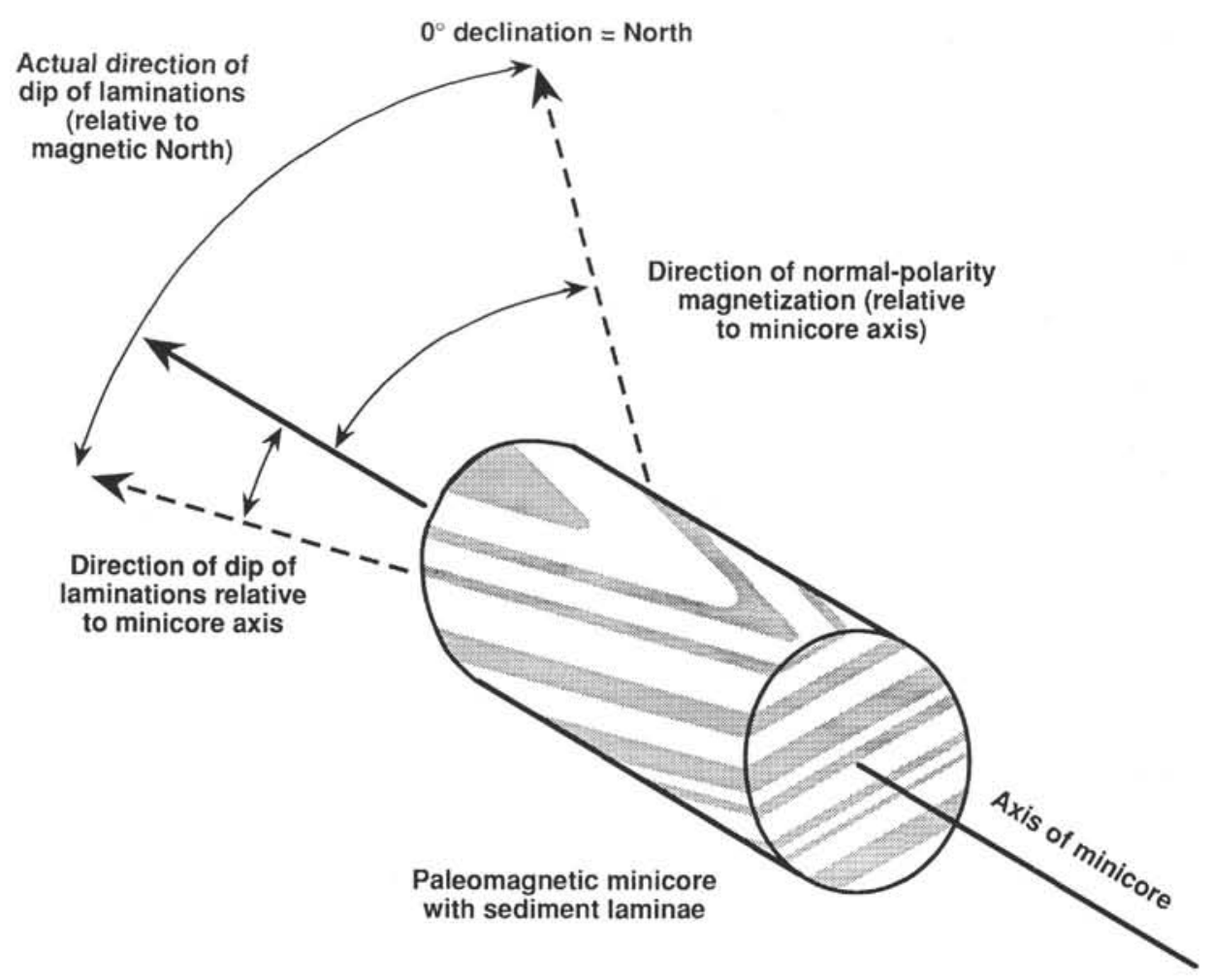

Figure 2. Orientation method for minicores using dipping laminae. The azimuth of apparent dip of the laminae relative to the axis of the minicore provides a means to orient each sample with respect to the next. This direction was used as a "field correction" on the sample orientation. The declination of normal polarity characteristic magnetization in this coordinate system (with respect to the direction of apparent dip) enables determination of the azimuth of dip of the laminae with respect to ancient north. Modified from Ogg (1987).

(method of Kirschvink, 1980). The intensity of characteristic magnetization was computed as the mean of the intensities of the vectors used in the least-squares fit.

Each characteristic direction was assigned a rating indicating its degree of precision (number of vectors used, their co-linearity, and univectorial trend toward origin) and the reliability of the assignment of polarity. These ratings are indicated in the magnetostratigraphic diagrams and are tabulated with the characteristic directions for the sample suites (Appendix on microfiche). The designations are as follows:

1. $\mathbf{N}$ or $\mathbf{R}$-polarity certain; characteristic direction incorporates at least three vectors having a high degree of linearity (standard deviation less than $5^{\circ}$ ) and a univectorial trend toward the origin, or at least four vectors displaying a linear trend that is not exactly toward the origin (thus indicating the presence of an overprint that resists high levels of demagnetization).

2. NP or RP - polarity certain; characteristic direction is obtained from two vectors having a univectorial trend toward the origin, from three or more vectors displaying a "noisy" linear trend (standard deviation greater than $5^{\circ}$ ), or from a stable "end point" (no significant change in magnetic direction or intensity for at least three demagnetization steps). These characteristic directions were assigned only half-weight in later computations of paleolatitude.

3. NPP or RPP - polarity is probably correct; characteristic direction is obtained from the "best step" reached during demagnetization or from two vectors displaying a general trend toward the origin. Samples having weak magnetizations (generally less than $\left.4 \times 10^{-5} \mathrm{~A} / \mathrm{m}\right)$, hence, a low signal/noise ratio, are also given this rating. These poor characteristic directions aid in indicating the polarity, but are omitted from later computations of paleolatitude.

4. N??, R?? or INT - polarity is questionable (sample did not respond well to demagnetization treatment or displayed erratic behavior) or is indeterminate or intermediate; characteristic direction is a "best step" and is omitted from paleolatitude computations. Such samples are not used in interpretation of polarity zones.

\section{Polarity Zones and Assignment of Polarity Chrons}

The polarity interpretations and characteristic directions and their ratings were plotted stratigraphically for each hole. Polarity zones, or clusters of samples having similar polarity, were diagrammed in a generalized polarity column.

"Orphan" samples, having polarity interpretations opposite those of adjacent blocks of samples, were represented by a short bar. These questionable events were usually ignored in the correlations of the magnetostratigraphy to the M-sequence, unless the close-spaced shipboard measurements also supported the existence of a short polarity zone.

Assignments of polarity chrons of the M-sequence magnetic polarity time scale to the polarity zones of the stratigraphic sections were based upon unique features of the polarity pattern, such as the extended interval of reversed polarity of polarity chron $\mathrm{M} 3 \mathrm{r}$, using biostratigraphic datum levels or zone assemblages as guides for correlation. Polarity chron assignments are further constrained by the magnetic anomaly age of basaltic basement (Fullerton et al., 1989). Distortions of the polarity pattern caused by variable sedimentation rates and by abundances of turbidites made a direct pattern match difficult. For Hole 766A, in which thick turbidite beds are present in a few intervals, an attempt was 
made to adjust the pattern for scattered pulses of voluminous sedimention. Discontinuous coring at Site 261 rendered it impossible to assign polarity zones directly; therefore, a composite polarity column was constructed for Sites 765 and 261 using lithologic features, such as bentonite beds, as a guide for correlation between sites.

\section{Paleolatitudes}

The true mean inclination, paleolatitude, and associated precision parameters were computed following the method of Kono (1980a, 1980b) for calculating statistics of inclination data from unoriented vertical drill cores. This method uses the mean and standard deviations of the sines of the inclinations to compensate for the circular Gaussian (Fisherian) distribution of paleomagnetic vectors. A simple mean of the inclinations gives unrealistic importance to the lower values. Kono's nonlinear simultaneous equations relating the true mean inclination, $I$, and the circular dispersion parameter, $K$, to the statistics of the sines of the inclination data were solved using Newton's method to converge on the solutions. Samples having characteristic directions rated NP or RP were given half-weight. To test the validity of Kono's procedure for middle latitutes, a previously analyzed set of Triassic data from Arctic islands (Ogg and Steiner, in press) was submitted to the same program; the resulting mean inclination is within $0.1^{\circ}$ of the inclination given by normal statistics on directional data (procedure modified from Fisher, 1953).

The radius of circle of $95 \%$ confidence of this true mean inclination is

$$
\alpha_{95}=\cos ^{-1}\left\{1-\left[20^{1 /(N-1)}-1\right][(N-1) /(K-1) N+1]\right\}
$$

where $N=$ effective number of samples (Kono, 1980a).

The radius of circle of standard deviation (63\% confidence interval) is

$$
\alpha_{63}=0.58 \alpha_{95} \quad \text { (McElhinny, 1973, p. 80). }
$$

Paleolatitude of the site is: Lat $=\tan ^{-1}[(\tan I) / 2]$, with confidence intervals derived by differentiation of the preceding equation, or

$$
d(\text { Lat })=0.5\left[1+3 \sin ^{2}(\text { Lat })\right] d I,
$$

where $d I=\alpha_{95}$ or $\alpha_{63}$, as desired.

\section{LOWER CRETACEOUS STRATIGRAPHY}

\section{Sites 765 and 261 (Argo Abyssal Plain)}

ODP Site 765 and DSDP Site 261 were drilled within the Argo Abyssal Plain, an oceanic basin that opened during the Late Jurassic as an unidentified block rifted toward the northeast, away from the northwest margin of Australia. The Late Jurassic sedimentary record, a main objective of Leg 123 drilling, remains enigmatic as a result of extreme condensation or nondeposition, biostratigraphic imprecision, and lack of recovery.

Site 261 was drilled near a magnetic anomaly tentatively identified as M24A (Fullerton et al., 1989; Sager et al., this volume) of Kimmeridgian age (Ogg et al., 1984). This magnetic anomaly interpretation is quite consistent with the Stephanolithion bigotii-Conusphaera mexicana minor(?) nannofossil assemblages of late Kimmeridgian-early Tithonian age found within the basal $20 \mathrm{~cm}$ of sediment (Core 27-261-33-1, 0-20 cm) of reddish-brown marl (Dumoulin and Bown, this volume). The Tithonian sequence at Site 261 is condensed, perhaps represented by only one core (Core 27-261-32) of brown calcareous claystone.
However, because of discontinuous coring, the actual stratigraphic thickness may range from 5 to $15 \mathrm{~m}$ or more. The Berriasian through Barremian strata consist of brown calcareous claystone overlain by gray claystone; the biostratigraphy provided only approximate ages throughout most of this $400-\mathrm{m}$ interval (Shipboard Scientific Party, 1974).

Site 765 was drilled on a magnetic anomaly that has been interpreted as M26 (Fullerton et al., 1989) of latest Oxfordian age (Ogg et al., 1984). The 10-cm unit of dusky red claystone (Sample $123-765 \mathrm{C}-62 \mathrm{R}-4,20-29 \mathrm{~cm}$ ) directly overlying the basaltic basement in Hole $765 \mathrm{C}$ is barren of fossils, as is the lowest $5 \mathrm{~m}$ of recovered dark brown silty claystone containing manganese micronodules (Shipboard Scientific Party, 1990a; Dumoulin and Bown, this volume). A late Berriasian to early Valanginian radiolarian assemblage was observed in Sample 123-765C-62R-1, $53-56 \mathrm{~cm}$; therefore, any Jurassic sediments, if present at Site 765 , must be extremely condensed.

Lower Cretaceous strata of Hole $765 \mathrm{C}$ are composed of Berriasian-lower Valanginian manganese-micronodule-rich brown silty claystone overlain by Valanginian to lower Aptian reddishbrown claystone (Leg 123 Shipboard Scientific Party, 1988). The reddish-brown claystone series has been subdivided into units and subunits by the presence of (1) bentonitic ash beds (Valanginian), (2) turbidite beds of nannofossil chalk (Hauterivian), (3) horizons rich in radiolarians (Barremian), and (4) enrichment in rhodochrosite concretions (lower Aptian). Greenish-gray mottling within these reddish claystones indicates that the depositional environment was oxidizing, with hematite precipitating near the sediment/water interface, while post-depositional reduction occurred later around burrow fillings or concentrations of organic matter. Therefore, one might expect that characteristic magnetizations carried by hematite are reliable recorders of the primary field direction.

These Lower Cretaceous sediments have several nannofossil, radiolarian, foraminiferal, and palynology datum levels or zonalcharacteristic assemblages that provide a general biostratigraphic framework (Shipboard Scientific Party, 1990a). Some of the geological ages assigned to these faunal-floral events conflict among different biostratigraphic methods, which is possibly an indication of the uncertainities in Indian Ocean Mesozoic biostratigraphy correlations to the western Tethys zonations.

The occurrence of bentonitic ash horizons, calcisphere-rich horizons, and lithologic color changes and a few common biostratigraphic markers provides a limited means of correlating the discontinuous-cored sediment column of Site 261 to the sediment facies of Site 765, although it is difficult to recognize the equivalents of some of the Site 765 lithologic subunits (Dumoulin and Bown, this volume, and pers. comm., 1989).

\section{Site 766 (Foot of Exmouth Plateau at Edge of Gascoyne Abyssal Plain)}

Site 766 was drilled into transitional crust at the edge of the Gascoyne Abyssal Plain. Its position $10 \mathrm{~km}$ landward of marine magnetic anomaly M10 (Fullerton et al., 1989) should predict a basal age of M10N-M11, or latest Valanginian-earliest Hauterivian (Bralower, 1987; Ogg, 1987, 1988). This age agrees with the radiolarian, dinoflagellate, and nannofossil assemblages for the oldest sediments overlying volcanics.

The uppermost Valanginian through Barremian sediments are dominated by dark greenish-gray turbidites of terrigenous clastics, with grains of glauconite, altered volcanoclastics, and bioclastics. The environment of deposition has been interpreted as a prograding submarine fan system of shallow marine sediment shed off the western rim of the Exmouth Plateau (Leg 123 Shipboard Scientific Party, 1988). The sharp facies change between Barremian glauconitic sandstone and Aptian siliceous chalk sug- 
A

Site 261

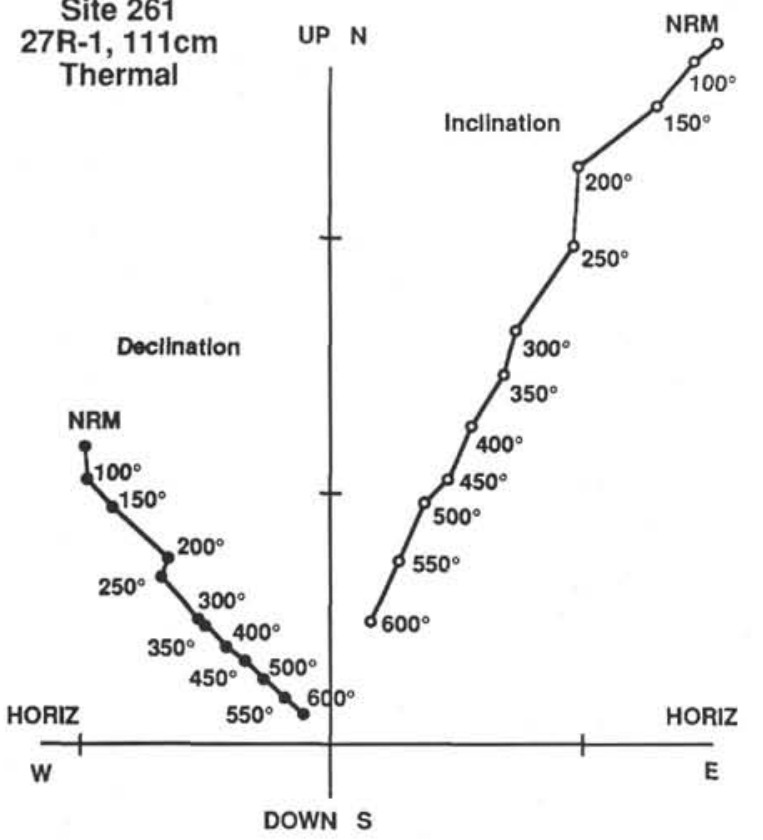

C

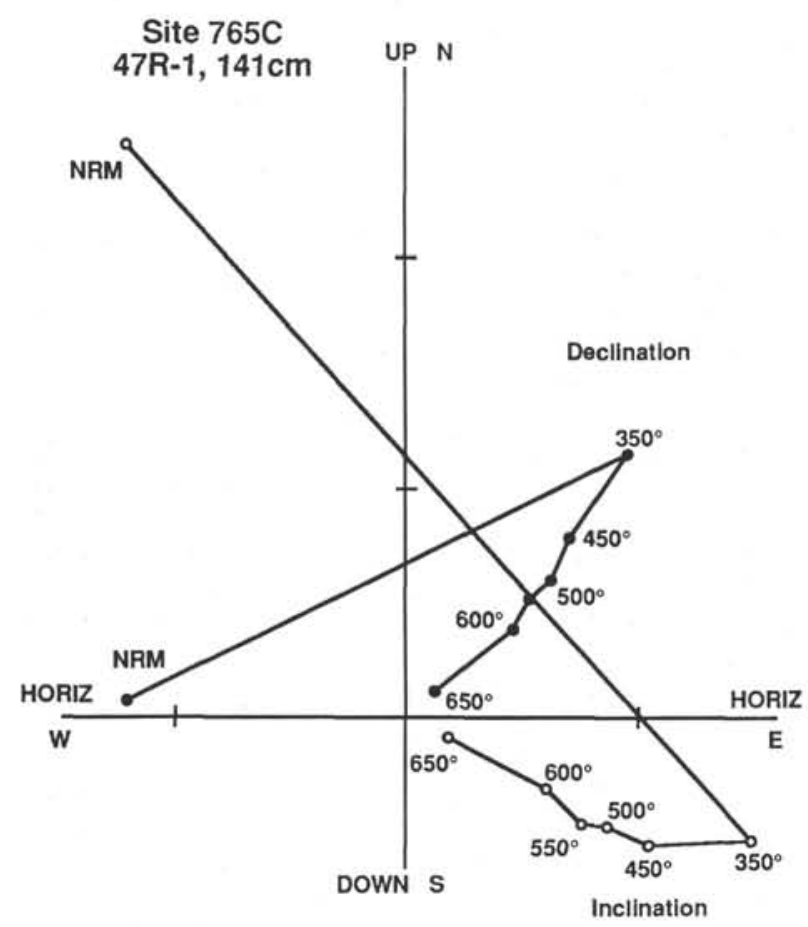

B

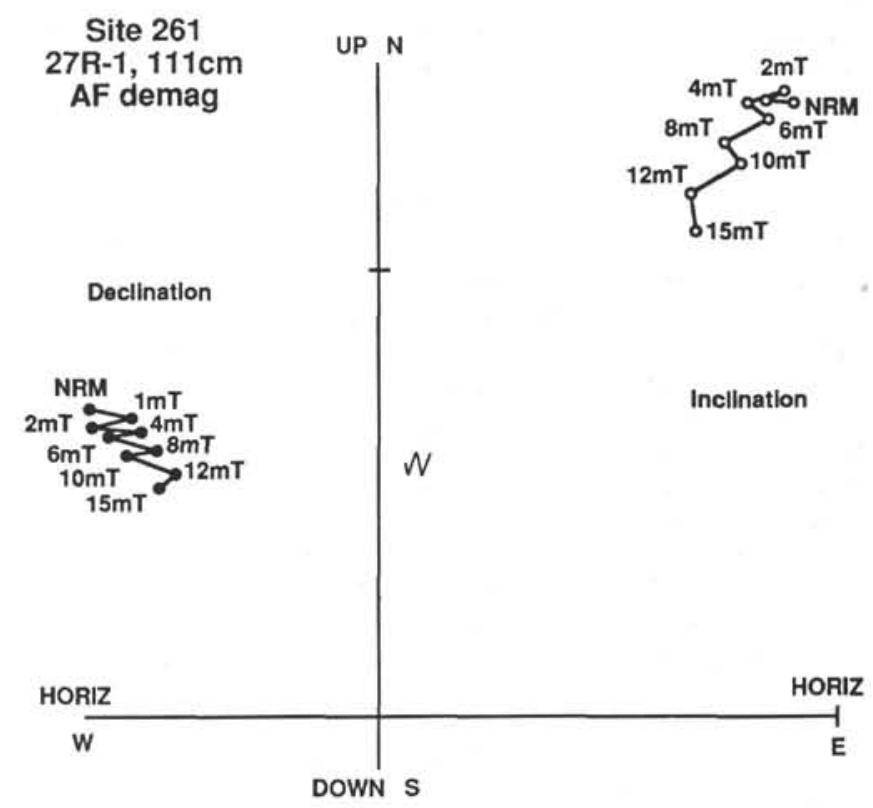

D

Site $765 \mathrm{C}$

$54 \mathrm{R}-3,112 \mathrm{~cm}$

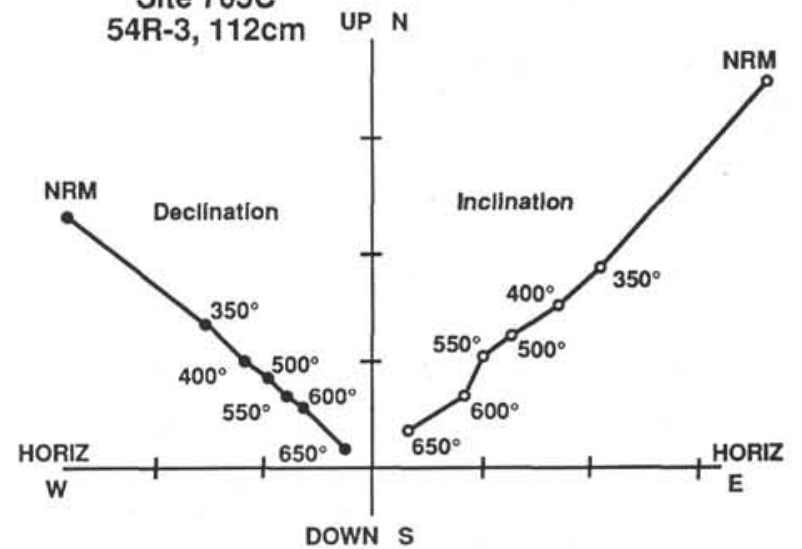

Figure 3. Vector plots of magnetic directions and intensities during demagnetization of typical samples from Sites 765 and 261 . On the vector plots, inclination (up, horizontal, down) is plotted with the total intensity of magnetization at the given demagnetization step. Declination (N, E, S, W) is plotted as the horizontal component of the magnetization vector. The initial (NRM) declination for samples from Site 261 is arbitrary because orientation control is lacking, and for many samples from Site 765 is relative to the direction of apparent dip. A., B. Comparison of thermal demagnetization (A) and AF field demagnetization (B) on halves of the same sample (27-261-27R-1,111 cm). Normal polarity (designated N) with characteristic direction $\left(-62.2^{\circ}\right.$ inclination) obtained by least-squares fit of the $400^{\circ}$ through $600^{\circ} \mathrm{C}$ steps $\left(1\right.$ scale division $\left.=5 \times 10^{-3} \mathrm{~A} / \mathrm{m}\right)$. C. Sample $123-765 \mathrm{C}-47 \mathrm{R}-1,141$ $\mathrm{cm}$, of reversed polarity (designated RP). Characteristic direction ( $26.5^{\circ}$ inclination, $49.1^{\circ}$ declination) obtained by least-squares fit of the $550^{\circ}$ through $650^{\circ} \mathrm{C}$ steps $\left(1\right.$ scale division $\left.=1 \times 10^{-4} \mathrm{~A} / \mathrm{m}\right)$. D. Sample $123-765 \mathrm{C}-54 \mathrm{R}-3,112 \mathrm{~cm}$, of normal polarity (designated NP). Characteristic direction $\left(-33.2^{\circ}\right.$ inclination, $312.7^{\circ}$ declination) obtained by least-squares fit of the $550^{\circ}$ through $650^{\circ} \mathrm{C}$ steps $\left(1\right.$ scale division $\left.=1 \times 10^{-3} \mathrm{~A} / \mathrm{m}\right) . \mathbf{E}$. Sample 123-765C-57R-1, $33 \mathrm{~cm}$, of reversed polarity, but poor stability (designated RPP). Characteristic direction $\left(45.0^{\circ}\right.$ inclination, $310.3^{\circ}$ declination) obtained by averaging the $550^{\circ}$ and $600^{\circ} \mathrm{C}$ steps $\left(1\right.$ scale division $\left.=5 \times 10^{-4} \mathrm{~A} / \mathrm{m}\right)$. 
E

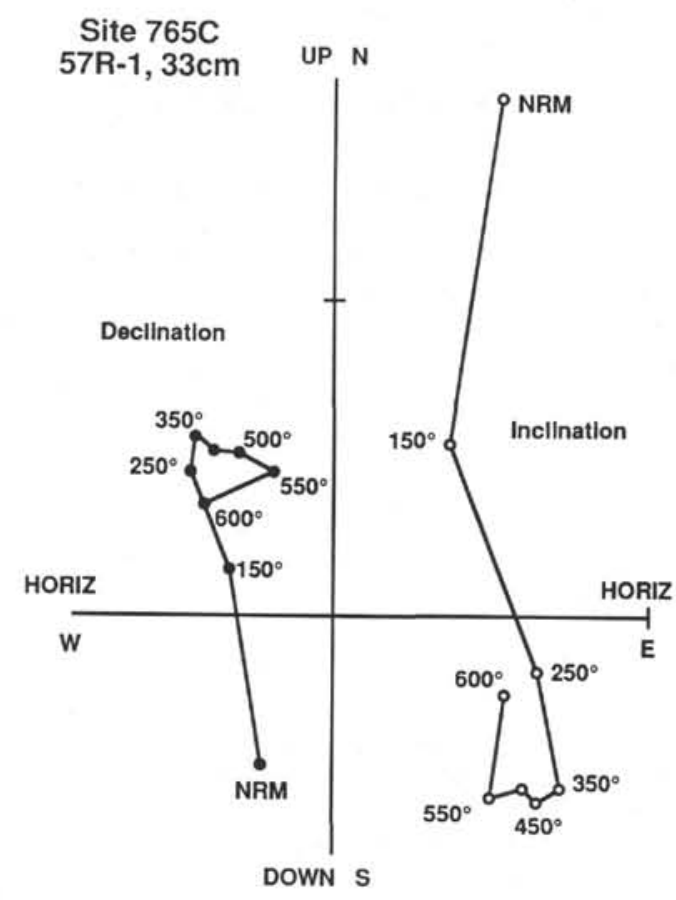

Figure 3 (continued).

gests a transgressive sequence boundary and the absence of upper Barremian and/or lower Aptian strata.

Only a few biostratigraphically significant datum levels of radiolarian, nannofossil, dinoflagellate, or foraminifer groups lie within the $225 \mathrm{~m}$ of uppermost Valanginian-Hauterivian-early Barremian (Shipboard Scientific Party, 1990b). The most significant datum for magnetostratigraphic correlations is the highest occurrence of Cruciellipsis cuviellieri within Core 123-766A33R; this datum occurs near the Hauterivian/Barremian boundary (or polarity chron M7r) in the Atlantic Basin (Ogg, 1987) or near polarity chron M8r in the western Tethys (Bralower, 1987). As noted above for Site 765 , the assigned geologic ages differ between faunal-floral zonations.

\section{MAGNETIC PROPERTIES}

Two main facies comprise the recovered Lower Cretaceous sequences of the three sites: reddish-brown to brown claystone to radiolarian-rich claystone of the Argo Abyssal Plain (Sites 765 and 261), and dark greenish-gray clastic-rich claystone to sandstone turbidites of Site 766. The magnetic behaviors of these two main facies and their subfacies are distinctively different, as are the demagnetization treatments required to obtain characteristic magnetic directions.

\section{Reddish-Brown Claystone (Sites 261 and 765)}

The magnetic properties of the lithologies from Sites 261 and 765 are similar. Reddish-brown claystones of both sites have a high intensity of natural remanent magnetization (NRM), generally ranging between 10 and $100 \mathrm{~mA} / \mathrm{m}$. Average susceptibility, as measured at Site 765 , is also relatively high, with typical $K \mathrm{~s}$ of $50 \times 10^{-6} \mathrm{cgs}$ and peaks exceeding $100 \times 10^{-6} \mathrm{cgs}$. The Barremian-Aptian samples generally appear toward the higher end of these ranges of NRM intensity and susceptibility; whereas, the Berriasian-Hauterivian samples are toward the lower end. Nearly all NRM directions had negative inclinations, suggesting the dominance of a secondary overprint of present-day magnetic field.

Thermal demagnetization generally is required to obtain primary magnetizations from reddish-colored pelagic sediments (e.g., Steiner, 1977; Lowrie and Heller, 1982; Ogg, 1983). Therefore, the earlier paleomagnetic study of this facies at Site 261, prior to common usage of thermal techniques, was unsuccessful in obtaining mixed polarity by application of AF demagnetization of $5 \mathrm{mT}$ (Jarrard, 1974). We also found that progressive AF demagnetization had only minor effects on the directions and intensities of magnetization of reddish samples of either site. Only intervals having greenish-gray coloration, hence having a magnetization not dominated by a hematite carrier, displayed significant demagnetization and indication of mixed polarity upon AF demagnetization to $15 \mathrm{mT}$. In contrast, progressive thermal demagnetization of these reddish claystones generally permitted separation of the various components and polarities of magnetization (Fig. 3).

The thermal demagnetization behavior of most samples revealed the presence of three components of magnetization. The first, a secondary component of normal polarity, was significantly removed upon heating to $300^{\circ} \mathrm{C}$, suggesting that it is carried by an iron hydroxide/oxide. The removal of this first component is best displayed in samples having reversed-polarity characteristic directions (Figs. 3C and 3E). A second component, noted in the majority of Site 765 samples, was removed after progressive heating to between $500^{\circ}$ and $600^{\circ} \mathrm{C}$ and is presumed to be carried by magnetite. The magnetization vector removed between $300^{\circ}$ and $550^{\circ} \mathrm{C}$ is considered to be the characteristic direction of magnetization for these sample suites. The directions of magnetization at $600^{\circ}$ and above, which are presumed to be carried by hematite, are not significantly different from those of the magnetite-carried component removed during intermediate thermal demagnetization. This behavior indicates that both magnetite and hematite are carriers of the primary magnetization and that the hematite carrier was probably formed during surface oxidation of the sediment.

Only minor exceptions were noted from this general demagnetization behavior, with the most notable being exhibited by Barremian turbidites at Site 765 (lithologic Subunit VC). Figure $3 \mathrm{E}$ illustrates the typical erratic behavior upon thermal demagnetization of samples in this interval.

\section{Dark Greenish-Gray Claystone to Sandstone (Site 766)}

Intensities of NRM vary by two orders of magnitude according to lithology and are mirrored by major changes in susceptibility (Shipboard Scientific Party, 1990b). Relatively low NRM intensities, $10^{-4}$ to $10^{-3} \mathrm{~A} / \mathrm{m}$, are characteristic of the Barremian dark greenish-gray to black claystone of lithologic Subunit IIIA (susceptibility Unit S-4) and of the lower Hauterivian pyrite-rich black siltstone in Cores 123-766A-44R thorugh -46R (upper portion of susceptibility Unit S-6). High NRM intensities, on the order of $10^{-2} \mathrm{~A} / \mathrm{m}$, are characteristic of the Hauterivian greenishgray sandstone of lithologic Subunit IIIB (susceptibility Unit S-5) and of the basal black siltstones within and overlying volcanic basement (lower portion of susceptibility Unit S-7). Intensities of characteristic magnetization displayed the same stratigraphic variation.

Normal and reversed polarity were generally evident after AF demagnetization at $10 \mathrm{mT}$. Normal polarity samples displayed counterclockwise rotation of apparent declination during progressive AF demagnetization at $2.5,5.0$, and $7.5 \mathrm{mT}$, which probably represents removal of a present-day overprint. Stable directions with decreasing intensity of magnetization were generally observed during progressive demagnetization from 10 through 45 $\mathrm{mT}$. This "linear decay to the origin" in demagnetization plots 
(Fig. 3) represents the characteristic direction of magnetization. This behavior was generally exhibited by all clastic lithologies regardless of color or grain size, and intensities of characteristic magnetization were generally about $30 \%$ to $50 \%$ of NRM intensities. Pilot studies applying thermal demagnetization at $300^{\circ}$ and $400^{\circ} \mathrm{C}$ after the $40-\mathrm{mT}$ treatment displayed no change in direction, but caused a minor decrease in intensity of magnetization.

The correspondence of susceptibility values with intensity of magnetization, coupled with the effective removal of overprints and clear display of polarity zones upon AF demagnetization, implies that most of the magnetization is carried by magnetite. Magnetite has low coercivity, hence, a high response to susceptibility measurements and $\mathrm{AF}$ demagnetization. If high-coercivity hematite or goethite had been an important carrier of magnetization, then neither a quasi-linear relationship of NRM intensity to susceptibility value, nor such a simple display of two-component magnetization upon AF treatments should have been exhibited. Therefore, all samples from the Lower Cretaceous of Site 766 were treated with progressive AF demagnetization to obtain characteristic magnetizations.

\section{PALEOLATITUDES}

\section{Mean Apparent Inclinations}

For each site, mean inclinations relative to the axis of the drill hole were computed from the characteristic magnetization vectors, using the modified method of Kono (1980a, 1980b), as explained previously. Inclinations were computed for different time intervals and for the entire Early Cretaceous sequence. Within each time interval, mean inclinations were calculated for normal- and reversed-polarity separately, for all samples combined, and as a weighted vector mean for $N+R$ (Table 1). The $N$ $+R$ vector sum is considered to be a more realistic approximation to the primary inclination in those cases where the combined-sample case would be dominated by reversed-polarity samples having characteristic inclinations more susceptible to a secondary overprint.

For most sample suites, the mean inclination of the normal-polarity set was nearly antipodal to the mean inclination of the reversed-polarity set. In such cases, we did not find any significant secondary overprint, and the mean inclination calculated as a $N+R$ vector sum did not differ significantly from the mean inclination for all samples combined.

Most sample suites display low dispersion; therefore, $K$ values are typically about 50 . This clustering, plus the large numbers of samples in most sets, results in mean inclinations and corresponding paleolatitudes having typical $95 \%$ confidence limits of about $4^{\circ}$.

\section{Site 765}

Mean inclinations for all intervals fall within a narrow range from $-33^{\circ}$ to $-44^{\circ}$, with the combined suites having inclinations from $-35^{\circ}$ to $-40^{\circ}$.

\section{Site 261}

Despite the low numbers of samples collected from Site 261, the tight clustering of their characteristic inclinations with $K$ s typically 80 or greater yielded mean inclinations of good precision. The mean combined inclinations for the various age intervals range from $-54^{\circ}$ to $-58^{\circ}$.

\section{Site 766}

For all groupings and subgroupings, normal- and reversed-poIarity inclinations were always within about $2^{\circ}$ to $4^{\circ}$ of each other, with narrow circles of confidence $\left(\alpha_{95}\right.$ s typically $2^{\circ}$ to $\left.4^{\circ}\right)$. Therefore, significant secondary overprints may have been removed.
There was no significant change in mean inclination among stages within this Early Cretaceous interval; the mean value (relative to axis of drill hole) is $-51^{\circ} \pm 1^{\circ}$.

\section{Corrected Mean Inclinations and Paleolatitudes}

Holes 766 A and 765C displayed an apparent dip of recovered strata. This apparent dip was generally the same as the measured deviation of the drill hole from vertical; therefore, we presume that this deviation was the only cause of the apparent dips.

Paleomagnetic minicores were collected and oriented with respect to the "up" direction parallel to the drill-core axis, not the stratigraphic "up" direction perpendicular to the strata. Therefore, the mean apparent inclinations of all sample suites from these two sites are relative to the axis of the drill core. To transform these inclinations to values relative to "horizontal bedding," one must rotate the magnetic vectors using the measured dip of bedding and the direction of that bedding with respect to ancient north (Fig. 2). This process will be explained in detail for Hole $766 \mathrm{~A}$, then summarized for Hole $765 \mathrm{C}$.

\section{Correction for Deviation of Hole 766A from Vertical}

The measured in-situ drift of Hole 766A from vertical was $6.5^{\circ}$ at Core 123-766A-27R, and $7.25^{\circ}$ at Cores 123-766A-36R and $-46 R$. These values were similar to shipboard measurements of apparent bedding dips in the recovered cores, and, considering the probable accuracy of the techniques, a constant drift of $7^{\circ} \mathrm{can}$ be assumed for the calculations that follow.

The magnetization of several blocks displaying obvious apparent "dip of bedding" were measured on board the ship. As explained previously, AF demagnetization of these sediments at 10 $\mathrm{mT}$ yielded a characteristic direction that remained stable upon further demagnetization; therefore, the shipboard measurement of directions after $10 \mathrm{mT}$ is considered to represent the direction of ancient north or south. The mean orientation of the "dip plunge" relative to this ancient north was approximately " $\mathrm{N} 40^{\circ} \mathrm{W}$ " $\left( \pm 15^{\circ}\right)$, where measured in normal-polarity intervals.

An apparent plunge toward the northwest in the recovered cores implies that the hole is deviating in this same direction. The direction of "up" orientation of all paleomagnetic minicore samples is parallel to the drill-core axis and was not corrected for the apparent bedding within the sediments. Therefore, the "bedding" correction is equivalent to subtracting (dip-angle $\times$ sin [deviation from ancient north]) from the mean inclination of normal-polarity (hence, ancient north-pointing) samples. The identical value should be added to reversed-polarity (south-pointing) samples. Based on the above data, the bedding correction factor to be subtracted is $7^{\circ} \times \cos \left(40^{\circ}\right)$, or $+4.5^{\circ}$.

Site 766 was in the Southern Hemisphere; hence, normal-polarity inclinations are negative. Therefore, this subtraction results in a steepening of the measured mean inclination. The slight inaccuracies in the measurement of the magnitude and direction of the drift of the hole from vertical were arbitrarily compensated for by increasing the $\alpha_{95}$ confidence limits for the final results by $0.5^{\circ}$. The drift-corrected mean inclination and confidence limits are given in Table 1 .

\section{True Mean Inclination and Paleolatitude of Hole $766 \mathrm{~A}$}

The Early Cretaceous mean inclination for Hole 766A for the vector sum of normal- and reversed-polarity vectors, after correcting for the deviation of the hole from vertical, is $-56.1^{\circ}$. The corrected mean inclination for the combined samples is $-55.7^{\circ}$. These deviation-corrected mean inclinations have $\alpha_{95}$ confidence limits of $2^{\circ}$.

The vector-sum mean inclination corresponds to a mean Early Cretaceous (late Valanginian-Barremian) paleolatitude of $36.6^{\circ} \mathrm{S}$, with a probable $95 \%$ confidence limit of $2.1^{\circ}$. Mean inclinations 
from suites of different ages do not display any significant trends; therefore, the paleolatitude of the site appears to have remained fairly constant throughout this time interval. This lack of change in paleolatitude is particularly apparent when using the preferred method of vector sum computation for mean inclinations.

\section{Correction for Deviation of Hole $765 \mathrm{C}$ from Vertical}

The measured in-situ drift of Hole $765 \mathrm{C}$ from vertical was $10^{\circ}$ at Core 123-765C-45R and $11^{\circ}$ at Core 123-765C-57R. Shipboard cryogenic measurements of the magnetization of recovered strata indicated that the apparent dip of these strata is oriented about $\mathrm{N} 60^{\circ} \mathrm{W}$ with respect to NRM. Unlike the volcaniclastic sediments of Hole $766 \mathrm{~A}$, these reddish claystones of Hole $765 \mathrm{C}$ did not respond to $\mathrm{AF}$ demagnetization, and the NRM is heavily dominated by present-day "north" overprinting. Therefore, the direction of hole deviation is approximately $300^{\circ}\left(\mathrm{N} 60^{\circ} \mathrm{W}\right)$ with respect to present north (Shipboard Scientific Party, 1990b).

All samples from Hole $765 \mathrm{C}$ were oriented relative to the dip direction, thereby permitting a declination control relative for polarity determinations (Fig. 2). Standard statistics were applied to the paleomagnetic directions from each time interval, using a method modified from Fisher (1953), but with inclusion of weighting and dual-polarity vector summation. The resulting mean directions yield the direction of ancient north with respect to the dip direction, hence the direction of the hole deviation required to compute true mean inclination.

Mean directions of ancient north, relative to dip direction, for Hole $765 \mathrm{C}$ are $7^{\circ}$ clockwise for Valanginian-Berriasian, $8^{\circ}$ for Hauterivian, $13^{\circ}$ for Barremian and $23^{\circ}$ for Aptian. These declinations and the corresponding measured drift angles were used to compute the true mean inclinations for each time interval. To compute the mean inclination for the entire set, a $10^{\circ} \mathrm{drift}$ having a $10^{\circ}$ declination relative to ancient north was applied.

\section{True Mean Inclination and Paleolatitude of Hole 765C}

The Early Cretaceous average mean inclination for Hole $765 \mathrm{C}$, after correction for the deviation for the hole, is $-48.4^{\circ}$, with a $95 \%$ confidence limit of $2.4^{\circ}$. This corresponds to a paleolatitude of $29.3^{\circ} \mathrm{S}$. As for Site 766 , there are no statistically significant trends in paleolatitude with time.

The mean inclinations and paleolatitudes of Hole $765 \mathrm{C}$ are considerably shallower than those for the same age at either Site 766 or Site 261 . There are at least two possible factors that could contribute to this apparent shallowing. The first is a shallowing of magnetic inclinations during diagenetic compaction of the more clay-rich strata within this hole; this theoretical "inclination error" will be discussed later. The second factor, and probably the most important, is that the direct shipboard measurements of apparent dips on the recovered cores were up to $15^{\circ}$, and therefore are steeper than the measured $10^{\circ}$ hole deviation and suggest a primary dip is present at this location. Because the magnitude and orientation of the total dip are the important factors for converting apparent inclination to actual inclination relative to ancient horizontal, this would imply that an additional $5^{\circ}$ must be included in the correction factor. If the correction factor of " $15^{\circ} \mathrm{dip}$ at $10^{\circ}$ declination relative to ancient north" is used instead of the hole deviation, then the average mean inclination is $-53.3^{\circ}$, implying a paleolatitude of $33.8^{\circ} \mathrm{N}$. This value is only slightly shallower than the paleolatitudes for the other two sites.

\section{True Mean Inclination and Paleolatitude of Site 261}

No significant apparent dip is present in the strata drilled at Site 261; therefore, it is not necessary to apply any dip corrections. The average mean inclination for the Early Cretaceous is $-56.2^{\circ}$, with a $95 \%$ confidence limit of $3.4^{\circ}$. The corresponding paleolatitude of $36.7^{\circ} \mathrm{S}$ is identical to the paleolatitude for Site 766 .

\section{Rotation of Sites}

During the Cretaceous, Australia was rotated clockwise relative to its present orientation by approximately $30^{\circ}$ to $60^{\circ}$ (e.g., Embleton, 1984; Idnurm, 1985). We were able to observe this rotation in our sample suites by applying two techniques: for Hole $765 \mathrm{C}$, the hole deviation provided a means of measuring actual declination on the minicores; and for Hole 766A, the angular difference between secondary and primary vectors was computed.

The minicores from Hole $765 \mathrm{C}$ had been oriented with respect to the apparent dip of "bedding" in the drill core (Fig. 2). As explained previously, we determined that the resulting dip direction is oriented at approximately $\mathrm{N} 60^{\circ} \mathrm{W}\left( \pm 5^{\circ}\right)$ with respect to present-day north, hence at $300^{\circ}$. The direction of ancient north relative to this hole deviation direction progressively rotates clockwise through time from a difference of $7^{\circ}$ in the BerriasianValanginian to $23^{\circ}$ in the Aptian. The standard deviation confidence limit on each of these relative declinations is approximately $7^{\circ}$. The site experienced a total clockwise rotation of approximately $16^{\circ}$.

Therefore, in present-day coordinates, the direction of ancient north is toward $307^{\circ}$ azimuth for Berriasian-Valanginian, $308^{\circ}$ for Hauterivian, $313^{\circ}$ for Barremian, and $323^{\circ}$ for Aptian. A possible systematic bias of $\pm 5^{\circ}$ exists for this set of declinations and an additional $7^{\circ}$ uncertainity for each individual value.

Vectors of magnetization of normal-polarity samples of Site 766 commonly displayed a counter-clockwise rotation during initial stages of progressive AF demagnetization. This rotation is the result of the removal of a secondary vector, considered to be dominated by present field. The difference in declination between the removed secondary vector, as computed by a least-squares line-fit, and the vector of characteristic magnetization provides a minimum estimate of the net amount of rotation after the Early Cretaceous. A series of close-spaced steps of low AF demagnetization was applied to suites of samples from intervals considered to have normal polarity. The removed vectors displayed considerable variation; several vectors trend in a direction counterclockwise to ancient north, and the majority display inclinations more consistent with Cretaceous paleolatitudes, than with the present latitude of the site. Those that displayed rotation in the expected sense imply a site rotation of about $75^{\circ}\left( \pm 20^{\circ}\right)$.

\section{Comparison to Australian Polar Wander Path}

The Early Cretaceous portion of the Australian polar wander path is poorly constrained. Embleton (1984) interpolated the Early Cretaceous motion of Australia as a smooth arc between two poles of "Oxfordian-Tithonian" and Albian age, derived from intrusives and basalt flows, respectively. Idnurm (1985) incorporates an "Early Cretaceous" pole averaged from 25 sediment samples within the Otway Basin. A set of predicted paleolatitudes and declinations using the "interpolated" polar wander path of Embleton (1984) is presented in Table 2.

Despite their present-day latitude separation of $7^{\circ}$, the predicted Early Cretaceous paleolatitudes for Sites 261 and 766 are similar because of the $45^{\circ}$ rotation of Australia. No significant paleolatitude motion was predicted between the Late Jurassic and the Cenomanian for these sites. Both of these predictions were verified by our paleomagnetic analyses.

These sites should have experienced rapid clockwise rotation during the Early Cretaceous, with a predicted difference of $27^{\circ}$ between the early Berriasian $\left(301^{\circ}\right.$ declination for Site 765$)$ and Albian ( $328^{\circ}$ declination) (Table 2$)$. The observed rotation for Site 765 is nearly identical: $307^{\circ}$ declination in Berriasian-Valanginian vs. $323^{\circ}$ in Aptian, for a net rotation of $16^{\circ}$. If this observed trend continued into the Albian, then there should be at least $25^{\circ}$ of total clockwise rotation between the Berriasian and 
Table 1. Mean inclinations of characteristic magnetization and corresponding paleolatitudes.

\begin{tabular}{|c|c|c|c|c|c|c|c|c|c|}
\hline \multirow{2}{*}{$\begin{array}{l}\text { Site } \\
\text { Age } \\
\text { Polarity }\end{array}$} & \multirow[b]{2}{*}{$\mathrm{N} / \mathrm{Ns}$} & \multicolumn{3}{|c|}{ Mean direction } & \multicolumn{2}{|c|}{ Drift corrected } & \multirow{2}{*}{$\begin{array}{c}\text { Mean } \\
\text { intensity } \\
\left(10^{-3} \mathrm{~A} / \mathrm{m}\right)\end{array}$} & \multicolumn{2}{|c|}{ Paleolatitude } \\
\hline & & $\begin{array}{c}\text { Incl. } \\
\left({ }^{\circ}\right)\end{array}$ & $\alpha_{95 / 63}$ & $\mathrm{~K}$ & $\begin{array}{c}\text { Incl } \\
\left({ }^{\circ}\right)\end{array}$ & $\alpha_{95 / 63}$ & & $\left({ }^{\circ} \mathrm{S}\right)$ & $\alpha_{95 / 63}$ \\
\hline
\end{tabular}

Site 766

Barremian [Cores 123-766A-26 to -31]

\begin{tabular}{|c|c|c|c|c|c|c|c|c|c|}
\hline $\mathrm{N}$ & $10 / 11$ & -52.1 & $4.0 / 2.3$ & 144 & -56.6 & & 23.2 & & \\
\hline $\mathbf{R}$ & $32.5 / 42$ & -45.2 & $3.0 / 1.7$ & 73 & -49.7 & & 2.2 & & \\
\hline Comb. & $42.5 / 53$ & -46.9 & $2.7 / 1.6$ & 66 & -51.4 & $3.2 / 1.9$ & 3.8 & 32.1 & $3.0 / 1.7$ \\
\hline $\mathrm{N}+\mathrm{R}$ & $42.5 / 53$ & -51.4 & & & -55.9 & & 12.7 & 36.5 & \\
\hline \multicolumn{10}{|c|}{ Hauterivian [Cores $123-766 \mathrm{~A}-32$ to -39 ] } \\
\hline $\mathrm{N}$ & $19 / 21$ & -53.1 & $4.5 / 2.6$ & 57 & -57.6 & & 34.3 & & \\
\hline $\mathbf{R}$ & $14.5 / 17$ & -55.7 & $4.8 / 2.8$ & 68 & -60.2 & & 136. & & \\
\hline Comb. & $33.5 / 38$ & -54.2 & $3.3 / 1.9$ & 58 & -58.7 & $3.8 / 2.2$ & 62.2 & 39.5 & $4.2 / 2.4$ \\
\hline $\mathrm{N}+\mathrm{R}$ & $33.5 / 38$ & -55.0 & & & -59.5 & & 85.3 & 40.4 & \\
\hline
\end{tabular}

Combined Hauterivian-Barremian [Cores 123-766A-26 to -39]

\begin{tabular}{|c|c|c|c|c|c|c|c|c|c|}
\hline $\mathrm{N}$ & $29 / 32$ & -52.7 & $3.2 / 1.8$ & 72 & -57.2 & & 30.0 & & \\
\hline $\mathbf{R}$ & $47.5 / 60$ & -48.5 & $3.0 / 1.7$ & 50 & -53.0 & & 7.6 & & \\
\hline $\begin{array}{l}\text { Comb. } \\
\mathrm{N}+\mathrm{R}\end{array}$ & $\begin{array}{l}76.5 / 92 \\
76.5 / 92\end{array}$ & $\begin{array}{l}-50.2 \\
-51.6\end{array}$ & $2.3 / 1.3$ & 51 & $\begin{array}{l}-54.7 \\
-56.1\end{array}$ & $2.8 / 1.6$ & $\begin{array}{l}12.8 \\
18.8\end{array}$ & $\begin{array}{l}35.2 \\
36.7\end{array}$ & $2.8 / 1.6$ \\
\hline
\end{tabular}

Late. Valanginian-Early. Hauterivian [Cores $123-766 \mathrm{~A}-40$ to -49 ]

$\begin{array}{llllllrlll}\mathrm{N} & 36 / 43 & -52.0 & 3.1 / 1.8 & 60 & -56.5 & & 107.0 & \\ \mathrm{R} & 61 / 75 & -51.9 & 2.7 / 1.6 & 46 & -56.4 & & 75.5 & \\ \mathrm{C} & 97 / 118 & -51.9 & 2.0 / 1.2 & 51 & -56.4 & 2.5 / 1.5 & 85.9 & 37.0 & 2.6 / 1.5 \\ \mathrm{~N}+\mathrm{R} & 97 / 118 & -51.9 & & & -56.4 & & 94.3 & 37.0 & \end{array}$

All $=$ L. Valanginian-Barremian $[$ Cores $123-766 \mathrm{~A}-26$ to -49$]$

\begin{tabular}{|c|c|c|c|c|c|c|c|c|c|}
\hline $\mathrm{N}$ & $65 / 75$ & -52.3 & $2.2 / 1.3$ & 64 & -56.8 & & 60.6 & & \\
\hline $\mathrm{R}$ & $109.5 / 136$ & -50.5 & $2.0 / 1.2$ & 46 & -55.0 & & 28.0 & & \\
\hline Comb. & $\begin{array}{l}174.5 / 211 \\
174.5 / 211\end{array}$ & $\begin{array}{l}-51.2 \\
-51.6\end{array}$ & $1.5 / 0.9$ & 50 & $\begin{array}{l}-55.7 \\
-56.1\end{array}$ & $2.0 / 1.2$ & $\begin{array}{l}37.4 \\
44.4\end{array}$ & $\begin{array}{l}36.3 \\
36.6\end{array}$ & $2.1 / 1.2$ \\
\hline
\end{tabular}

Site 261

Barremian [Cores 27-261-21 to -27]

$\begin{array}{lcccc}\mathrm{N} & 12.5 / 13 & -57.9 & 4.8 / 2.8 & 80 \\ \mathrm{R} & 5.5 / 8 & -50.0 & 15.3 / 8.9 & 23 \\ \text { Comb. } & 18 / 21 & -56.3 & 6.4 / 3.7 & 31 \\ \mathrm{~N}+\mathrm{R} & 18 / 21 & -54.2 & & \end{array}$

Valanginian-Hauterivian [Cores 27-261-28 to -29]

$\begin{array}{lcccc}\mathrm{N} & 6 / 6 & -58.4 & 5.4 / 3.1 & 157 \\ \mathrm{R} & 1.5 / 3 & -57.9 & 81.3 / 47.2 & 157 \\ \mathrm{C} & 7.5 / 9 & -58.3 & 4.6 / 2.7 & 157 \\ \mathrm{~N}+\mathrm{R} & 7.5 / 9 & -58.1 & & \end{array}$

Tithonian-Berriasian [Cores 27-261-30 to -32

$\begin{array}{lcccr}\mathrm{N} & 7 / 7 & -52.5 & 3.8 / 2.2 & 259 \\ \mathrm{R} & 6 / 10 & -56.5 & 11.4 / 6.6 & 36 \\ \mathrm{C} & 13 / 17 & -54.3 & 5.0 / 2.9 & 70 \\ \mathrm{~N}+\mathrm{R} & 13 / 17 & -54.9 & & \end{array}$

All = Tithonian-Barremian [Cores 27-261-21 to -32]

$\begin{array}{lcccc}\mathrm{N} & 26.5 / 27 & -56.8 & 2.8 / 1.6 & 99 \\ \mathrm{R} & 13.5 / 22 & -54.3 & 8.1 / 4.7 & 26 \\ \mathrm{C} \text { Comb. } & 40 / 49 & -56.2 & 3.4 / 2.0 & 45 \\ \mathrm{~N}+\mathrm{R} & 40 / 49 & -55.8 & & \end{array}$

the Albian. This close correspondence between predicted and observed rotations is extremely surprising when one considers the probable magnitude of errors associated with the predicted and the observed mean declinations.

Our observations do not support one prediction. After correcting for hole deviation and observed dip of bedding, the average Early Cretaceous mean paleolatitudes for Sites 261 and 765 are about $37^{\circ} \mathrm{S}$. By contrast, the interpolated Early Cretaceous paleo- latitude has been predicted as about $42^{\circ} \mathrm{S}$ ("mid-Hauterivian") for Sites 261 and 765 . Therefore, the predicted paleolatitude is $5^{\circ}$ farther south than the observed. One can debate whether this slight difference results from errors in the interpolated apparent wander path for Australia or to an "inclination shallowing" in the sediments of these sites. The agreement of inclinations derived from the reddish claystone facies of Site 261 with the volcaniclastic turbidite facies of Site 766 suggests that any "inclination error" 
Table 1 (continued).

\begin{tabular}{|c|c|c|c|c|c|c|c|c|c|}
\hline \multirow{2}{*}{$\begin{array}{c}\text { Site } \\
\text { Age } \\
\text { Polarity }\end{array}$} & \multirow[b]{2}{*}{$\mathrm{N} / \mathrm{Ns}$} & \multicolumn{3}{|c|}{ Mean direction } & \multicolumn{2}{|c|}{ Drift corrected } & \multirow{2}{*}{$\begin{array}{c}\text { Mean } \\
\text { intensity } \\
\left(10^{-3} \mathrm{~A} / \mathrm{m}\right)\end{array}$} & \multicolumn{2}{|c|}{ Paleolatitude } \\
\hline & & $\begin{array}{l}\text { Incl. } \\
\left({ }^{\circ}\right)\end{array}$ & $\alpha_{\left({ }^{\circ}\right)}^{\left.\alpha^{\prime}\right)}$ & $\mathbf{K}$ & $\begin{array}{l}\text { Incl } \\
\left({ }^{\circ}\right)\end{array}$ & $\begin{array}{c}\alpha_{95 / 63} \\
\left({ }^{\circ}\right)\end{array}$ & & $\left({ }^{\circ} \mathrm{S}\right)$ & $\underset{\left({ }^{\circ}\right)}{\alpha_{95 / 63}}$ \\
\hline
\end{tabular}

Site 765

Aptian [Cores 123-765C-43 to -48]

$\begin{array}{lccccccccc}\mathrm{N} & 21 / 23 & -40.4 & 4.5 / 2.6 & 51 & & & 4.2 & \\ \mathrm{R} & 3.5 / 5 & -40.3 & 11.3 / 6.8 & 86 & & & 1.7 & & \\ \text { Comb. } & 24.5 / 28 & -40.4 & 4.0 / 2.3 & 54 & -49.6 & 4.5 / 2.6 & 3.7 & 30.4 & 4.0 / 2.3 \\ \mathrm{~N}+\mathrm{R} & 24.5 / 28 & -40.4 & & & & -49.6 & & 3.1 & 30.4\end{array}$

Barremian [Cores 123-765C-49 to -54]

$\begin{array}{lccc}\mathrm{N} & 24.5 / 27 & -38.7 & 4.2 / 2.4 \\ \mathrm{R} & 35 / 43 & -32.4 & 3.3 / 1.9 \\ \text { Comb. } & 59.5 / 70 & -35.1 & 2.7 / 1.6 \\ \mathrm{~N}+\mathrm{R} & 59.5 / 70 & -34.9 & \end{array}$

50
57

47

-44.8
-44.6

Hauterivian [Cores 123-765C-55 to -57]

$\begin{array}{lccc}\mathrm{N} & 8 / 9 & -41.8 & 5.4 / 3.1 \\ \mathrm{R} & 11 / 15 & -33.7 & 6.3 / 3.6\end{array}$

$\mathrm{R} / \mathrm{H} / \mathrm{H}$

$\mathrm{N}+\mathrm{R} \quad 19 / 24 \quad-37.6$

$4.8 / 2.8$
108
54
49
$-47.1$
$-47.5$

$5.3 / 3.1$

$0 / 2.3$

Berriasian-Valanginian [Cores 123-765C-58 to -62]

$\begin{array}{lcccr}\mathrm{N} & 37.5 / 42 & -43.9 & 2.3 / 1.4 & 102 \\ \mathrm{R} & 16 / 23 & -34.9 & 9.5 / 5.5 & 16 \\ \text { Comb. } & 53.5 / 65 & -41.8 & 3.8 / 2.2 & 27\end{array}$

$\begin{array}{lll}\mathrm{N}+\mathrm{R} & 53.5 / 65 & -40.5\end{array}$

$3.8 / 2.2$

27

$-52.7$

$-51.4$

$4.3 / 2.5$

All = Berriasian-Aptian [Cores $123-765 C-43$ to -62$]$

\begin{tabular}{|c|c|c|c|c|c|c|c|c|c|}
\hline$N$ & $94 / 104$ & -41.6 & $1.9 / 1.1$ & 61 & & & 4.6 & & \\
\hline $\mathbf{R}$ & $65.5 / 86$ & -33.6 & $3.0 / 1.7$ & 35 & & & 2.9 & & \\
\hline Comb. & $159.5 / 190$ & -38.5 & $1.9 / 1.1$ & 36 & -48.4 & $2.4 / 1.4$ & 3.8 & 29.3 & $2.1 / 1.2$ \\
\hline$N+R$ & $159.5 / 190$ & -36.6 & & & -46.5 & & 3.7 & 27.7 & \\
\hline
\end{tabular}

Polarity sets: $N, R=$ Normal- or Reversed-polarity sample set, respectively. Comb. $=$ All samples combined. $N+R=$ Vector sum of the mean normal- and the reversed-polarity vectors of direction and intensity. Confidence limits on $N+R$ are probably similar to Comb. N/Ns: $\mathrm{N}=$ effective number of samples used in calculation after giving half-weight to samples having poor stability (see text). Ns = number of selected samples (questionable and indeterminant polarity samples omitted). If there was no weighting necessary, then $\mathrm{N}=\mathrm{Ns}$. Mean Direction: Mean inclination (and precision parameters) of sample suite using method of Kono (1980a, 1980b), $\alpha_{95 / 63}=95 \%$ and $63 \%$ confidence limits about mean inclination. $K=$ dispersion parameter. Drift Corrected: Mean inclination corrected for deviation angle and direction of the drill hole from vertical. $95 \%$ and $63 \%$ confidence limits $\left(\alpha_{95 / 63}\right)$ are also recomputed. Mean intensity is logarithmic mean of the intensities of characteristic magnetization of the selected sample set. Paleolatitude = Location of site (south of equator) computed for the specified time interval. Confidence limits of $95 \%$ and $63 \%$ are also given. The paleolatitude value in bold type is considered to be the most representative for this suite; generally the Comb. result is selected. However, the vector sum, $N+R$, is considered to be a more valid representation of the characteristic inclination and corresponding paleolatitude if (1) the suite has more reversed-polarity samples than normal-polarity ones and (2) the reversed-polarity mean inclination was relatively non-antipodal to the normal-polarity inclination (see text).

must be facies independent. Therefore, it seems more likely that the main difficulty is the lack of constraints on the current Australian polar wander path.

After correcting for observed dip of bedding, the average Early Cretaceous paleolatitude of Site 765 is about $34^{\circ}$, or $3^{\circ}$ north of Sites 261 and 766 . In contast, Site 765 was predicted as about $2^{\circ}$ to the south of these sites. This $5^{\circ}$ error in relative paleolatitude must represent a bias with the final results from Site 765 . The presence of observed dips of strata that exceed the measured hole deviation suggests the possibilities that the actual dip of strata in the hole is much greater (by the required $5^{\circ}$ ?) and that the hole deviation from vertical reduced the actual dip. The tendency of drill holes to bend perpendicular to dipping strata supports this hypothesis.

In summary, the paleomagnetic results verify the orientation and the clockwise $15^{\circ}$ to $20^{\circ}$ rotation of these sites through the Early Cretaceous. No significant paleolatitude drift accompanied this rotation. The average paleolatitude for these sites was $37^{\circ} \mathrm{S}$ $\left( \pm 2^{\circ}\right)$.

Projection of these Leg 123 paleolatitudes and rotations upon a reconstruction of the Gondwanaland landmass enables one to determine the paleogeography of the former supercontinent. A Berriasian-early Valanginian paleogeography for Australia-Antarctica-India is illustrated in Figure 4 using the reconstruction parameters of Royer and Sandwell (1989) for closure of Australia and Antarctica and of Powell et al. (1988) for closure of India and Antarctica and the paleomagnetic pole projected by the $307^{\circ}$ declination and $37^{\circ}$ paleolatitude of the Leg 123 sites.

\section{MAGNETOSTRATIGRAPHY AND ASSIGNMENT OF POLARITY CHRONS}

A stratigraphic plot was prepared for each site that displayed depth, core recover, lithologic units, biostratigraphic ages, inclination and intensity of characteristic magnetization, and interpre- 
Table 2. Predicted paleolatitudes and declinations for Sites 765, 766, and 261.

\begin{tabular}{|c|c|c|c|c|c|c|}
\hline \multirow{2}{*}{$\begin{array}{c}\text { Age } \\
\left.\text { (S. Pole position, }{ }^{\circ} \mathrm{S},{ }^{\circ} \mathrm{E}\right)\end{array}$} & \multicolumn{2}{|c|}{$\begin{array}{c}\text { Site } 765 \\
\left(16.0^{\circ} \mathrm{S}, 117.6^{\circ} \mathrm{E}\right)\end{array}$} & \multicolumn{2}{|c|}{$\begin{array}{c}\text { Site } 261 \\
\left(12.9^{\circ} \mathrm{S}, 117.9^{\circ} \mathrm{E}\right)\end{array}$} & \multicolumn{2}{|c|}{$\begin{array}{c}\text { Site } 766 \\
\left(19.9^{\circ} \mathrm{S}, 110.5^{\circ} \mathrm{E}\right)\end{array}$} \\
\hline & $\begin{array}{l}\text { Lat. } \\
\left({ }^{\circ} \mathrm{S}\right)\end{array}$ & $\begin{array}{l}\text { Decl. } \\
\left({ }^{\circ} \mathrm{E}\right)\end{array}$ & $\begin{array}{l}\text { Lat. } \\
\left({ }^{\circ} \mathrm{S}\right)\end{array}$ & $\begin{array}{l}\text { Decl. } \\
\left({ }^{\circ} \mathrm{E}\right)\end{array}$ & $\begin{array}{l}\text { Lat. } \\
\left({ }^{\circ} \mathrm{S}\right)\end{array}$ & $\begin{array}{l}\text { Decl. } \\
\left({ }^{\circ} \mathrm{E}\right)\end{array}$ \\
\hline \multicolumn{7}{|l|}{ early Miocene ( $20 \mathrm{Ma})$} \\
\hline$(77,120)$ & 29.0 & 359.4 & 25.9 & 359.5 & 32.7 & 357.5 \\
\hline \multicolumn{7}{|l|}{ Eocene/Paleocene ( $58 \mathrm{Ma})$} \\
\hline$(62,118)$ & 44.0 & 359.7 & 41.0 & 359.9 & 47.6 & 354.8 \\
\hline \multicolumn{7}{|l|}{ Campanian (80 Ma) } \\
\hline$(51,134)$ & 52.6 & 343.0 & 49.8 & 344.0 & 53.8 & 334.8 \\
\hline \multicolumn{7}{|l|}{ Cenomanian/Turonian ( $90 \mathrm{Ma})$} \\
\hline$(55,147)$ & 44.9 & 336.6 & 42.2 & 337.9 & 45.4 & 330.9 \\
\hline \multicolumn{7}{|l|}{ Albian (105 Ma) } \\
\hline$(53,158)$ & 41.3 & 328.7 & 38.9 & 330.1 & 40.8 & 324.1 \\
\hline \multicolumn{7}{|l|}{ mid-Hauterivian (115 Ma) } \\
\hline$(42,149)$ & 44.7 & 314.1 & 42.7 & 316.2 & 42.2 & 309.2 \\
\hline \multicolumn{7}{|l|}{ earliest Berriasian (128 Ma) } \\
\hline$(33,162)$ & 45.6 & 301.4 & 45.2 & 304.1 & 42.5 & 297.0 \\
\hline \multicolumn{7}{|l|}{ Oxfordian-Tithonian (150-170 Ma) } \\
\hline$(20,164)$ & 45.8 & 282.4 & 45.4 & 285.5 & 39.9 & 279.9 \\
\hline \multicolumn{7}{|l|}{ Sinemurian-Bathonian (160-190 Ma) } \\
\hline$(51,182)$ & 28.4 & 319.8 & 26.2 & 320.9 & 26.9 & 318.0 \\
\hline \multicolumn{7}{|l|}{ early Triassic-Anisian (240 Ma) } \\
\hline$(30,147)$ & 60.0 & 302.7 & 58.2 & 307.0 & 55.5 & 294.3 \\
\hline
\end{tabular}

Paleopositions and rotations of the sites are computed from the Australian apparent polar wander path of Embleton (1984), in turn based on Embleton (1981) and Embleton and McElhinny (1982), with his interpolated poles shown in italics. Exceptions are the "early Miocene" and "Eocene/Paleocene," which incorporate later paleomagnetic data from Idnurm (1985). Idnurm's "Lower Cretaceous" pole has not been used due to its uncertain age and few samples. Most poles for the Cretaceous and Tertiary and for the Sinemurian-Bathonian have $95 \%$ confidence circles of $4^{\circ}-6^{\circ}$; poles for the Triassic and rest of Jurassic have about $10^{\circ}$ uncertainties. Geologic stages have been assigned from Embleton's Ma ages, using his original time scale, to compare with geologic stages of Leg 123.

tation of polarity zones (Figs. 5, 6, and 7). For Site 765, declination of characteristic magnetization relative to apparent dip direction of strata was also plotted stratigraphically (Fig. 5).

\section{Site 765}

\section{Aptian Polarity Chrons}

Two reversed-polarity zones appear within Aptian lithologic Subunit VB at the base of an extended zone of normal polarity, which corresponds to the Cretaceous "Quiet Zone" (Fig. 5). The lower reversed-polarity zone (top of Core $123-765 \mathrm{C}-47 \mathrm{R}$ to Section $123-765 \mathrm{C}-47 \mathrm{R}-4,66 \mathrm{~cm}$ ) is slightly younger than the Barremian/Aptian boundary. This corresponds in age to reversedpolarity chron M0r, which is slightly younger than the nannofossil-defined Barremian/Aptian boundary in Atlantic-Tethyan magnetobiostratigraphic sections (Ogg, 1988). The upper limit of polarity zone M0r is not constrained in Hole $765 \mathrm{C}$ because of poor recovery. If sedimentation rates were relatively constant, then the identification of M0r might constrain the Barremian/Aptian boundary to fall within basal Core $123-765 \mathrm{C}-47 \mathrm{R}$ or within uppermost $-48 R$.
The highest reversed-polarity zone is a narrow, but clearly defined, event spanning only $43 \mathrm{~cm}$ in the detailed shipboard analyses (Samples 123-765C-43R-2, $114 \mathrm{~cm}$, to $-43 \mathrm{R}-3,7 \mathrm{~cm}$ ). A brief late Aptian or early Albian event has been noted in magnetostratigaphic studies in Europe (Pechersky and Khramov, 1973; Vandenberg et al., 1978; Vandenberg and Wonders, 1980; Lowrie et al., 1980) and in DSDP sites in the Atlantic (Keating and Helsley, 1987a,b), Indian Ocean (Jarrard, 1974), and Pacific (Tarduno et al., 1989). In magneto-biostratigraphic sections, the age of this brief reversed-polarity chron is late Aptian, within the $G$. algerianus foraminiferal zone (Vandenberg and Wonders, 1980; Tarduno et al., 1989). A narrow magnetic anomaly also may correspond to this reversed-polarity zone (e.g., Vogt and Einwich, 1979). The preferred nomenclature is $M^{\prime \prime}-1 " r$, implying the next younger polarity chron to M0 (e.g., Shipboard Scientific Party, 1986), although "ISEA reversal" has also been used (e.g., Tarduno et al., 1989). This M"-1"r reversed-polarity chron is also near the Selli event of an expanded oxygen minimum in the global oceans (Thurow, pers. comm., 1989, and in press.). The identification of M"- 1 " $r$ within Site 765 adds another well-documented occurrence to this brief event in the late Aptian. 


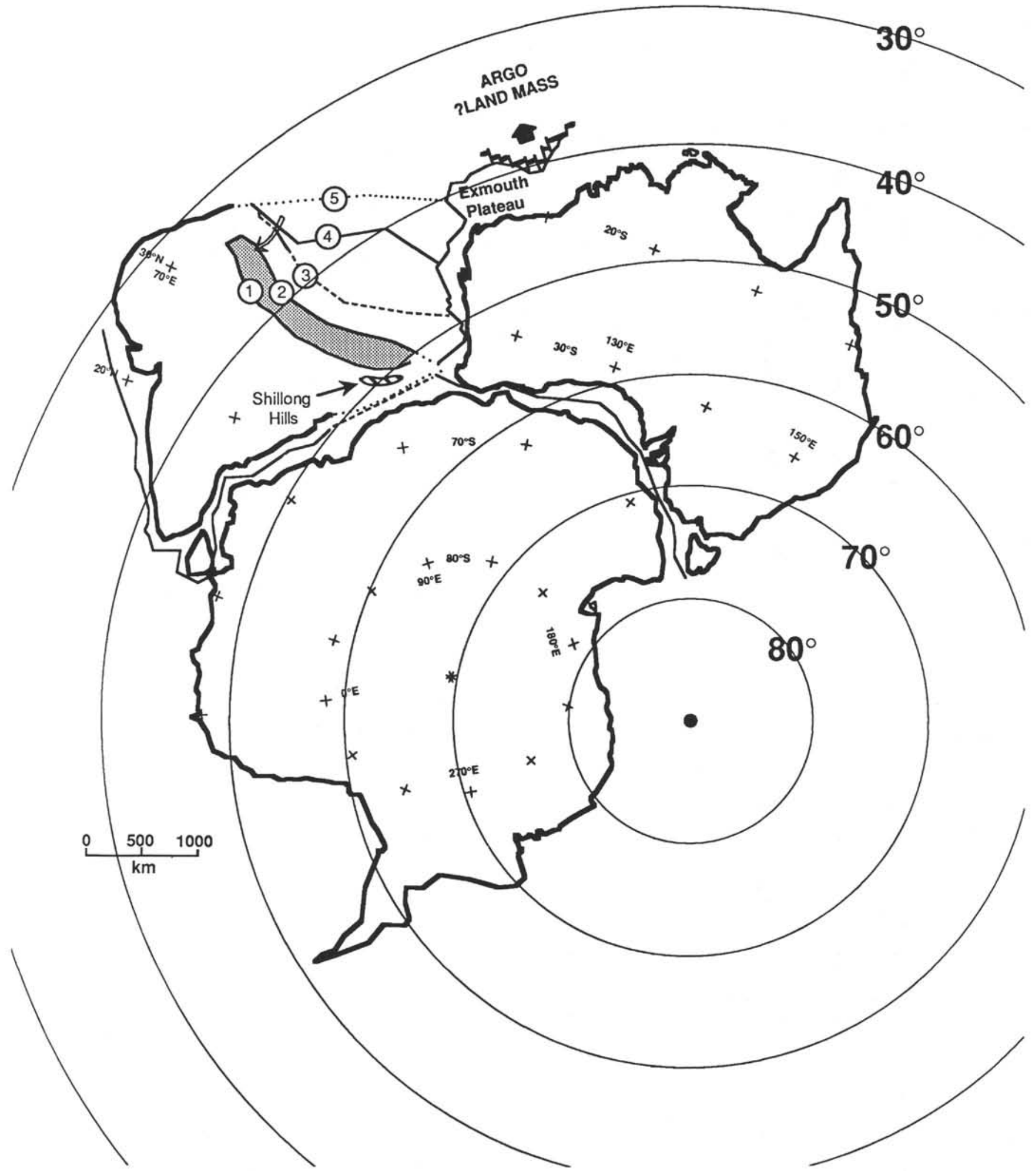

Figure 4. Berriasian-early Valanginian paleogeography and paleolatitudes prior to the separation of India from Australia-Antarctica. Rotation of Antarctica relative to Australia is $31.50^{\circ}$ about a pole at $2.0^{\circ} \mathrm{S}, 38.9^{\circ} \mathrm{E}$ (Royer and Sandwell, 1989); rotation of India relative to Antarctica is $-92.45^{\circ}$ about a pole at $4.22^{\circ} \mathrm{S}, 17.14^{\circ} \mathrm{E}$ (Powell et al., 1988). In India, the Shillong Hills indicate the minimum eastward extinct of India; the Himalayas (shaded region) lie between the Main Boundary Fault (1) and the Indus-Tsangpo Suture (2); Line 3 is the minimum northward extent of India after unwinding the doubled thickness of crust south of the Indus-Tsangpo Suture; Line 4 is the Kun Lun-southern Tsaidam mountain front; and Line 5 is the postulated northern edge of Greater India (from Powell et al., 1988). South Pole location and corresponding paleolatitude grid are based upon the BerriasianValanginian mean paleolatitude of $37^{\circ} \mathrm{S}$ and declination of $307^{\circ}$ for the Leg 123 sites. 


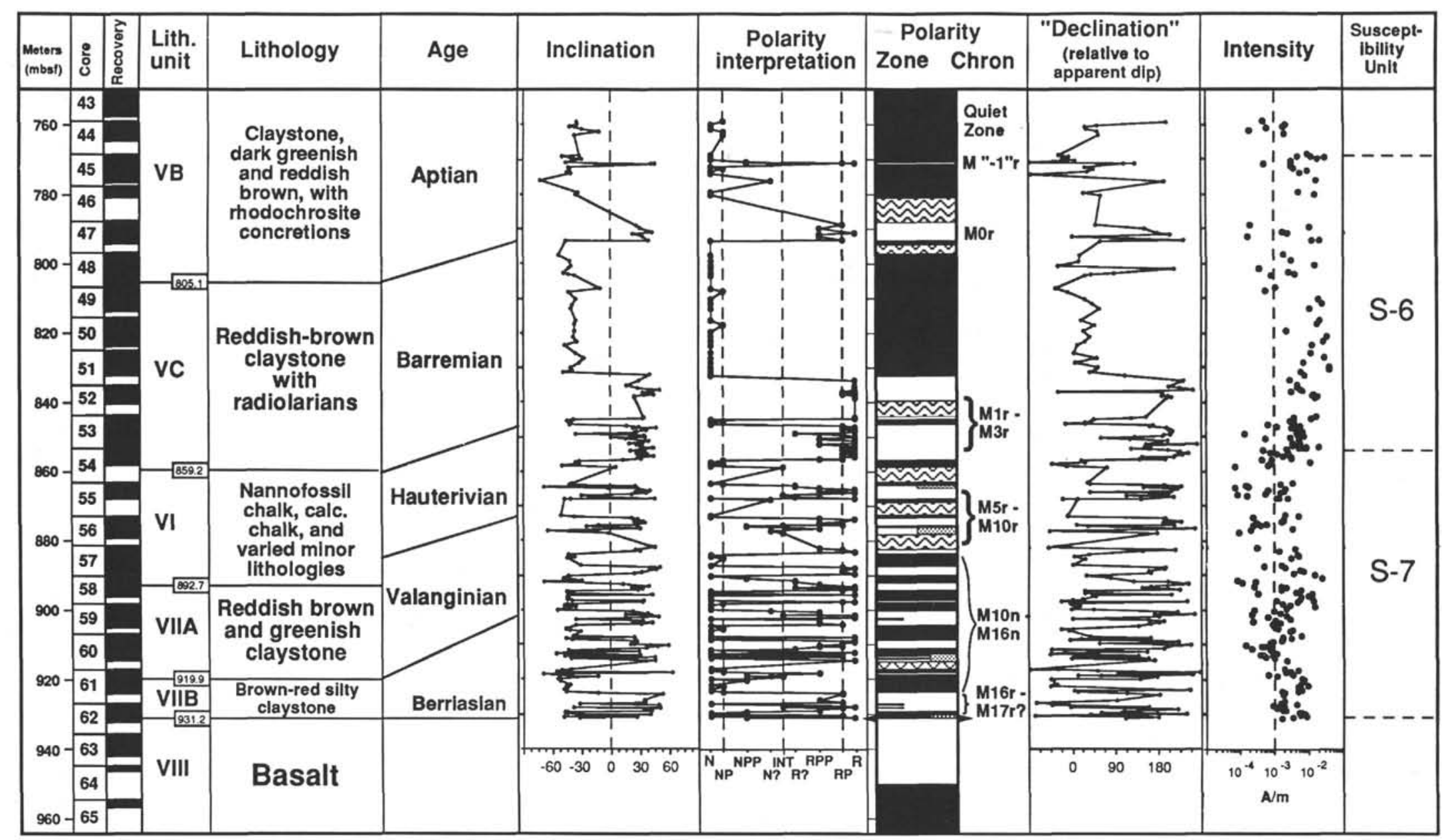

Figure 5. Lower Cretaceous magnetostratigraphy of Hole 765C. Polarity interpretations are given as N-NP-NPP-N?-INT-R?-RPP-RP-R, as explained in the text, and converted to a standard polarity diagram $($ black $=$ normal polarity, white $=$ reversed polarity, gray $=$ uncertain polarity, wavy pattern $=$ gap in sampling, short bars $=$ single sample with polarity interpretation opposite adjacent samples). 


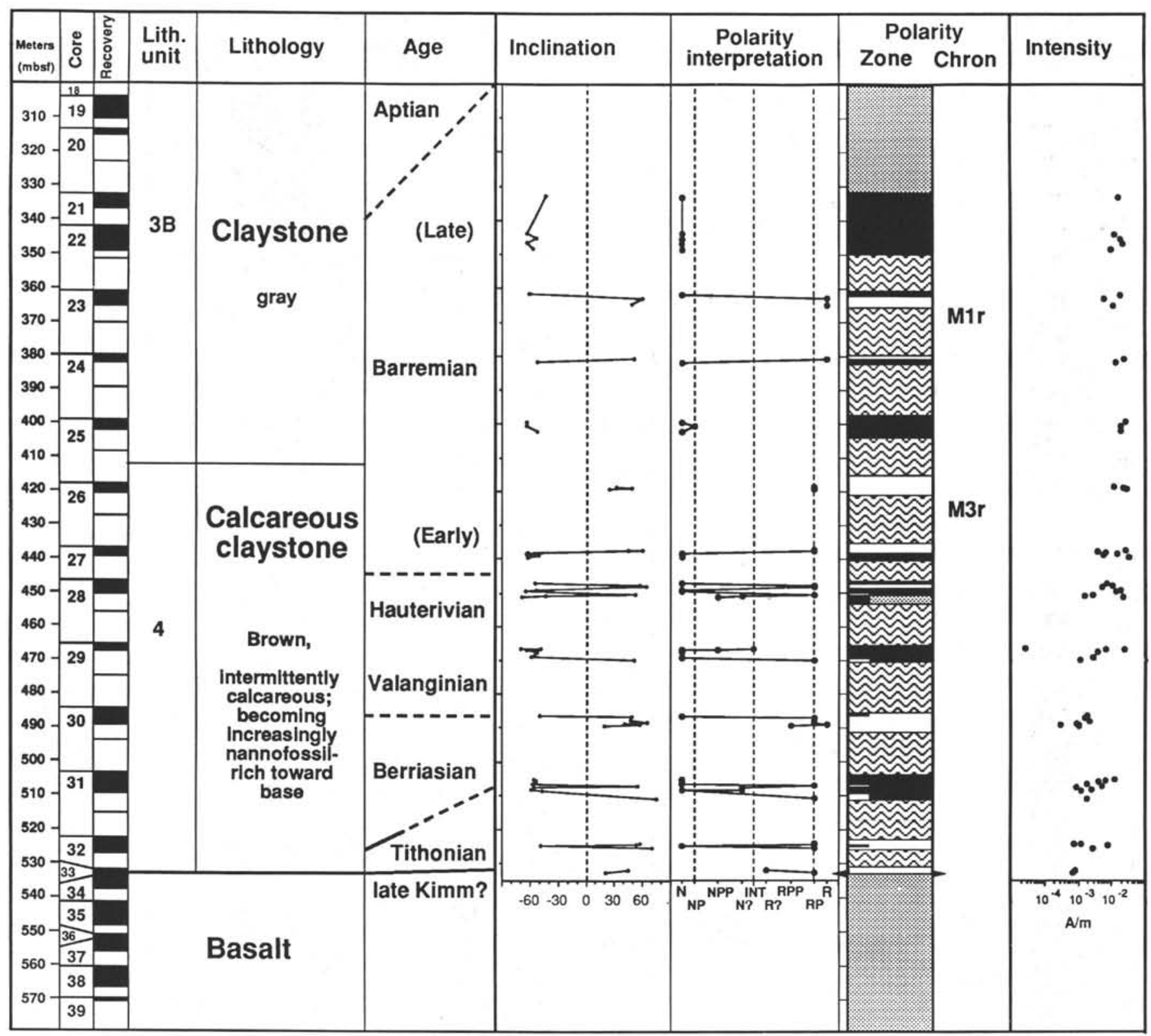

Figure 6. Lower Cretaceous magnetostratigraphy of Site 261. Polarity interpretations are given as N-NP-NPP-N?-INT-R?-RPP-RP-R, as explained in the text, and converted to a standard polarity diagram (black $=$ normal polarity, white $=$ reversed polarity, gray $=$ uncertain polarity, wavy pattern $=$ gap in sampling, short bars = single sample with polarity interpretation opposite adjacent samples).

\section{Barremian Polarity Chrons}

The lower Barremian is reversed polarity with a narrow normal-polarity zone in the center. This interval is assigned to reversed-polarity chron $\mathrm{M} 3 \mathrm{r}$, which encompasses most of the early Barremian. It is possible that reversed-polarity chron $\mathrm{M} 1 \mathrm{r}$, of mid-Barremian age, comprises the upper reversed-polarity zone. Alternatively, reversed-polarity zone $\mathrm{M} 3 \mathrm{r}$ in some magnetostratigraphic sections has been observed to incorporate brief normal-polarity zones (J.E.T. Channell, pers. comm., 1989).

\section{Hauterivian-Valanginian-Berriasian Polarity Chrons}

Below polarity zone $\mathrm{M} 3 \mathrm{r}$ in Hole $765 \mathrm{C}$ are at least 12 distinct reversed-polarity zones, and probably several less well-defined zones. The combination of slow sedimentation rates and possible hiatuses, of incomplete recovery and of lack of precise biostratigraphic datums renders assignment of polarity chrons difficult. It is interesting to note that the late Berriasian through Hauterivian portion of the magnetic polarity time scale also has 12 main polarity chrons with several lesser chrons, however this polaritychron pattern is not distinctive and does not resemble the polarity-zone pattern of Hole $765 \mathrm{C}$.

Tentatively, we suggest that (1) the dominance of reversed polarity in Hauterivian Cores $123-765 \mathrm{C}-55 \mathrm{R}$ and -56R corresponds to the reversed-polarity-rich cluster of polarity chrons M5r through M10r; (2) the dominance of normal polarity in Valanginian Cores $123-765 \mathrm{C}-57 \mathrm{R}$ through $-61 \mathrm{R}$ corresponds to the normal-polarity-rich combination of polarity chrons $\mathrm{M} 10 \mathrm{~N}$ through M16n; and (3) the dominance of reversed polarity in Core 123-765C-62 of Berriasian age may be within the reversed-polarity-rich cluster of M16r through M18r. 


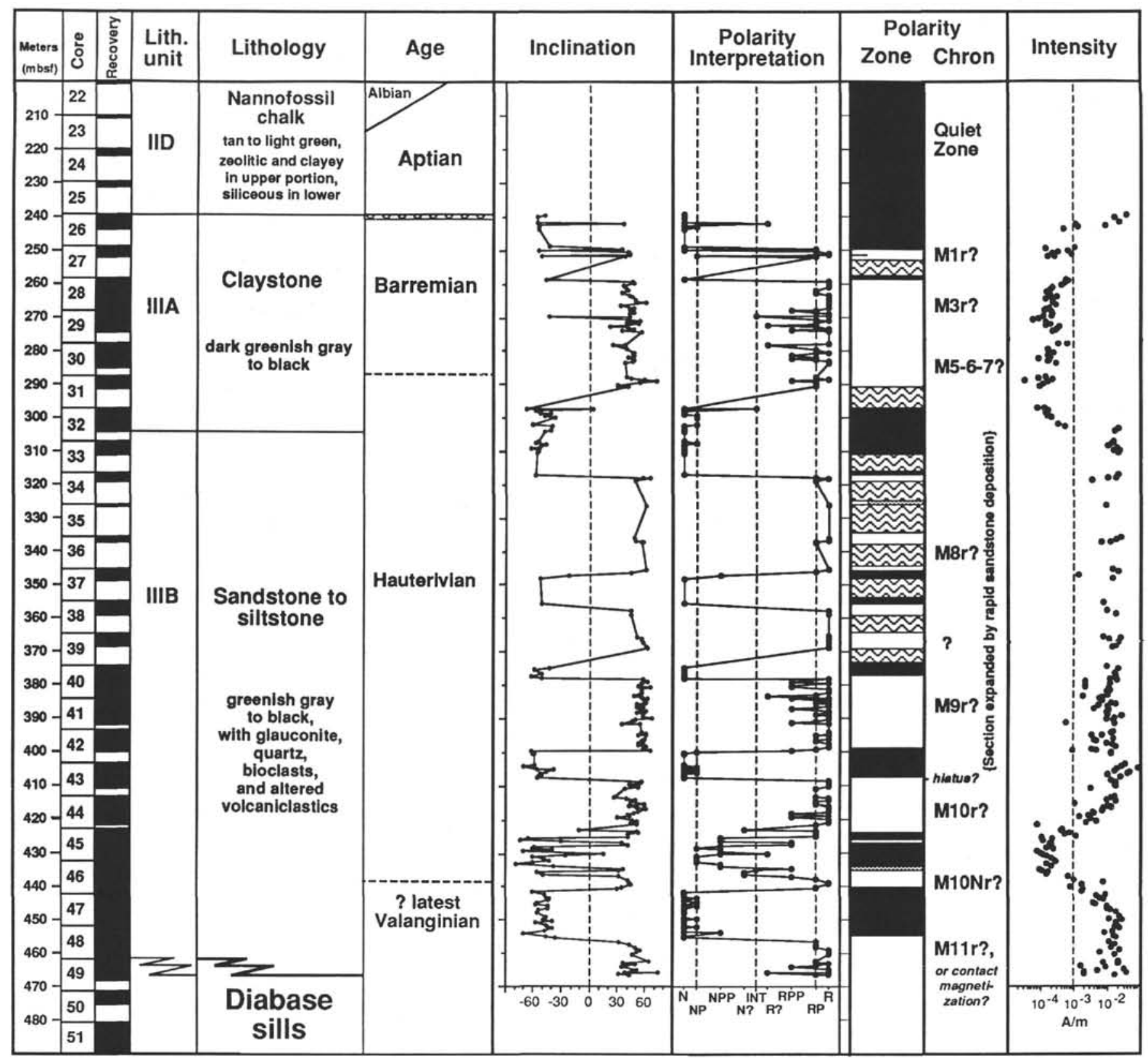

Figure 7. Lower Cretaceous magnetostratigraphy of Hole 766A. Polarity interpretations are given as N-NP-NPP-N?-INT-R?-RPP-RP-R, as explained in the text, and converted to a standard polarity diagram (black $=$ normal polarity, white $=$ reversed polarity, gray $=$ uncertain polarity, wavy pattern $=$ gap in sampling, short bars = single sample with polarity interpretation opposite adjacent samples).

The underlying basaltic crust has reversed polarity in the upper portion, but normal polarity in the lowermost core (Shipboard Scientific Party, 1990).

\section{Site 261}

The sample suite from Site 261 yielded clear polarity determinations; however, the discontinuous coring of this site creates a patchwork of polarity zones separated by large gaps (Fig. 6). The revised biostratigraphy (Dumoulin and Bown, this volume) indicates the probable presence of thick reversed-polarity zones M1r and $\mathrm{M} 3 \mathrm{r}$ in the lower and middle Barremian. Underlying polarity zones are too incomplete to allow polarity chron assignments.
One can use the Barremian magnetostratigraphy of Sites 765 and 261 to assign correlation horizons to these Argo Abyssal Plain sites. The base of reversed-polarity chron M3r was observed in the middle of Core 27-261-27R and in the middle of Core 123$765 \mathrm{C}-54 \mathrm{R}$, a level that is just above a narrow upward transition from brownish-red claystone to dark gray claystone at both sites (Dumoulin and Bown, this volume). The top of reversed-polarity zone M1r, if properly identified in both sites, implies that the middle of Core 27-261-22R corresponds to the base of 123-765C$51 \mathrm{R}$. The sediment thickness between these two horizons is about $75 \mathrm{~m}$ at Site 261 , but only $25 \mathrm{~m}$ at Site 765 . This relatively expanded Barremian section at Site 261 is consistent with the biostratigraphy, although this is slightly circular logic, because 
these polarity chrons are assigned according to the biostratigraphic control.

\section{Site 766}

Site 766 has an expanded Early Cretaceous section and broad polarity zones (Fig. 7). The main age constraints on identification of polarity zones and on assignment of the corresponding polarity chrons are

1. The base of the sediment section above basaltic basement should have an age of polarity chron M10N or slightly older-the age of initiation of seafloor spreading as determined from magnetic anomaly signatures in the immediately adjacent Gascoyne Abyssal Plain (Fullerton et al., 1989). This constraint is supported by the latest Valanginian age assigned to the basal sediments from biostratigraphy (Shipboard Scientific Party, 1990b). Reversed polarity in the basal sediments and intercalated basalts is therefore interpreted as M11r.

2. A major contact occurs between Barremian clayey quartz sandstone with glauconite and Aptian nannofossil chalk at the top of Core 123-766A-26R. It is probable that a major hiatus represents the late Barremian and/or early Aptian.

These ages constrain assignment of magnetic chrons to fall between chron M1 (late Barremian) and M11 (latest Valanginian).

\section{Barremian Polarity Chrons}

The facies boundary from abundant glauconitic sandstone turbidites to overlying dark bioturbated claystone (boundary of lithologic Subunits IIIA and IIIB within Core 123-766A-32R) corresponds to a sudden change in mean magnetic intensity (Fig. 7) and possibly to a minor hiatus related to a local transgression. This boundary is approximately at the Hauterivian/Barremian age boundary, although exact identification of this stage boundary by nannofossils or dinoflagellates is difficult (Ogg, 1988). The thick reversed-polarity zone in the Barremian claystones has been assigned to the relatively long polarity chron $\mathrm{M} 3 \mathrm{r}$ of middle Barremian age.

Cores 123-766A-28R and uppermost -29R display another poorly defined reversed-polarity zone that is separated from zone $\mathrm{M} 3 \mathrm{r}$ by a narrow normal-polarity interval. This might represent either the reversed-polarity chron M1r or a subchron within M3r, as observed in some Italian magnetostratigraphic sections (J.E.T. Channell, pers. comm., 1989) and in Atlantic DSDP Sites (Ogg, 1987).

\section{Hauterivian Polarity Chrons}

The interval encompassing Cores 123-766A-43R through $-33 R$ consists almost entirely of bioturbated sandstone interbedded with coarse sandstone turbidites (especially abundant below the lower portion of Core 123-766A-37R) and represents an accelerated and fluctuating sedimentation rate. Despite the low recovery in the upper portion of this unit, the three pairs of normal- and reversed-polarity zones possibly are an accurate representation of the polarity structure. However, the apparent hiatuses or condensation intervals that bound this sandstone unit and the probable distortion of its polarity pattern preclude reliable assignment of polarity chrons. Possible polarity chrons M9?, M8? and M7? have been tentatively assigned, based solely on the constraints placed by the polarity structure of the overlying and underlying lithologic units.

A sharp facies change in lowermost Core 123-766A-43R from medium-bedded sandstone turbidites to an underlying unit of homogeneous, bioturbated, very dark siltstone corresponds to a boundary between normal- and reversed-polarity zones; therefore, a minor hiatus should be expected. This homogeneous bio- turbated siltstone is assumed to have had a relatively constant sedimentation rate, as compared to the turbidite-rich overlying unit and an age spanning the Valanginian/Hauterivian boundary. Therefore, the polarity-zone pattern was assigned to polarity chrons M11r-M10Nr-M10r, which display a similar general pattern within this same age interval.

However, note that this polarity-zone pattern also resembles that of polarity chrons M12r-M11Ar-M11r of late Valanginian age. This alternative assignment should permit the overlying sandstone unit to encompass polarity chrons M10r-M9r-M8r. Such ambiguity in polarity-chron assignment can perhaps be resolved in the future with improved Hauterivian-Valanginian biostratigraphy, both in Hole $766 \mathrm{~A}$ and in calibration of the standard magnetic polarity time scale.

\section{SUMMARY}

Paleolatitude of the Argo and Gascoyne abyssal plains remained steady at $37^{\circ} \mathrm{S}\left( \pm 2^{\circ}\right)$ from the Berriasian through the Aptian. During this period, this region displayed a clockwise rotation of about $16^{\circ}$ from a Berriasian orientation of $307^{\circ}$ relative to present position (Fig. 4) to an Aptian declination of $323^{\circ}$. These declination values have a systematic uncertainty of about $5 \mathrm{~m}$ as a result of inaccuracy when determining hole deviation of Hole $765 \mathrm{C}$. Individual declinations have uncertainities of about $7^{\circ}$ because of dispersion of sample declination values.

The stable paleolatitude and the absolute and relative amounts of site rotation agree with the interpolated Early Cretaceous apparent polar wander path for Australia, but the paleolatitudes imply a position $5^{\circ}$ north of the predicted location. This set of paleolatitudes represents the first well-dated controls on the Early Cretaceous portion of the Australian polar wander path.

Polarity zones are easily determined for each of the three sites; however, the combination of incomplete recovery, uncertain biostratigraphic control, and slow sedimentation rates precludes assignment of polarity chrons for most of the Berriasian through Hauterivian. Barremian polarity chrons M1r and M3r are present at each site. Earliest Aptian reversed-polarity chron M0r is present at Site 765. The brief reversed-polarity chron M"-1" $r$ of mid-Aptian or late Aptian age was identified at Site 765 .

\section{ACKNOWLEDGMENTS}

We thank the Ocean Drilling Program for inviting our participation during Leg 123. This paleomagnetic study would not have been possible without the constant uninhibited interchange of observations and preliminary results with our shipboard colleagues. The paleomagnetic analyses and interpretations were supported by a grant from the U.S. Science Support Program (J.O.) and by the Japan Ocean Drilling Program (K.K.). We thank the paleomagnetic laboratories at Caltech (under Joseph Kirschvink) and University of Wyoming (under Peter Shive and Maureen Steiner) for allowing us to use their facilities, and Marie Bowyer and Sashiko for performing the measurements at Kochi University. An early manuscript benefited greatly from reviews by J. J. Veevers, F. M. Gradstein, and an anonymous reviewer.

\section{REFERENCES}

Bralower, T. J., 1987. Valanginian to Aptian calcareous nannofossil stratigraphy and correlation with the upper M-sequence magnetic anomalies. Mar. Micropaleontol., 11:293-310.

Bralower, T. J., Monechi, S., and Thierstein, H. R., 1989. Calcareous nannofossil zonation of the Jurassic-Cretaceous boundary interval and correlation with the geomagnetic polarity timescale. Mar. Micropaleontol., 14:153-235.

Channell, J.E.T., Bralower, T. J., and Grandesso, P., 1987. Biostratigraphic correlation of M-sequence polarity chrons M1 to M22 at Capriolo and Xausa (S. Alps, Italy). Earth Planet. Sci. Lett., 58:189201. 
Channell, J.E.T., and Grandesso, P., 1987. A revised correlation of magnetozones and calpionellid zones based on data from Italian pelagic limestone sections. Earth Planet. Sci. Lett., 85:222-240.

Channell, J.E.T., Lowrie, W., and Medizza, R., 1979. Middle and Early Cretaceous magnetic stratigraphy from the Cismon section, northern Italy. Earth Planet. Sci. Lett., 42:153-166.

Embleton, B.J.J., 1981. A review of the palaeomagnetism of Australia and Antarctica. In McElhinny, M. W., and Valencio, D. A., Paleoreconstruction of the Continents. Am. Geophys. Union Geodynamics Ser., 2:77-92.

1984. Continental paleomagnetism. In Veevers, J.J., (Ed.), Phanerozoic Earth History of Australia: Oxford (Oxford University Press), 11-16.

Embleton, B.J.J., and McElhinny, M. W., 1982. Marine magnetic anomalies, paleomagnetism and the drift history of Gondwanaland. Earth Planet. Sci. Lett., 58:141-150.

Fisher, R. A., 1953. Dispersion on a sphere. Proc. R. Soc. London, A217:295-305.

Fullerton, L. G., Sager, W. W., and Handschumacher, D. W., 1989. Late Jurassic-Early Cretaceous evolution of the eastern Indian Ocean adjacent to Northwest Australia. J. Geophys. Res., 94:2937-2953.

Galbrun, B. 1984. Magnetostratigraphie de la limite Jurassique-Cretace. Proposition d'une echelle de polarité à partir du stratotype du Berriasien (Berrias, Ardeche, France) et de la Sierra de Lugar (Province de Murcie, Espagne) [these troisieme cycle]. Univ. Pierre et Marie Curie, Paris, Mem. Sci. Terre, 38.

1985. Magnetostratigraphy of the Berriasian stratotype section (Berrias, France). Earth Planet. Sci. Lett., 74:130-136.

Harland, W. B., Cox, A. V., Llewellyn, P. G., Picton, C.A.G., Smith, A. G., and Walters, R., 1982. A Geologic Time Scale: Cambridge (Cambridge Univ. Press).

Idnurm, M., 1985. Late Mesozoic and Cenozoic palaeomagnetism of Australia - I. A redetermined apparent polar wander path. Geophys. J. R. Astro. Soc., 83:399-418.

Jarrard, R. D., 1974. Paleomagnetism of some Leg 27 sediment cores. In Veevers, J. J., Heirtzler, J. R., et al., Init. Repts. DSDP, 27: Washington (U.S. Govt. Printing Office), 415-423.

Keating, B. H., and Helsley, C. E., 1978a. Magnetostratigraphic studies of Cretaceous sediments from DSDP Site 369. In Lancelot, Y., Seibold, E., et al., Init. Repts. DSDP, 41 (Supplement to Vol. 41): Washington (U.S. Govt. Printing Office), 938-986.

1978b. Paleomagnetic results from DSDP Hole $391 \mathrm{C}$ and the magnetostratigraphy of Cretaceous sediments from the Atlantic Ocean floor. In Benson, W. E., Sheridan, R. E., et al., Init. Repts. DSDP, 44: Washington (U.S. Govt. Printing Office), 523-528.

Kent, D. V. and Gradstein, F. M., 1985. A Cretaceous and Jurassic geochronology. Geol. Soc. Am. Bull., 96:1419-1427.

Kirschvink, J. L., 1980. The least-squares line and plane and the analysis of palaeomagnetic data. Geophys. J. R. Astron. Soc., 62:699-718.

Klitgord, K. D., and Schouten, H., 1988. Plate kimematics of the Central Atlantic. In Tucholke, B. E., and Vogt, P. R. (Eds.), The Geology of North America: The Western Atlantic Region. Geol. Soc. Am. DNAG Ser., M:351-378.

Kono, M., 1980a. Paleomagnetism of DSDP Leg 55 basalts and implications for the tectonics of the Pacific plate. In Jackson, E. D., Koizumi, I., et al., Init. Repts. DSDP, 55: Washington (U.S. Govt. Printing Office), 737-752.

1980b. Statistics of paleomagnetic inclination dta. J. Geophys. Res., 85:3878-3882.

Leg 123 Shipboard Scientific Party, 1988. Sedimentology of the Argo and Gascoyne abyssal plains, NW Australia: report on Ocean Drilling Program Leg 123 (Sept.1-Nov.1, 1988). Carbonates and Evaporites, 3:201-212.

Larson, R. L., and Hilde, T.W.C., 1975. A revised time scale of magnetic reversals for the Early Cretaceous and Late Jurassic. J. Geophys. Res., $80: 2586-2594$.

Lowrie, W., and Alvarez, W., 1984. Lower Cretaceous magnetic stratigraphy in Umbrian pelagic limestone sections. Earth Planet. Sci. Lett. 71:315-328.

Lowrie, W., and Channell, J.E.T., 1984. Magnetostratigraphy of the Jurassic/Cretaceous boundary in the Maiolica limestone (Umbria, Italy). Geology, 12:44-47.

Lowrie, W., and Heller, F., 1982. Magnetic properties of marine limestones. Rev. Geophys. Space Phys., 20:171-192.
Lowrie, W., and Ogg, J. G., 1986. A magnetic polarity time scale for the Early Cretaceous and Late Jurassic. Earth Planet. Sci. Lett., 76:341349.

Ludden, J. N., Gradstein, F. M., et al., 1990. Proc. ODP, Init. Repts., 123: College Station, TX (Ocean Drilling Program).

Marton, E., 1986. The problems of correlation between magnetozones and calpionellid zones in Late Jurassic-Early Cretaceous sections. Acto Geol. Hungarica, 29:125-131.

McElhinny, M. W., 1973. Palaeomagnetism and Plate Tectonics: Cambridge (Cambridge Univ. Press).

Ogg, J. G., 1981. Sedimentology and paleomagnetic studies of Jurassic pelagic limestones: "Ammonitico Rosso" facies [Ph.D. thesis]. Univ. of California, San Diego.

1983. Magnetostratigraphy of Upper Jurassic and lowest Cretaceous sediments, Deep Sea Drilling Project Site 534, western North Atlantic. In Sheridan, R. E., Gradstein, F. M., et al., Init. Repts. DSDP. 76: Washington (U.S. Govt. Printing Office), 685-697.

1987. Early Cretaceous magnetic polarity time scale and the magnetostratigraphy of Deep Sea Drilling Project Sites 603 and 534 western Central Atlantic. In van Hinte, J. E., Wise, S. W., Jr., et al., Init. Repts. DSDP, 93: Washington (U.S. Govt. Printing Office), 849-880.

1988. Early Cretaceous and Tithonian magnetostratigraphy of the Galicia Margin (Ocean Drilling Program Leg 103). In Boillot, G. Winterer, E. L., et al., Proc. ODP, Sci. Results, 103: College Station, TX (Ocean Drilling Program), 659-682.

in press. Jurassic magnetic polarity time scale. In Westermann, G.E.G. (Ed.), Circum-Pacific Jurassic: Amsterdam (Elsevier).

Ogg, J. G., Steiner, M. B., Oloriz, F., and Tavera, J. M., 1984. Jurassic magnetostratigraphy, 1. Kimmeridgian-Tithonian of Sierra Gorda and Carcabuey, southern Spain. Earth Planet. Sci. Lett., 71:147-162.

Ogg, J. G., and Lowrie, W., 1986. Magnetostratigraphy of the Jurassic/Cretaceous boundary. Geology, 14:547-550.

Ogg, J. G., Company, M., Steiner, M. B., and Tavera, J. M., 1988. Magnetostratigraphy across the Berriasian/Valanginian stage boundary (Early Cretaceous) at Cehegin (Murcia Province), Southern Spain. Earth Planet. Sci. Lett., 87:205-215.

Ogg, J. G., and Steiner, M. B., 1988. Late Jurassic and Early Cretaceous magnetic polarity time scale. In Rocha, R. (Ed.), 2nd Int. Symp. Jurassic Stratigr. (Lisbon, Sept. 1987), 1125-1138.

Ogg, J. G., Hasenyager, R. W., Wimbledon, W. A., Channell, J.E.T., and Bralower, T. J., in press. Magnetostratigraphy of the Jurassic/Cretaceous boundary interval-Tethyan and English faunal realms. Cretaceous Res.

Ogg, J. G., and Steiner, M. B., in press. Early Triassic magnetic polarity time scale-integration of magnetostratigraphy, ammonite zonation and sequence stratigraphy from stratotype sectionzs. (Canadian Arctic Archipelago). Earth Planet. Sci. Lett.

Pechersky, D. M., and Khramov, A. N., 1973. Mesozoic paleomagnetic scale of the U.S.S.R. Nature, 244:499-501.

Powell, C. McA., Roots, S. R., and Veevers, J. J., 1988. Pre-breakup continental extension in East Gondwanaland and the early opening of the eastern Indian Ocean. Tectonophysics, 155:261-283.

Royer, J.-Y., and Sandwell, D. T., 1989. Evolution of the eastern Indian Ocean since the Late Cretaceous: constraints from Geosat altimetry. J. Geophys. Res., 94:13755-13782.

Schouten, H., and Klitgord, K. D., 1977. Map showing Mesozoic magnetic anomalies, western North Atlantic. Misc. Field Stud., U.S. Geol. Surv., Map MF-915.

1982. The memory of the accreting plate boundary and the continuity of fracture zones. Earth Planet. Sci. Lett., 59:255-266.

Shipboard Scientific Party, 1974. Site 261. In Veevers, J. J., Heirtzler, J. R., et al., Init. Repts. DSDP , 27: Washington (U.S. Govt. Printing Office), 129-192.

1986. Site 585. In Moberly, R., Schlanger, S. O., et al., Init. Repts. DSDP, 89: Washington (U.S. Govt. Printing Office), 29-155. 1990a. Site 765. In Gradstein, F. M., Ludden, J., et al., Proc. ODP, Init. Repts, 123: College Station, TX (Ocean Drilling Program), 63-267.

, 1990b. Site 766. In Gradstein, F. M., Ludden, J., et al., Proc. $O D P$, Init. Repts, 123: College Station, TX (Ocean Drilling Program), 269-352.

Steiner, M. B., 1977. Magnetization of Jurassic red deep sea sediments in the Atlantic (DSDP Site 105). Earth Planet. Sci. Lett., 35:205-214. 
Sundvik, M. T., 1985. The plate tectonic framework of the western north Atlantic Basin derived from the Keathley sequence magnetic anomaly pattern. Eos, Trans. Am. Geophys. Union, 66:368. (Abstract)

Tarduno, J. A., Sliter, W. V., Bralower, T. J., McWilliams, M., PremoliSilva, I., and Ogg, J. G., 1989. M-sequence reversals recorded in DSDP sediment cores from the western Mid-Pacific Mountains and Magellan Rise. Geol. Soc. Am. Bull., 101:1306-1316.

Vandenberg, J., and Wonders, A.A.H., 1980. Paleomagnetism of Late Mesozoic pelagic limestones from the Southern Alps. J. Geophys. Res., 85:3623-3627.

Vandenberg, J., Klootwijk, C. T., and Wonders, A.A.H., 1978. Late Mesozoic and Cenozoic movements of the Italian peninsula: further paleomagnetic data from the Umbrian sequence. Geol. Soc. Am. Bull., 89:133-150.

Veevers, J. J., Heirtzler, J. R., et al., 1974. Init. Repts. DSDP, 27: Washington (U.S. Govt. Printing Office).

Vogt, P. R., and Einwich, A. M., 1979. Magnetic anomalies and seafloor speading in the western North Atlantic, and a revised calibration of the Keathley (M) geomagnetic reversal chronology. In Tucholke, B. E., Vogt, P. R., et al., Init. Repts. DSDP, 43: Washington (U.S. Govt. Printing Office), $857-876$.

Date of initial receipt: 14 May 1990

Date of acceptance: 24 June 1991

Ms 123B-128

\section{APPENDIX}

Polarity interpretations and characteristic directions of all Late Jurassic-Early Cretaceous paleomagnetic samples from sediment cores of Sites 765,261 , and 766 . Polarity interpretation notation is normal, reversed, or indeterminate polarity (N, R, and INT, respectively), with lesser quality indicated by addition of P, PP, or ?? (half-weight, poor, or questionable reliability, respectively). Characteristic directions and mean intensities are computed from least-squares analysis of the indicated suites of selected demagnetization steps. Selected steps are thermal demagnetization levels for Holes $765 \mathrm{C}$ and 261. For Hole 766, selected steps are alternating field demagnetization levels with some additional thermal steps. "Org" indicates that the origin of the vector plot was included as a selected point for the least-squares computation due to irregular pattern of demagnetization vectors; "Tied" indicates that the least-squares vector was constrained to pass through the origin on the vector plots, thereby producing an average of the selected demagnetization steps - such "Org" and "Tied" computations are given a lower quality rating. Error column is the standard deviation angle computed on the characteristic directions that incorporate three or more vectors. 
Magnetic Polarity and Characteristic Directions

Leg 123, Site 765

\begin{tabular}{|c|c|c|c|c|c|c|c|c|c|c|c|c|c|c|}
\hline & & & Charac & ristic directio & & & & & nagnet & ation & eps use & in lea & -squar & \\
\hline interval $(\mathrm{cm})$ & (mbsf) & Polarity & Declination & Inclination & Error & $(\mathrm{A} / \mathrm{m})$ & Total & & & & Select & d level & $\left({ }^{\circ} \mathrm{C}\right)$ & \\
\hline $765 \mathrm{C}-44 \mathrm{R}-1,58$ & 759.08 & NP & 196.6 & -35.1 & 8.2 & 4.79E-04 & 3 & 450 & 550 & 600 & & & & \\
\hline $765 C-44 R-2,7$ & 760.07 & $\mathrm{~N}$ & 53.0 & -35.0 & 3.4 & $2.02 \mathrm{E}-03$ & 6 & 350 & 450 & 500 & 550 & 600 & 650 & \\
\hline $765 C-44 R-2,70$ & 760.70 & $\mathrm{~N}$ & 27.4 & -42.0 & 2.5 & $1.85 \mathrm{E}-03$ & 4 & 350 & 450 & 550 & 600 & & & \\
\hline $765 C-44 R-2,134$ & 761.34 & $\mathrm{~N}$ & 208.5 & -30.0 & 5.3 & $6.33 \mathrm{E}-04$ & 5 & 450 & 500 & 550 & 600 & 650 & & \\
\hline $765 C-44 R-3,50$ & 762.00 & NP & 52.4 & -12.1 & & $2.00 \mathrm{E}-04$ & 2 & 600 & 650 & & & & & \\
\hline $765 C-44 R-3,144$ & 762.94 & NP & 53.5 & -37.6 & 2.8 & $1.85 \mathrm{E}-03$ & 4 & 350 & 450 & 550 & 600 & & & \\
\hline $765 C-45 R-1,49$ & 768.69 & $\mathrm{~N}$ & 333.1 & -32.1 & 2.4 & $9.05 \mathrm{E}-03$ & 5 & 450 & 500 & 550 & 600 & 650 & & \\
\hline $765 \mathrm{C}-45 \mathrm{R}-1,97$ & 769.17 & $\mathrm{~N}$ & 352.9 & -50.0 & 0.5 & $4.75 \mathrm{E}-03$ & 4 & 350 & 450 & 550 & 600 & & & \\
\hline $765 \mathrm{C}-45 \mathrm{P}-1,123$ & 769.43 & $\mathrm{~N}$ & 349.7 & -41.3 & 2.0 & $1.17 \mathrm{E}-02$ & 6 & 350 & 450 & 500 & 550 & 600 & 650 & \\
\hline $765 \mathrm{C}-45 \mathrm{R}-1,145$ & 769.65 & $\mathrm{~N}$ & 341.4 & -37.7 & 2.5 & $2.91 \mathrm{E}-02$ & 8 & 300 & 350 & 400 & 450 & 500 & 550 & 600 \\
\hline $765 C-45 R-2,22$ & 769.92 & $\mathrm{~N}$ & 6.7 & -30.2 & 1.1 & $1.78 \mathrm{E}-02$ & 3 & 450 & 550 & 600 & & & & \\
\hline $765 C-45 R-2,103$ & 770.73 & NPP & 272.6 & -46.8 & 1.1 & 3.10E-03 & 5 & 450 & 500 & 550 & 600 & 650 & & \\
\hline $765 C-45 R-2,145$ & 771.15 & $\mathbf{R}$ & 130.0 & 41.5 & 4.2 & $3.12 \mathrm{E}-03$ & 4 & 450 & 500 & 550 & 600 & & & \\
\hline $765 C-45 R-3,3$ & 771.23 & RP & 287.6 & 45.5 & 7.6 & $5.22 \mathrm{E}-04$ & 5 & 450 & 500 & 550 & 600 & 650 & & \\
\hline 765C-45R-3. 98 & 772.18 & $\mathrm{~N}$ & 27.6 & -43.4 & 0.6 & $3.25 \mathrm{E}-03$ & 3 & 450 & 550 & 600 & & & & \\
\hline $765 C-45 R-4,41$ & 772.76 & NP & 43.3 & -43.1 & 3.3 & $3.61 \mathrm{E}-03$ & 6 & 350 & 450 & 500 & 550 & 600 & 650 & \\
\hline $765 C-45 R-4,107$ & 773.42 & $\mathrm{~N}$ & 30.7 & -44.8 & 0.9 & $9.29 \mathrm{E}-03$ & 4 & 350 & 450 & 550 & 600 & & & \\
\hline 765 C-4SR-5, 21 & 774.06 & $\mathrm{~N}$ & 274.2 & -41.4 & 1.1 & $5.44 \mathrm{E}-03$ & 3 & 550 & 600 & 650 & & & & \\
\hline $765 C-45 R-6,66$ & 776.01 & N?? & 192.4 & -72.1 & & $1.66 \mathrm{E}-02$ & 2 & 550 & 600 & & & & & \\
\hline $765 C-46 R-2,18$ & 779.48 & $\mathrm{~N}$ & 24.8 & -34.3 & 2.6 & $5.21 \mathrm{E}-03$ & 4 & 500 & 550 & 600 & 650 & & & \\
\hline $765 \mathrm{C}-46 \mathrm{R}-2,89$ & 780.19 & $\mathrm{~N}$ & 60.1 & -35.7 & 1.6 & $1.47 \mathrm{E}-02$ & 3 & 450 & 550 & 600 & & & & \\
\hline $765 C-47 R-1,141$ & 788.81 & RP & 49.1 & 26.5 & & $2.18 \mathrm{E}-04$ & 2 & 600 & 650 & & & & & \\
\hline $765 C-47 R-2,81$ & 789.71 & RPP & 151.6 & 30.5 & & $1.05 \mathrm{E}-02$ & 2 & 500 & 600 & & & & & \\
\hline $765 \mathrm{C}-47 \mathrm{R}-3,68$ & 791.08 & $\mathbf{R}$ & 177.9 & 42.9 & 2.0 & $1.84 \mathrm{E}-03$ & 3 & 550 & 600 & 650 & & & & \\
\hline $765 C-47 R-3,95$ & 791.35 & RPP & 203.5 & 22.6 & 2.9 & $2.43 \mathrm{E}-03$ & 3 & 500 & 550 & 600 & & & & \\
\hline $765 C-47 R-4,28$ & 792.18 & RPP & 1.2 & 32.9 & & $1.83 \mathrm{E}-04$ & 2 & 550 & 600 & & & & & \\
\hline $765 C-47 R-4,133$ & 793.23 & RP & 231.2 & 39.3 & & $1.26 \mathrm{E}-02$ & 2 & 550 & 600 & & & & & \\
\hline $765 C-47 R-5,9$ & 793.49 & $\mathrm{~N}$ & 59.5 & -46.5 & 3.7 & $2.03 \mathrm{E}-02$ & 5 & 450 & 500 & 550 & 600 & 650 & & \\
\hline $765 C-48 R-1,68$ & 797.58 & $N$ & 17.6 & -54.2 & 3.2 & $1.94 \mathrm{E}-03$ & 3 & 450 & 550 & 600 & & & & \\
\hline $765 C-48 R-2,81$ & 799.21 & $\mathrm{~N}$ & 14.7 & -42.0 & 3.5 & $3.16 \mathrm{E}-03$ & 4 & 450 & 500 & 550 & 600 & & & \\
\hline $765 C-48 R-3,64$ & 800.54 & $\mathrm{~N}$ & 331.3 & -40.7 & 1.3 & $1.54 \mathrm{E}-02$ & 3 & 450 & 550 & 600 & & & & \\
\hline $765 \mathrm{C}-48 \mathrm{R}-4,27$ & 801.32 & $\mathrm{~N}$ & 210.7 & -43.7 & 3.5 & $3.59 \mathrm{E}-04$ & 4 & 500 & 550 & 600 & 650 & & & \\
\hline $765 C-48 R-5,5$ & 802.60 & $\mathrm{~N}$ & 87.0 & -48.9 & 2.1 & $2.70 \mathrm{E}-03$ & 6 & 356 & 450 & 500 & 550 & 600 & 650 & \\
\hline $765 C-48 R-5,51$ & 803.06 & $\mathrm{~N}$ & 39.6 & -44.0 & 1.5 & $3.98 \mathrm{E}-03$ & 5 & 350 & 450 & 500 & 550 & 600 & & \\
\hline $765 C-48 R-6,86$ & 803.41 & $\mathrm{~N}$ & 27.2 & -38.0 & 3.6 & $8.24 \mathrm{E}-04$ & 5 & 450 & 500 & 550 & 600 & 650 & & \\
\hline $765 C-49 R-1,75$ & 807.05 & $\mathrm{~N}$ & 325.8 & -10.9 & 1.9 & $1.09 \mathrm{E}-03$ & 4 & 350 & 450 & 550 & 600 & & & \\
\hline $765 \mathrm{C}-49 \mathrm{R}-2,19$ & 807.99 & NP & 350.7 & -43.7 & & $5.48 \mathrm{E}-04$ & 2 & 500 & 550 & & & & & \\
\hline $765 \mathrm{C}-49 \mathrm{R}-3,90$ & 810.20 & $\mathrm{~N}$ & 25.5 & -35.8 & 4.7 & $1.88 \mathrm{E}-02$ & 4 & 450 & 500 & 550 & 600 & & & \\
\hline $765 C-49 R-4,89$ & 811.69 & $\mathrm{~N}$ & 41.9 & -39.9 & 2.7 & $2.38 \mathrm{E}-02$ & 5 & 450 & 500 & 550 & 600 & 650 & & \\
\hline $765 C-49 R-5,61$ & 812.91 & $N$ & 57.1 & -41.6 & 1.1 & $1.07 \mathrm{E}-02$ & 3 & 450 & 550 & 600 & & & & \\
\hline 765 C-50R-1, 74 & 816.34 & $\mathrm{~N}$ & 17.8 & -35.7 & 1.7 & $2.12 \mathrm{E}-02$ & 6 & 350 & 450 & 500 & 550 & 600 & 650 & \\
\hline $765 C-50 R-2,37$ & 817.47 & NP & 46.2 & -37.5 & 1.2 & $1.83 \mathrm{E}-02$ & 4 & 350 & 450 & 550 & 600 & & & \\
\hline $765 \mathrm{C}-50 \mathrm{R}-3,82$ & 819.42 & $\mathrm{~N}$ & 24.6 & -37.6 & 2.2 & $2.24 \mathrm{E}-03$ & 6 & 350 & 450 & 500 & 550 & 600 & 650 & \\
\hline $765 C-50 R-4,86$ & 820.96 & $\mathrm{~N}$ & 36.8 & -39.2 & 4.2 & $3.38 \mathrm{E}-02$ & 4 & 450 & 500 & 550 & 600 & & & \\
\hline $765 C-50 R-5,81$ & 822.41 & $N$ & 26.9 & -34.8 & 1.5 & $2.75 \mathrm{E}-02$ & 6 & 350 & 450 & 500 & 550 & 600 & 650 & \\
\hline $765 \mathrm{C}-50 \mathrm{R}-6,43$ & 82.3 .53 & $\mathrm{~N}$ & 12.0 & -47.3 & 0.8 & $1.32 \mathrm{E}-02$ & 5 & 350 & 450 & 500 & 550 & 600 & & \\
\hline $765 C-51 R-1,71$ & 825.71 & $\mathrm{~N}$ & 4.5 & -35.8 & 3.3 & $1.21 \mathrm{E}-02$ & 6 & 350 & 450 & 500 & 550 & 600 & 650 & \\
\hline $765 C-51 R-2,76$ & 827.26 & $\mathrm{~N}$ & 53.1 & -27.4 & 1.0 & $2.99 \mathrm{E}-02$ & 4 & 450 & 500 & 550 & 600 & & & \\
\hline $765 C-51 R-3,53$ & 828.53 & $\mathrm{~N}$ & 5.2 & -32.4 & 1.1 & $7.38 \mathrm{E}-03$ & 6 & 350 & 450 & 500 & 550 & 600 & 650 & \\
\hline $765 C-51 R-4,32$ & 829.82 & $\mathrm{~N}$ & 55.0 & -40.8 & 0.7 & $3.97 \mathrm{E}-02$ & 5 & 350 & 450 & 500 & 550 & 600 & & \\
\hline $765 C-51 R-4,123$ & 830.73 & $\mathrm{~N}$ & 226.1 & -40.5 & 2.3 & 4.19E-02 & 6 & 350 & 450 & 500 & 550 & 600 & 650 & \\
\hline $765 C-51 R-5,37$ & 831.37 & $\mathrm{~N}$ & 36.5 & -48.3 & 2.5 & $6.13 \mathrm{E}-03$ & 4 & 450 & 500 & 550 & 600 & & & \\
\hline $765 C-51 \mathrm{R}-6,114$ & 832.14 & $\mathrm{~N}$ & 190.0 & -39.6 & 2.8 & $7.70 \mathrm{E}-03$ & 6 & 350 & 450 & 500 & 550 & 600 & 650 & \\
\hline $765 C-51 R-9,12$ & 833.62 & $\mathbf{R}$ & 231.1 & 28.7 & 2.5 & 2.85E-03 & 4 & 450 & 500 & 550 & 600 & & & \\
\hline $765 C-52 R-1,67$ & 835.17 & $\mathbf{R}$ & 202.2 & 16.0 & 1.3 & $4.96 \mathrm{E}-03$ & 5 & 350 & 450 & 500 & 550 & 650 & & \\
\hline $765 \mathrm{C}-52 \mathrm{R}-1,125$ & 835.75 & $R$ & 224.8 & 27.0 & 1.6 & $4.75 \mathrm{E}-03$ & 4 & 450 & 500 & 550 & 600 & & & \\
\hline $765 C-52 R-2,43$ & 836.43 & $\mathrm{R}$ & 252.1 & 50.1 & 2.6 & $5.46 \mathrm{E}-03$ & 6 & 350 & 450 & 500 & 550 & 600 & 650 & \\
\hline $765 C-52 R-2,86$ & 836.86 & RPP & 331.7 & 39.9 & 1.1 & $6.54 \mathrm{E}-03$ & 4 & 450 & 500 & 550 & 600 & & & \\
\hline $765 C-52 R-2,103$ & 837.03 & $\mathrm{R}$ & 187.6 & 32.4 & 3.9 & $3.16 \mathrm{E}-03$ & 6 & 350 & 450 & 500 & 550 & 600 & 650 & \\
\hline $765 C-52 R-3,5$ & 837.55 & RPP & 187.8 & 33.6 & 0.6 & $1.44 \mathrm{E}-02$ & 4 & 450 & 500 & 550 & 600 & & & \\
\hline $765 C-52 R-3,38$ & 837.88 & $\mathbf{R}$ & 186.0 & 43.7 & 4.7 & $1.43 \mathrm{E}-02$ & 3 & 500 & 550 & 600 & & & & \\
\hline $765 C-52 R-3,44$ & 837.94 & $\mathbf{R}$ & 198.1 & 33.6 & 3.1 & $1.31 \mathrm{E}-02$ & 4 & 500 & 550 & 600 & 650 & & & \\
\hline $765 C-52 R-3,80$ & 838.30 & $\mathbf{R}$ & 207.5 & 24.2 & 3.1 & $1.79 \mathrm{E}-02$ & 4 & 450 & 500 & 550 & 600 & & & \\
\hline $765 C-52 R-3,113$ & 838.63 & $\mathbf{R}$ & 197.2 & 23.8 & 4.1 & $1.46 \mathrm{E}-02$ & 5 & 450 & 500 & 550 & 600 & 650 & & \\
\hline $765 C-53 R-1,13$ & 844.23 & $\mathbf{R}$ & 152.3 & 33.3 & 1.6 & $1.59 \mathrm{E}-02$ & 5 & 350 & 450 & 500 & 550 & 600 & & \\
\hline $765 C-53 R-1,46$ & 844.56 & $\mathbf{R}$ & 122.7 & 32.4 & 4.1 & $3.88 \mathrm{E}-03$ & 4 & 450 & 500 & 550 & 600 & & & \\
\hline $765 C-53 R-1,83$ & 844.93 & $\mathrm{~N}$ & 43.9 & -38.5 & 1.2 & $1.14 \mathrm{E}-02$ & 5 & 350 & 450 & 500 & 550 & 600 & & \\
\hline $765 C-53 R-1,134$ & 845.44 & NP & 39.6 & -45.0 & 4.1 & $2.97 \mathrm{E}-03$ & 5 & 450 & 500 & 550 & 600 & 650 & & \\
\hline $765 C-53 R-2,19$ & 845.79 & $\mathrm{~N}$ & 26.8 & -42.6 & 1.9 & $3.62 \mathrm{E}-03$ & 5 & 350 & 450 & 500 & 550 & 600 & & \\
\hline $765 C-53 R-2,43$ & 846.03 & $\mathrm{~N}$ & 347.3 & -41.1 & 2.5 & 3.83E-03 & 6 & 350 & 450 & 500 & 550 & 600 & 650 & \\
\hline $765 C-53 R-2,66$ & 846.26 & $\mathrm{~N}$ & 27.0 & -43.0 & 1.4 & $3.86 \mathrm{E}-03$ & 5 & 350 & 450 & 500 & 550 & 600 & & \\
\hline $765 C-53 R-2,94$ & 846.54 & RP & 169.0 & 16.3 & 9.8 & $6.62 \mathrm{E}-04$ & 3 & 550 & 600 & 650 & & & & \\
\hline $765 C-53 R-2,134$ & 846.94 & $R$ & 160.0 & 28.3 & 3.4 & $5.79 \mathrm{E}-03$ & 4 & 450 & 500 & 550 & 600 & & & \\
\hline $765 C-53 R-3,17$ & 847.27 & RP & 195.4 & 22.7 & & $1.22 \mathrm{E}-03$ & 2 & 600 & 650 & & & & & \\
\hline $765 C-53 R-3,44$ & 847.54 & $\mathrm{R}$ & 200.2 & 45.8 & 4.4 & $3.07 \mathrm{E}-03$ & 4 & 450 & 500 & 550 & 600 & & & \\
\hline $765 C-53 R-3,73$ & 847.83 & RP & 203.6 & 32.6 & 7.3 & $4.75 \mathrm{E}-03$ & 3 & 550 & 600 & 650 & & & & \\
\hline $765 C-53 R-3,98$ & 848.08 & $\mathbf{R}$ & 209.4 & 35.9 & 3.5 & $5.38 \mathrm{E}-03$ & 4 & 450 & 500 & 550 & 600 & & & \\
\hline $765 C-53 R-3,137$ & 848.47 & $\mathbf{R}$ & 205.6 & 25.8 & 3.9 & $6.45 \mathrm{E}-03$ & 3 & 550 & 600 & 650 & & & & \\
\hline $765 C-53 R-4,16$ & 848.76 & RP & 203.6 & 23.8 & & $4.54 \mathrm{E}-03$ & 2 & 550 & 600 & & & & & \\
\hline $765 C-53 R-4,51$ & 849.11 & R?? & 203.1 & -36.5 & & 1.39E-04 & 2 & 600 & 650 & & & & & \\
\hline $765 C-53 R-4,73$ & 849.33 & RP & 190.6 & 33.8 & & $4.64 \mathrm{E}-03$ & 2 & 550 & 600 & & & & & \\
\hline $765 C-53 R-4,103$ & 849.63 & $\mathbf{R}$ & 188.6 & 35.2 & 4.6 & 4.63E- 03 & 5 & 450 & 500 & 550 & 600 & 650 & & \\
\hline
\end{tabular}




\begin{tabular}{|c|c|c|c|c|c|c|c|c|c|c|c|c|}
\hline ection, & Met & & Charac & eristic directio & & & & & nagnet & ation s & eps use & in leas \\
\hline interval $(\mathrm{cm})$ & (mbsf) & Polarity & Declination & Inclination & Error & $(\mathrm{A} / \mathrm{m})$ & Total & & & & Select & d levels \\
\hline $765 C-53 R-4,143$ & 850.03 & $\mathbf{R}$ & 131.7 & 35.5 & 0.6 & $6.93 \mathrm{E}-03$ & 3 & 500 & 550 & 600 & & \\
\hline $765 C-53 R-5,11$ & 850.21 & RPP & 58.4 & 0.3 & & $2.81 \mathrm{E}-03$ & 2 & 600 & 650 & & & \\
\hline $765 C-53 R-5,44$ & 850.54 & RPP & 121.1 & 15.3 & & $5.65 \mathrm{E}-04$ & 1 & 600 & & & & \\
\hline $765 \mathrm{C}-53 \mathrm{R}-5,96$ & 851.06 & $\mathrm{R}$ & 197.9 & 38.3 & 4.4 & $5.30 \mathrm{E}-03$ & 5 & 450 & 500 & 550 & 600 & 650 \\
\hline $765 C-53 R-6,20$ & 851.80 & $\mathbf{R}$ & 154.2 & 19.3 & 4.1 & $5.53 \mathrm{E}-03$ & 4 & 450 & 500 & 550 & 600 & \\
\hline $765 \mathrm{C}-53 \mathrm{R}-6,28$ & 851.88 & RPP & 261.1 & 33.0 & 4.9 & 3.57E-03 & 5 & 450 & 500 & 550 & 600 & 650 \\
\hline $765 C-53 R \cdot 6,71$ & 852.31 & RP & 164.7 & 26.1 & & $5.14 \mathrm{E}-03$ & 2 & 550 & 600 & & & \\
\hline 765C-53R-6, 109 & 852.69 & $\mathbf{R}$ & 160.4 & 31.0 & 1.3 & $3.56 \mathrm{E}-03$ & 3 & 550 & 600 & 650 & & \\
\hline $765 C-53 R-6,139$ & 852.99 & $\mathbf{R}$ & 157.6 & 32.7 & 4.2 & 1. $89 \mathrm{E}-02$ & 5 & 450 & 500 & 550 & 600 & 650 \\
\hline $765 C-53 R-7,13$ & 853.00 & $\mathbf{R}$ & 152.1 & 31.2 & 1.8 & $8.54 \mathrm{E}-03$ & 3 & 500 & 550 & 600 & & \\
\hline $765 C-53 R-7,35$ & 853.10 & $\mathrm{RP}$ & 154.9 & 43.6 & 5.1 & $8.44 \mathrm{E}-03$ & 4 & 500 & 550 & 600 & 650 & \\
\hline $765 \mathrm{C}-53 \mathrm{R}-7,65$ & 853.20 & RP & 158.2 & 31.3 & & $6.99 \mathrm{E}-03$ & 2 & 550 & 600 & & & \\
\hline $765 C-53 R-9,8$ & 853.30 & RPP & 343.5 & -42.9 & & $5.30 \mathrm{E}-03$ & 2 & 600 & 650 & & & \\
\hline $765 \mathrm{C}-53 \mathrm{R}-9,32$ & 853.40 & $\mathbf{R}$ & 122.1 & 30.1 & 2.6 & $8.73 \mathrm{E}-03$ & 3 & 500 & 550 & 600 & & \\
\hline $765 \mathrm{C}-54 \mathrm{R}-1,17$ & 853.67 & RP & 198.8 & 34.8 & 4.5 & $2.26 \mathrm{E}-03$ & 3 & 550 & 600 & 650 & & \\
\hline $765 \mathrm{C}-54 \mathrm{R}-1,35$ & 853.85 & $\mathrm{RP}$ & 223.3 & 20.5 & & $4.62 \mathrm{E}-04$ & 2 & 500 & 550 & & & \\
\hline $765 C-54 R-1,85$ & 854.35 & $\mathbf{R}$ & 222.8 & 35.0 & 4.5 & $2.50 \mathrm{E}-03$ & 4 & 500 & 550 & 600 & 650 & \\
\hline $765 \mathrm{C}-54 \mathrm{R}-1,117$ & 854.67 & RPP & 241.4 & 8.3 & & $8.02 \mathrm{E}-04$ & 2 & 550 & 600 & & & \\
\hline $765 C-54 R-1,143$ & 854.93 & $\mathrm{R}$ & 229.2 & 37.4 & 4.3 & $1.16 \mathrm{E}-03$ & 3 & 550 & 600 & 650 & & \\
\hline $765 \mathrm{C}-54 \mathrm{R}-2,32$ & 855.32 & $\ddot{R}$ & 213.7 & 28.7 & 4.0 & $2.59 \mathrm{E}-03$ & 5 & 350 & 450 & 500 & 550 & 600 \\
\hline $765 C-54 R-2,58$ & 855.58 & $\mathrm{R}$ & 211.7 & 44.3 & 3.5 & $1.78 \mathrm{E}-03$ & 5 & 450 & 500 & 550 & 600 & 650 \\
\hline $765 \mathrm{C}-54 \mathrm{R}-2,87$ & 855.87 & RP & 145.4 & 27.8 & 6.0 & $3.04 \mathrm{E}-03$ & 3 & 450 & 550 & 600 & & \\
\hline $765 \mathrm{C}-54 \mathrm{R}-2,122$ & 856.22 & $\mathrm{RP}$ & 194.5 & 30.9 & 5.3 & $3.27 \mathrm{E}-03$ & 5 & 450 & 500 & 550 & 600 & 650 \\
\hline 765C-54R-3, 4 & 856.54 & RPP & 139.6 & 12.9 & & $4.38 \mathrm{E}-04$ & 1 & 600 & Org & & & \\
\hline $765 \mathrm{C}-54 \mathrm{R}-3,34$ & 856.84 & NP & 18.1 & -32.8 & & $8.15 \mathrm{E}-04$ & 2 & 600 & $650^{\circ}$ & & & \\
\hline $765 \mathrm{C}-54 \mathrm{R}-3,75$ & 857.25 & $\mathrm{~N}$ & 25.9 & -36.7 & 1.1 & 1. $10 \mathrm{E}-02$ & 5 & 350 & 450 & 500 & 550 & 600 \\
\hline $765 C-54 R-3,112$ & 857.62 & NP & 312.7 & -32.7 & & $7.95 \mathrm{E}-04$ & 2 & 600 & 650 & & & \\
\hline $765 \mathrm{C}-54 \mathrm{R}-4,32$ & 858.32 & $\mathrm{~N}$ & 348.3 & -49.6 & 1.3 & $6.51 \mathrm{E}-04$ & 3 & 550 & 600 & 650 & & \\
\hline $765 \mathrm{C}-54 \mathrm{R}-4,81$ & 858.81 & INT & 72.2 & 5.4 & & $7.05 E-05$ & 1 & 600 & & & & \\
\hline $765 \mathrm{C}-55 \mathrm{R}-1,29$ & 863.29 & $\mathrm{~N}$ & 31.2 & -40.2 & 3.2 & $3.52 \mathrm{E}-03$ & 5 & 350 & 450 & 500 & 550 & 600 \\
\hline $765 \mathrm{C}-55 \mathrm{R}-1,64$ & 863.64 & NP & 37.3 & -42.7 & 5.4 & $1.45 \mathrm{E}-03$ & 4 & 450 & 500 & 550 & 600 & \\
\hline $765 \mathrm{C}-55 \mathrm{R}-1,98$ & 863.98 & $\mathrm{R}$ ?? & 190.8 & 25.4 & & $1.56 \mathrm{E}-04$ & $i$ & 650 & & & & \\
\hline $765 \mathrm{C}-55 \mathrm{R}-1,133$ & 864.33 & $\mathrm{R}$ ?? & 228.1 & -68.6 & & $1.81 \mathrm{E}-04$ & 1 & 600 & & & & \\
\hline $765 \mathrm{C}-55 \mathrm{R}-2,17$ & 864.67 & RPP & 147.7 & -2.4 & & 7.15E-05 & $i$ & 550 & & & & \\
\hline $765 \mathrm{C}-55 \mathrm{R}-2,49$ & 864.99 & $\mathrm{R}$ & 219.6 & 27.2 & 3.8 & $2.14 \mathrm{E}-03$ & 4 & 450 & 500 & 550 & 600 & \\
\hline $765 C-55 R-2,101$ & 865.51 & RP & 206.8 & 40.5 & & $6.69 \mathrm{E}-04$ & 2 & 600 & 650 & & & \\
\hline $765 C-55 R-2,138$ & 865.88 & RPP & 37.0 & 24.5 & 1.9 & $1.98 \mathrm{E}-03$ & 3 & 500 & 550 & 600 & & \\
\hline $765 C-55 R-3,6$ & 866.06 & R & 202.0 & 35.9 & 3.8 & $1.53 \mathrm{E}-03$ & 5 & 450 & 500 & 550 & 600 & 650 \\
\hline $765 \mathrm{C}-55 \mathrm{R}-3,+8$ & 866.48 & RPP & 198.0 & 21.7 & & $5.45 \mathrm{E}-04$ & 1 & 600 & & & & \\
\hline $765 C-55 R-3,86$ & 866.86 & INT & 113.4 & -29.8 & & $8.55 \mathrm{E}-05$ & 1 & 550 & & & & \\
\hline $765 C-55 \mathrm{R}-3,131$ & 867.31 & $\mathrm{R}$ ?? & 211.3 & -21.1 & & $1.68 \mathrm{E}-04$ & $i$ & 600 & & & & \\
\hline $765 C-55 R-4,39 A$ & 867.89 & $\mathrm{R}$ & 142.1 & 44.9 & 2.1 & $1.41 \mathrm{E}-03$ & 4 & 500 & 550 & 600 & 650 & \\
\hline $765 C-55 R-4,39 B$ & 867.89 & $\mathrm{~N}$ & 341.3 & -41.7 & 3.3 & $2.46 \mathrm{E}-03$ & 7 & 350 & 400 & 450 & 500 & 550 \\
\hline $765 C-55 R-4,53$ & 868.03 & N?? & 11.1 & -47.8 & & i. $19 \mathrm{E}-03$ & $i$ & 600 & & & & \\
\hline $765 \mathrm{C}-56 \mathrm{R}-1,21$ & 872.71 & $\mathrm{~N}$ & 351.4 & -51.4 & 2.0 & $2.08 \mathrm{E}-03$ & 4 & 350 & 450 & 500 & 550 & \\
\hline $765 C-56 R-1,53$ & 873.03 & $\mathrm{~N}$ & 351.6 & -37.3 & 3.9 & $5.01 \mathrm{E}-03$ & 5 & 350 & 450 & 500 & 550 & 600 \\
\hline $765 \mathrm{C}-56 \mathrm{R}-1,92$ & 873.42 & RPP & 195.2 & 21.2 & & $2.46 \mathrm{E}-04$ & 1 & 600 & & & & \\
\hline $765 C-56 R-1,129$ & 873.79 & $\mathbf{R}$ & 190.3 & 27.4 & 5.6 & $1.89 \mathrm{E}-03$ & 4 & 500 & 550 & 600 & 650 & \\
\hline $765 \mathrm{C}-56 \mathrm{R}-2,31$ & 874.31 & RP & 227.7 & 32.1 & & $1.94 \mathrm{E}-03$ & 2 & 550 & 600 & & & \\
\hline $765 \mathrm{C}-56 \mathrm{R}-2,53$ & 874.53 & RP & 207,8 & 24.1 & & $1.60 \mathrm{E}-03$ & 2 & 600 & 650 & & & \\
\hline $765 \mathrm{C}-56 \mathrm{R}-2,85$ & 874.85 & RPP & 189.4 & 34.7 & & $3.20 \mathrm{E}-04$ & i & 600 & & & & \\
\hline $765 \mathrm{C}-56 \mathrm{R}-2,134$ & 875.34 & $R P$ & 212.5 & 26.4 & & $5.97 \mathrm{E}-04$ & 2 & 550 & 600 & & & \\
\hline $765 C-56 R-3,6$ & 875.56 & INT & 8.2 & -12.8 & & 4.05E-04 & 1 & 600 & & & & \\
\hline $765 \mathrm{C}-56 \mathrm{R}-3,23$ & 875.73 & NPP & 32.5 & -25.3 & & $2.46 \mathrm{E}-04$ & 2 & 550 & 600 & & & \\
\hline $765 C-56 R-3,101$ & 876.51 & NPP & 254.3 & -24.6 & 3.5 & 3. $32 \mathrm{E}-03$ & 5 & 350 & 450 & 500 & 550 & 600 \\
\hline $765 C-56 \mathrm{R}-4,10$ & 877.10 & NPP & 312.0 & -64.5 & 15.8 & $2.13 \mathrm{E}-04$ & 3 & 500 & 550 & 600 & & \\
\hline $765 \mathrm{C}-56 \mathrm{R}-4,75$ & 877.75 & INT & 177.3 & -2.6 & & $9.51 \mathrm{E}-05$ & 1 & 600 & & & & \\
\hline $765 \mathrm{C}-57 \mathrm{R}-1,33$ & 882.03 & RPP & 310.3 & 25.1 & & $3.04 \mathrm{E}-04$ & $i$ & 650 & & & & \\
\hline $765 \mathrm{C}-57 \mathrm{R}-1,84$ & 882.54 & RP & 214.8 & 24.6 & & $3.94 \mathrm{E}-03$ & 2 & 550 & 600 & & & \\
\hline $765 \mathrm{C}-57 \mathrm{R}-1,130$ & 883.00 & $\mathrm{R}$ & 146.4 & 29.4 & 4.5 & $1.43 \mathrm{E}-03$ & 3 & 550 & 600 & 650 & & \\
\hline $765 \mathrm{C}-57 \mathrm{R}-2,88$ & 884.08 & $\mathrm{~N}$ & 33.1 & -43.6 & 4.1 & $4.92 \mathrm{E}-03$ & 4 & 450 & 500 & 550 & 600 & \\
\hline $765 C-57 R-2,134$ & 884.54 & $\mathrm{~N}$ & 2.7 & -37.9 & 4.3 & $5.28 \mathrm{E}-03$ & 4 & 450 & 500 & 550 & 600 & \\
\hline $765 C-57 R-3,43$ & 885.13 & NP & 25.5 & -45.6 & 6.3 & 3.16E-03 & 3 & 450 & 500 & 550 & & \\
\hline $765 \mathrm{C}-57 \mathrm{R}-4,85$ & 887.05 & $\mathrm{~N}$ & 0.5 & -31.9 & 3.3 & $1.58 \mathrm{E}-03$ & 4 & 500 & 550 & 600 & 650 & \\
\hline $765 \mathrm{C}-57 \mathrm{R}-4,138$ & 887.58 & RPP & 140.1 & 31.8 & & $5.02 \mathrm{E}-04$ & 2 & 550 & 600 & & & \\
\hline $765 C-57 R-5,20$ & 887.90 & $\mathrm{R}$ & 190.2 & 40.1 & 3.8 & $2.14 \mathrm{E}-03$ & 5 & 450 & 500 & 550 & 600 & 650 \\
\hline $765 C-57 R-5,81$ & 888.51 & RP & 159.1 & 46.1 & 8.3 & $5.54 \mathrm{E}-03$ & 4 & 450 & 500 & 550 & 600 & \\
\hline $765 C-57 R-5,127$ & 888.97 & RP & 160.7 & 31.7 & 5.9 & $7.15 \mathrm{E}-03$ & 4 & 500 & 550 & 600 & 650 & \\
\hline $765 C-57 R-6,29$ & 889.49 & $\mathrm{R}$ & 164.8 & 24.2 & 3.7 & 3.78E-03 & 3 & 500 & 550 & 600 & & \\
\hline $765 \mathrm{C}-57 \mathrm{R}-6,81$ & 890.01 & $\widehat{N}$ & 29.3 & -44.3 & 1.3 & $1.47 \mathrm{E}-02$ & 6 & 350 & 450 & 500 & 550 & 600 \\
\hline $765 C-57 R-7,16$ & 890.86 & NPP & 79.4 & -49.3 & 0.7 & $2.39 \mathrm{E}-02$ & 5 & 350 & 450 & 500 & 550 & 600 \\
\hline $765 \mathrm{C}-58 \mathrm{R}-1,37$ & 891.57 & $\mathrm{R}$ ?? & 129.0 & -30.5 & & $8.49 \mathrm{E}-05$ & i & 650 & & & & \\
\hline $765 \mathrm{C}-58 \mathrm{R}-1,70$ & 891.90 & $\mathrm{R}$ ?? & 197.9 & -69.3 & & $2.95 \mathrm{E}-04$ & i & 600 & & & & \\
\hline $765 \mathrm{C}-58 \mathrm{R}-1,119$ & 892.39 & $\mathrm{R}$ ?? & 243.1 & 12.4 & & $1.20 \mathrm{E}-04$ & i & 650 & & & & \\
\hline $765 \mathrm{C}-58 \mathrm{R}-2,52$ & 893.22 & R?? & 159.3 & -33.2 & 4.8 & $1.67 \mathrm{E}-03$ & 5 & 350 & 450 & 500 & 550 & 600 \\
\hline $765 \mathrm{C}-58 \mathrm{R}-2,71$ & 893.41 & $\mathrm{R}$ ?? & 145.6 & 21.3 & & $2.74 \mathrm{E}-04$ & $i$ & 650 & & & & \\
\hline $765 C-58 R-2,101$ & 893.71 & $\mathrm{R}$ ?? & 194.9 & -34.5 & 2.2 & $2.35 \mathrm{E}-03$ & 4 & 450 & 500 & 550 & 600 & \\
\hline $765 C-58 R-2,146$ & 894.16 & RP & 224.5 & 28.0 & & $1.61 \mathrm{E}-03$ & 2 & 600 & 650 & & & \\
\hline $765 \mathrm{C}-58 \mathrm{R}-3,22$ & 894.42 & $\mathrm{~N}$ & 26.3 & -44.5 & 3.5 & $6.24 \mathrm{E}-03$ & 4 & 450 & 500 & 550 & 600 & \\
\hline $765 \mathrm{C}-58 \mathrm{R}-3,6 \mathrm{I}$ & 894.81 & $\mathrm{~N}$ & 36.2 & -44.9 & 2.3 & $4.44 \mathrm{E}-03$ & 6 & 350 & 450 & 500 & 550 & 600 \\
\hline $765 \mathrm{C}-58 \mathrm{R}-3,94$ & 895.14 & $\mathrm{~N}$ & 25.8 & -39.0 & 3.8 & $1.30 \mathrm{E}-02$ & 4 & 450 & 500 & 550 & 600 & \\
\hline $765 C-58 R-3,121$ & 895.41 & $\mathrm{R}$ & 205.9 & 42.5 & 2.3 & 3.54E-04 & 3 & 550 & 600 & 650 & & \\
\hline $765 \mathrm{C}-58 \mathrm{R}-4,18$ & 895.88 & $\mathrm{~N}$ & 41.5 & -44.3 & 4.1 & $1.04 \mathrm{E}-02$ & 4 & 450 & 500 & 550 & 600 & \\
\hline $765 \mathrm{C}-58 \mathrm{R}-4,56$ & 896.26 & $\mathrm{~N}$ & 50.1 & -45.4 & 2.0 & $6.28 \mathrm{E}-03$ & 5 & 450 & 500 & 550 & 600 & 650 \\
\hline
\end{tabular}




\begin{tabular}{|c|c|c|c|c|c|c|c|c|c|c|c|c|c|}
\hline \multirow{2}{*}{$\begin{array}{l}\text { Core, section, } \\
\text { interval }(\mathrm{cm})\end{array}$} & \multirow{2}{*}{$\begin{array}{l}\text { Meter level } \\
\text { (mbsf) }\end{array}$} & & Charac & eristic directic & & Mean intensity & & & nagnet & ation & eps use & in lea & t-squares \\
\hline & & Polarity & Declination & Inclination & Error & $(A / m)$ & Total & & & & Select & d level & $\left({ }^{\circ} \mathrm{C}\right)$ \\
\hline $765 C-58 R-4,97$ & 896.67 & $\mathrm{~N}$ & 21.6 & -43.6 & 2.0 & $1.25 \mathrm{E}-02$ & 5 & 350 & 450 & 500 & 550 & 600 & \\
\hline $765 C-58 R-4,136$ & 897.06 & $\mathrm{~N}$ & 24.7 & -44.8 & 2.2 & $5.79 \mathrm{E}-03$ & 6 & 350 & 450 & 500 & 550 & 600 & 650 \\
\hline $765 C-58 R-5,8$ & 897.28 & $\mathrm{~N}$ & 0.4 & -40.5 & 3.2 & $1.44 \mathrm{E}-02$ & 5 & 350 & 450 & 500 & 550 & 600 & \\
\hline $765 C-58 R-5,75$ & 897.40 & RP & 338.4 & 23.3 & 2.0 & $1.13 \mathrm{E}-03$ & 3 & 550 & 600 & 650 & & & \\
\hline $765 C-58 R-5,138$ & 897.60 & $R$ & 239.7 & 28.9 & 4.6 & $4.96 \mathrm{E}-03$ & 4 & 450 & 500 & 550 & 600 & & \\
\hline $765 C-59 R-1,40$ & 898.30 & NP & 357.0 & -45.4 & 6.7 & $1.75 \mathrm{E}-03$ & 5 & 450 & 500 & 550 & 600 & 650 & \\
\hline $765 C-59 R-1,73$ & 898.63 & $\mathrm{~N}$ & 1.7 & -47.9 & 2.0 & 3.01 E- 03 & 4 & 450 & 500 & 550 & 600 & & \\
\hline $765 C-59 R-1,104$ & 898.94 & $\mathrm{~N}$ & 16.6 & -36.2 & 3.4 & $1.51 \mathrm{E}-02$ & 5 & 450 & 500 & 550 & 600 & 650 & \\
\hline $765 C \cdot 59 R-2,36$ & 899.76 & $\mathrm{~N}$ & 359.7 & -48.7 & 2.9 & $2.20 \mathrm{E}-03$ & 4 & 450 & 500 & 550 & 600 & & \\
\hline 765C-59R-2, 63 & 900.03 & R?? & 167.9 & 1.9 & & $2.68 \mathrm{E}-04$ & 1 & 650 & & & & & \\
\hline $765 C-59 \mathrm{R}-2,105$ & 900.45 & RPP & 220.4 & 22.3 & & $1.01 \mathrm{E}-03$ & 1 & 600 & & & & & \\
\hline 765C-59R-3, 24 & 901.14 & RPP & 170.2 & 37.0 & & $1.48 \mathrm{E}-03$ & 1 & 650 & & & & & \\
\hline 765C-59R-3, 51 & 901.41 & INT & 255.2 & 15.2 & & 2.32E-04 & 1 & 600 & & & & & \\
\hline 765C-59R-3, 69 & 901.59 & $\mathrm{~N}$ & 173.4 & -41.7 & 2.5 & $2.22 \mathrm{E}-03$ & 5 & 350 & 450 & 500 & 550 & 600 & \\
\hline $765 \mathrm{C}-59 \mathrm{R}-3,116$ & 902.06 & NP & 180.7 & -48.2 & 6.4 & $6.40 \mathrm{E}-04$ & 4 & 450 & 500 & 550 & 600 & & \\
\hline $765 \mathrm{C}-59 \mathrm{R}-4,24$ & 902.64 & $\mathrm{~N}$ & 1.6 & -35.9 & 1.2 & $2.83 \mathrm{E}-03$ & 5 & 350 & 450 & 500 & 550 & 600 & \\
\hline & 903.01 & $\begin{array}{l}\text { RPP } \\
\text { RPP }\end{array}$ & $\begin{array}{l}158.6 \\
191.0\end{array}$ & 32.6 & & $1.08 \mathrm{E}-03$ & 1 & $\begin{array}{l}600 \\
650\end{array}$ & & & & & \\
\hline $\begin{array}{l}765 C-59 R-4,95 \\
765 C-59 R-4,136\end{array}$ & $\begin{array}{l}903.35 \\
903.76\end{array}$ & $\begin{array}{l}\text { RPP } \\
\text { RPP }\end{array}$ & $\begin{array}{l}191.0 \\
180.8\end{array}$ & $\begin{array}{l}22.9 \\
42.7\end{array}$ & & $\begin{array}{l}2.38 \mathrm{E}-04 \\
1.48 \mathrm{E}-03\end{array}$ & $i$ & $\begin{array}{l}650 \\
600\end{array}$ & & & & & \\
\hline $765 C-59 R-5,17$ & 904.07 & $R P$ & 164.3 & 31.2 & 4.3 & $9.21 \mathrm{E}-04$ & 4 & 500 & 550 & 600 & 650 & & \\
\hline $765 C-59 R-5,73$ & 904.63 & $\mathrm{~N}$ & 137.0 & -35.9 & 4.6 & $1.03 \mathrm{E}-03$ & 4 & 450 & 500 & 550 & 600 & & \\
\hline $765 C-59 R-6,13$ & 905.53 & NP & 337.6 & -46.3 & & $1.31 \mathrm{E}-03$ & 2 & 600 & 650 & & & & \\
\hline $765 \mathrm{C}-59 \mathrm{R}-6,42$ & 905.82 & $\mathrm{~N}$ & 0.7 & -43.0 & 1.3 & $3.46 \mathrm{E}-03$ & 5 & 350 & 450 & 500 & 550 & 600 & \\
\hline 765C-59R-6, 73 & 906.13 & $\mathrm{~N}$ & 354.6 & -31.6 & 1,8 & $2.87 \mathrm{E}-03$ & 4 & 450 & 500 & 550 & 600 & & \\
\hline $765 \mathrm{C}-60 \mathrm{R}-1,12$ & 907.62 & $\mathrm{~N}$ & 36.2 & -38.8 & 1.4 & $6.09 \mathrm{E}-03$ & 4 & 450 & 500 & 550 & 600 & & \\
\hline $765 \mathrm{C}-60 \mathrm{R}-1,49$ & 907.99 & $R$ & 163.0 & 23.3 & 4.3 & $1.76 \mathrm{E}-03$ & 3 & 550 & 600 & 650 & & & \\
\hline $765 \mathrm{C}-60 \mathrm{R}-1,76$ & 908.26 & NP & 18.5 & -46.4 & & $3.23 \mathrm{E}-03$ & 2 & 550 & 600 & & & & \\
\hline 765C-60R-1, 106 & 908.56 & $\mathrm{~N}$ & 356.8 & -39.9 & 2.0 & $1.75 \mathrm{E}-03$ & 3 & 550 & 600 & 650 & & & \\
\hline $765 \mathrm{C}-60 \mathrm{R}-1,138$ & 908.88 & $\begin{array}{l}\mathrm{R} \\
\mathrm{R}\end{array}$ & 152.8 & 26.0 & 4.8 & 1.62E-03 & 4 & 450 & 500 & 550 & 600 & & \\
\hline $\begin{array}{l}765 \mathrm{C}-60 \mathrm{R}-2,16 \\
765 \mathrm{C}-60 \mathrm{R}-2,54\end{array}$ & $\begin{array}{l}909.16 \\
909.54\end{array}$ & $\begin{array}{l}R \\
R P\end{array}$ & $\begin{array}{l}222.5 \\
176.8\end{array}$ & $\begin{array}{l}26.3 \\
22.7\end{array}$ & 4.9 & $\begin{array}{l}9.35 \mathrm{E}-04 \\
7.90 \mathrm{E}-04\end{array}$ & $\begin{array}{l}3 \\
2\end{array}$ & $\begin{array}{l}550 \\
550\end{array}$ & $\begin{array}{l}600 \\
600\end{array}$ & 650 & & & \\
\hline $765 \mathrm{C}-60 \mathrm{R}-2,83$ & 909.83 & RP & 57.8 & 19.4 & & 8.08E-04 & 2 & 600 & 650 & & & & \\
\hline $765 \mathrm{C}-60 \mathrm{R}-2,109$ & 910.09 & RPP & 247.7 & 23.9 & & $1.48 \mathrm{E}-04$ & 1 & 600 & & & & & \\
\hline $765 \mathrm{C}-60 \mathrm{R}-2.140$ & 910.40 & RP & 199.6 & 58.9 & & $5.17 \mathrm{E}-04$ & 2 & 600 & 650 & & & & \\
\hline $765 C-60 R-3,6$ & 910.56 & RPP & 201.6 & 48.1 & & 4.49E-04 & 1 & 600 & & & & & \\
\hline $765 C-60 R-3,57$ & 911.07 & $R ? ?$ & 190.8 & 36.7 & & $2.24 \mathrm{E}-04$ & 1 & 650 & & & & & \\
\hline 765C-60R-3, 99 & 911.49 & $\mathrm{~N}$ & 318.5 & -43.1 & 4.5 & $7.93 \mathrm{E}-04$ & 4 & 450 & 500 & 550 & 600 & & \\
\hline $765 \mathrm{C}-60 \mathrm{R}-4,13$ & 912.13 & R & 155.9 & 29.2 & 1.2 & 8.87E-04 & 3 & 550 & 600 & 650 & & & \\
\hline $765 \mathrm{C}-60 \mathrm{R}-4,47$ & 912.47 & $\mathrm{~N}$ & 346.4 & -43.5 & 4.2 & $1.17 \mathrm{E}-03$ & 4 & 450 & 500 & 550 & 600 & & \\
\hline $765 \mathrm{C}-60 \mathrm{~K}-4,74$ & 912.74 & NP & 315.7 & -56.4 & & 4.75E-04 & 2 & 600 & 650 & & & & \\
\hline $765 \mathrm{C}-60 \mathrm{R}-4,103$ & 913.03 & RP & 138.4 & 30.4 & & 3.90 E-04 & 2 & 550 & 600 & & & & \\
\hline $765 \mathrm{C}-60 \mathrm{R}-4,136$ & 913.36 & $\mathrm{~N}$ & $\begin{array}{r}4.8 \\
1581\end{array}$ & -48.0 & 2.7 & $\begin{array}{l}9.30 \mathrm{E}-04 \\
5.82 \mathrm{~F}-04\end{array}$ & $\frac{5}{2}$ & $\begin{array}{l}350 \\
550\end{array}$ & $\begin{array}{l}450 \\
600\end{array}$ & 500 & 550 & 600 & \\
\hline $\begin{array}{l}765 \mathrm{C}-60 \mathrm{R}-5,21 \\
765 \mathrm{C}-60 \mathrm{R}-5,57\end{array}$ & $\begin{array}{l}913.71 \\
914.07\end{array}$ & $\begin{array}{l}R P \\
N\end{array}$ & $\begin{array}{l}158.1 \\
357.9\end{array}$ & $\begin{array}{r}44.8 \\
-41.4\end{array}$ & 2.6 & $\begin{array}{l}5.82 \mathrm{E}-04 \\
9.80 \mathrm{E}-04\end{array}$ & $\begin{array}{l}2 \\
3\end{array}$ & $\begin{array}{l}550 \\
550\end{array}$ & $\begin{array}{l}600 \\
600\end{array}$ & 650 & & & \\
\hline $765 C-60 R-5,105$ & 914.55 & $\mathrm{R}$ & 170.7 & 44.7 & 3.6 & 2.35E-03 & 4 & 450 & 560 & 550 & 600 & & \\
\hline $765 C-61 R-1,18$ & 917.08 & $\mathrm{~N}$ & 272.4 & -41.1 & 4.2 & $1.90 \mathrm{E}-03$ & 5 & 450 & 500 & 550 & 600 & 650 & \\
\hline $765 C-61 \mathrm{R}-1,40$ & 917.30 & NP & 329.7 & -51.9 & & $4.68 \mathrm{E}-03$ & 2 & 550 & 600 & & & & \\
\hline $765 C-61 R-1,73$ & 917.63 & $\mathrm{~N}$ & 51.7 & -56.8 & 3.6 & 2.99E-03 & 4 & 500 & 550 & 600 & 650 & & \\
\hline $765 C-61 R-1,99$ & 917.89 & NP & 264.4 & -56.6 & 5.8 & $2.02 \mathrm{E}-03$ & 4 & 450 & 500 & 550 & 600 & & \\
\hline $765 C-61 R-1,140$ & 918.30 & RPP & 95.7 & 62.7 & & $3.15 \mathrm{E}-03$ & 2 & 550 & 600 & & & & \\
\hline $765 \mathrm{C}-61 \mathrm{R}-2,12$ & 918.52 & INT & 249.5 & -70.6 & & $6.64 \mathrm{E}-04$ & 1 & 600 & & & & & \\
\hline $765 \mathrm{C}-61 \mathrm{R}-2,36$ & 918.76 & N?? & 60.5 & -53.2 & & $3.47 \mathrm{E}-03$ & 2 & 550 & 600 & & & & \\
\hline $765 C-61 R-2,65$ & 919.05 & $\cdots p$ & 11.3 & -39.5 & & $1.16 \mathrm{E}-03$ & 1 & 600 & & & & & \\
\hline 765C-61R-2, 90 & 919.30 & INT & 175.9 & -14.3 & & $6.80 \mathrm{E}-07$ & 1 & 600 & & & & & \\
\hline $765 C-61 R-2,141$ & 919.81 & NPP & 141.7 & -54.6 & 5.5 & $5.88 \mathrm{E}-03$ & 4 & 450 & 500 & 550 & 600 & & \\
\hline $765 C-61 R-3,9$ & 919.99 & $\mathrm{~N}$ & 315.1 & -52.2 & 2.6 & $7.28 \mathrm{E}-03$ & 5 & 350 & 450 & 500 & 550 & 600 & \\
\hline $765 C-61 R-3,49$ & 920.39 & NPP & 319.6 & -52.5 & 3.2 & $6.48 \mathrm{E}-03$ & 5 & 350 & 450 & 500 & 550 & 600 & \\
\hline $765 C-61 R-4,11$ & 921.51 & $\mathrm{~N}$ & 323.4 & -42.9 & 3.0 & $5.54 \mathrm{E}-03$ & 5 & 350 & 450 & 500 & 550 & 600 & \\
\hline $765 C \cdot 61 R \cdot 4,36$ & 921.76 & $\mathrm{~N}$ & 329.3 & -45.7 & 1.6 & $9.45 \mathrm{E}-03$ & 6 & 250 & 350 & 450 & 500 & 550 & 600 \\
\hline $765 C-61 \mathrm{R}-4,68$ & 922.08 & NP & 315.2 & -44.6 & & $4.86 \mathrm{E}-03$ & 2 & 550 & 600 & & & & \\
\hline $765 C-61 R-5,5$ & 922.95 & $\mathrm{~N}$ & 245.6 & -48.6 & 3.4 & $6.36 \mathrm{E}-03$ & 4 & 450 & 500 & 550 & 600 & & \\
\hline $765 C-61 R-5,42$ & 923.32 & $\mathrm{~N}$ & 4.1 & -46.1 & 3.4 & $4.82 \mathrm{E}-03$ & 4 & 450 & 500 & 550 & 600 & & \\
\hline $765 C-61 R-5,67$ & 923.57 & NP & 12.5 & -45.9 & 5.3 & $1.66 \mathrm{E}-03$ & 3 & 550 & 600 & 650 & & & \\
\hline 765C-61R-5, 99 & 923.89 & RP & 113.4 & -13.7 & & $1.94 \mathrm{E}-03$ & 2 & 500 & 550 & & & & \\
\hline $765 C-61$ R-5, 140 & 924.30 & RP & 182.0 & 51.9 & 6.4 & $1.82 \mathrm{E}-03$ & 4 & 500 & 550 & 600 & 650 & & \\
\hline $765 \mathrm{C}-62 \mathrm{R}-1,12$ & 926.01 & RPP & 93.4 & 34.0 & 5.0 & $1.86 \mathrm{E}-03$ & 3 & 500 & 550 & 600 & & & \\
\hline $765 \mathrm{C}-62 \mathrm{R}-1,36$ & 926.76 & RP & 284.9 & 34.8 & 6.8 & 1.47E-03 & 3 & 550 & 600 & 650 & & & \\
\hline $765 \mathrm{C}-62 \mathrm{R}-1,70$ & 927.10 & $\mathrm{~N}$ & 351.3 & -32.2 & 2.2 & 4.30E-03 & 4 & 450 & 500 & 550 & 600 & & \\
\hline $765 C-62 R-1,111$ & 927.51 & RP & 318.8 & 49.3 & & $9.10 \mathrm{E}-04$ & 2 & 550 & 600 & & & & \\
\hline $765 C-62 R-1,150$ & 927.90 & $R$ & 158.2 & 50.0 & 0.7 & $1.92 \mathrm{E}-03$ & 3 & 500 & 550 & 600 & & & \\
\hline $765 C-62 R-2,16$ & 928.06 & INT & 357.1 & -38.9 & & $1.20 \mathrm{E}-03$ & 1 & 600 & & & & & \\
\hline $765 C-62 R-2,54$ & 928.44 & RP & 219.4 & 50.1 & 5.5 & $1.68 \mathrm{E}-03$ & 3 & 500 & 550 & 600 & & & \\
\hline $765 C-62 R-2,81$ & 928.71 & RPP & 176.1 & 36.6 & 3.4 & $1.81 \mathrm{E}-03$ & 4 & 500 & 550 & 600 & 650 & & \\
\hline 765C-62R-2, 109 & 928.99 & RPP & 107.9 & 41.5 & & $2.16 \mathrm{E}-03$ & 2 & 550 & 600 & & & & \\
\hline $765 C-62 R-2,145$ & 929.35 & NPP & 103.9 & -47.4 & 2.8 & $5.12 \mathrm{E}-03$ & 3 & 500 & 550 & 600 & & & \\
\hline $765 C-62 R-3,8$ & 929.48 & $\mathrm{~N}$ & 59.6 & -44.5 & 2.1 & $6.34 \mathrm{E}-03$ & 4 & 450 & 500 & 550 & 600 & & \\
\hline $765 C-62 R-3,33$ & 929.73 & NPP & 237.5 & -45.3 & 4.7 & $7.80 \mathrm{E}-03$ & 4 & 450 & 500 & 550 & 600 & & \\
\hline $765 C-62 R-3,59$ & 929.99 & $N$ & 36.2 & -35.2 & 1.6 & $6.52 \mathrm{E}-03$ & 4 & 450 & 500 & 550 & 600 & & \\
\hline $765 C-62 R-3,85$ & 930.25 & RP & 154.5 & 40.4 & 7.8 & $5.77 \mathrm{E}-03$ & 4 & 450 & 500 & 550 & 600 & & \\
\hline $765 C-62 R-3,125$ & 930.65 & $N$ & 282.4 & -48.7 & 6.5 & $8.38 \mathrm{E}-03$ & 4 & 450 & 500 & 550 & 600 & & \\
\hline $765 \mathrm{C}-62 \mathrm{R}-3,151$ & 930.91 & $\mathbf{R}$ & 177.9 & 26.8 & 3.1 & $3.32 \mathrm{E}-03$ & 3 & 500 & 550 & 600 & & & \\
\hline $765 C-62 R-4,22$ & 931.12 & NPP & 110.2 & -32.8 & & $1.64 \mathrm{E}-03$ & 2 & 550 & 600 & & & & \\
\hline
\end{tabular}




\begin{tabular}{|c|c|c|c|c|c|c|c|c|c|c|c|c|c|c|c|}
\hline \multirow{2}{*}{$\begin{array}{l}\text { Core, section, } \\
\text { interval }(\mathrm{cm})\end{array}$} & \multirow{2}{*}{$\begin{array}{l}\text { Meter level } \\
\text { (mbsf) }\end{array}$} & \multirow[b]{2}{*}{ Polarity } & \multicolumn{3}{|c|}{ Characteristic direction } & \multirow{2}{*}{$\begin{array}{l}\text { Mean intensity } \\
(\mathrm{A} / \mathrm{m})\end{array}$} & \multicolumn{9}{|c|}{ Demagnetization steps used in least-squares } \\
\hline & & & Declination & Inclination & Error & & Total & & & & Selec & d level & $\left({ }^{\circ} \mathrm{C}\right)$ & & \\
\hline 261-21R-1, 44 & 332.94 & $\mathrm{~N}$ & 125.4 & -44.4 & 0.4 & $1.58 \mathrm{E}-02$ & 4 & 450 & 500 & 550 & 600 & & & & \\
\hline $261-22 R-2,20$ & 343.76 & $\mathrm{~N}$ & 272.2 & -62.8 & 1.7 & $1.29 \mathrm{E}-02$ & 4 & 450 & 500 & 550 & 600 & & & & \\
\hline $261-22 \mathrm{R}-3,14$ & 345.14 & $\mathrm{~N}$ & 315.0 & -53.2 & 1.5 & $1.81 \mathrm{E}-02$ & 6 & 350 & 400 & 450 & 500 & 550 & 600 & & \\
\hline $261-22 R-4,11$ & 346.61 & $\mathrm{~N}$ & 32.8 & -62.9 & 2.0 & $2.11 \mathrm{E}-02$ & 7 & 300 & 350 & 400 & 450 & 500 & 550 & 600 & \\
\hline $261-22 R-5,39$ & 348.39 & $\mathrm{~N}$ & 35.9 & -57.0 & 1.8 & $9.56 \mathrm{E}-03$ & 5 & 400 & 450 & 500 & 550 & 600 & & & \\
\hline $261-23 R-1,64$ & 361.64 & $\mathrm{~N}$ & 86.2 & -60.9 & 3.2 & $1.84 \mathrm{E}-02$ & 5 & 400 & 450 & 500 & 550 & 600 & & & \\
\hline $261-23 R-2,129$ & 362.79 & R & 341.1 & 59.6 & 2.2 & $6.26 \mathrm{E}-03$ & 4 & 450 & 500 & 550 & 600 & & & & \\
\hline 261-23R-3, 75 & 364.75 & R & 261.3 & 48.7 & 2.1 & $1.19 \mathrm{E}-02$ & 5 & 450 & 450 & 500 & 550 & 600 & & & \\
\hline $261-24 \mathrm{R}-1,86$ & 380.86 & R & 256.8 & 51.5 & 2,7 & $2.42 \mathrm{E}-02$ & 7 & 300 & 350 & 400 & 450 & 500 & 550 & 600 & \\
\hline $261-24 \mathrm{R}-2,43$ & 381.73 & $\mathrm{~N}$ & 36.9 & -52.3 & 3.5 & $1.34 \mathrm{E}-02$ & 6 & 350 & 400 & 450 & 500 & 550 & 600 & & \\
\hline $261-25 R-1,139$ & 399.39 & $\mathrm{~N}$ & 273.2 & -62.7 & 2.3 & $2.63 \mathrm{E}-02$ & 5 & 400 & 450 & 500 & 550 & 600 & & & \\
\hline $261-25 R-2,6$ & 400.56 & NP & 239.7 & -62.8 & 5.7 & $1.81 \mathrm{E}-02$ & 6 & 300 & 400 & 450 & 500 & 550 & 600 & & \\
\hline $261-25 R-3,13$ & 402.13 & $\mathrm{~N}$ & 153.9 & -52.4 & 2.7 & $1.88 \mathrm{E}-02$ & 6 & 350 & 400 & 450 & 500 & 550 & 600 & & \\
\hline $261-26 \mathrm{R}-1,63$ & 418.63 & $\mathrm{RP}$ & 45.7 & 32.2 & 0.3 & $1.19 \mathrm{E}-02$ & 2 & 450 & 500 & Tied & & & & & \\
\hline $261-26 R-1,96$ & 418.96 & RP & 354.2 & 48.9 & 0.8 & $2.25 \mathrm{E}-02$ & 2 & 450 & 500 & Tied & & & & & \\
\hline $261-26 \mathrm{R}-1,123$ & 419.23 & RP & 165.4 & 23.9 & 5.7 & $2.82 \mathrm{E}-02$ & 4 & 325 & 400 & 450 & 500 & & & & \\
\hline $261-27 R-1,34$ & 437.34 & RP & 260.9 & 45.2 & 1.1 & $2.51 \mathrm{E}-02$ & 2 & 450 & 500 & Tied & & & & & \\
\hline $261-27 R-1,60$ & 437.60 & RP & 11.1 & 59.5 & 0.6 & $3.79 \mathrm{E}-03$ & 3 & 400 & 450 & 500 & Tied & & & & \\
\hline $261-27 R-1,111$ & 438.11 & $\mathrm{~N}$ & 312.3 & -62.2 & 1.9 & $6.47 \mathrm{E}-03$ & 8 & 250 & 300 & 350 & 400 & 450 & 500 & 550 & 600 \\
\hline $261-27 R-2,3$ & 438.53 & $\mathrm{~N}$ & 341.7 & -63.5 & 2.1 & $1.51 \mathrm{E}-02$ & 3 & 500 & 550 & 600 & Tied & & & & \\
\hline $261-27 R-2,44$ & 438.94 & $\mathrm{~N}$ & 319.3 & -50.6 & 1.5 & $5.54 \mathrm{E}-03$ & 4 & 325 & 400 & 450 & 500 & & & & \\
\hline $261-27 R-2,96$ & 439.46 & $\mathrm{~N}$ & 135.2 & -61.5 & 2.2 & $3.17 \mathrm{E}-02$ & 3 & 400 & 450 & 500 & & & & & \\
\hline 261-28R-1, 63 & 447.13 & $\mathrm{~N}$ & 181.4 & -55.2 & 3.0 & $7.13 \mathrm{E}-03$ & 4 & 325 & 400 & 450 & 500 & & & & \\
\hline $261-28 \mathrm{R}-1,137$ & 447.87 & $\mathrm{RP}$ & 3.9 & 57.1 & 1.5 & 1.05E-02 & 2 & 450 & 500 & Tied & & & & & \\
\hline $261-28 R-2,20$ & 448.20 & RP & 275.0 & 63.5 & 0.7 & $4.99 \mathrm{E}-03$ & 2 & 450 & 500 & Tied & & & & & \\
\hline $261-28 R-2,119$ & 449.19 & $\mathrm{~N}$ & 186.4 & -54.0 & 4.9 & $1.88 \mathrm{E}-02$ & 4 & 325 & 400 & 450 & 500 & & & & \\
\hline 261-28R-3, 3 & 449.53 & $\mathrm{~N}$ & 259.3 & -64.7 & 3.4 & $1.31 \mathrm{E}-02$ & 4 & 325 & 400 & 450 & 500 & & & & \\
\hline $261-28 R-3,99$ & 450.49 & RP & 334.6 & 52.3 & 6.3 & $2.75 \mathrm{E}-03$ & 3 & 400 & 450 & 500 & & & & & \\
\hline $261-28 R-3,126$ & 450.76 & N?? & 297.1 & -43.7 & & $1.54 \mathrm{E}-03$ & 1 & 325 & Org & & & & & & \\
\hline $261-28 R-4,12$ & 451.12 & NPP & 1.5 & -69.4 & 1.9 & $2.12 \mathrm{E}-02$ & 3 & 400 & 450 & 500 & & & & & \\
\hline $261-29 \mathrm{R}-1,93$ & 466.43 & INT & 346.8 & -69.6 & & $2.70 \mathrm{E}-05$ & 1 & 350 & Org & & & & & & \\
\hline $261-29 \mathrm{R}-1,122$ & 466.72 & NPP & 80.5 & -48.7 & & $6.43 \mathrm{E}-03$ & 2 & 450 & 500 & Tied & & & & & \\
\hline $261-29 \mathrm{R}-2,140$ & 466.90 & $\mathrm{~N}$ & 68.0 & -63.4 & 2.6 & $2.43 \mathrm{E}-02$ & 3 & 400 & 450 & 500 & & & & & \\
\hline $261-29 \mathrm{R}-2,46$ & 467.46 & $\mathrm{~N}$ & 7.9 & -52.5 & 4.3 & $3.70 \mathrm{E}-03$ & 6 & 350 & 400 & 450 & 500 & 550 & 600 & & \\
\hline $261-29 \mathrm{R}-3,61$ & 469.11 & $\mathrm{~N}$ & 37.0 & -58.9 & 1.3 & $2.72 \mathrm{E}-03$ & 4 & 325 & 400 & 450 & 500 & & & & \\
\hline $261-29 \mathrm{R}-3,148$ & 469.98 & RP & 41.5 & 51.0 & & $1.10 \mathrm{E}-03$ & 2 & 450 & 500 & Tied & & & & & \\
\hline $261-30 \mathrm{R}-2,52$ & 486.52 & $\mathrm{~N}$ & 342.2 & -50.4 & 1.8 & $1.89 \mathrm{E}-03$ & 4 & 325 & 400 & 450 & 500 & & & & \\
\hline 261-30R-2, 93 & 486.93 & $\mathrm{RP}$ & 258.0 & 47.8 & 38.2 & $1.55 \mathrm{E}-03$ & 3 & 400 & 450 & 500 & & & & & \\
\hline $261-30 \mathrm{R}-3,41$ & 487.91 & $\mathrm{RP}$ & 93.3 & 47.2 & 8.6 & $2.07 \mathrm{E}-03$ & 3 & 400 & 450 & 500 & & & & & \\
\hline $261-30 \mathrm{R}-3,114$ & 488.64 & RP & 75.7 & 64.3 & & $8.95 \mathrm{E}-04$ & 2 & 450 & 500 & Tied & & & & & \\
\hline $261-30 \mathrm{R}-3,146$ & 488.96 & $\mathbf{R}$ & 33.1 & 41.3 & 4.2 & $2.88 \mathrm{E}-04$ & 3 & 400 & 450 & 500 & & & & & \\
\hline $261-30 \mathrm{R}-4,4$ & 489.04 & $\mathrm{R}$ & 23.4 & 56.7 & 4.5 & $1.07 \mathrm{E}-03$ & 3 & 400 & 450 & 500 & & & & & \\
\hline $261-30 \mathrm{R}-4,38$ & 489.38 & RPP & 253.8 & 20.0 & & $1.01 \mathrm{E}-03$ & 2 & 450 & 500 & Tied & & & & & \\
\hline 261-31R-2, 37 & 505.37 & $\mathrm{~N}$ & 52.8 & -55.8 & 2.8 & $1.26 \mathrm{E}-02$ & 3 & 400 & 450 & 500 & & & & & \\
\hline $261-31 \mathrm{R}-2,60$ & 505.60 & $\mathrm{~N}$ & 297.3 & -54.0 & 1.4 & $6.45 \mathrm{E}-03$ & 3 & 400 & 450 & 500 & & & & & \\
\hline $261-3 \mid$ R- 2,108 & 506.08 & $\mathrm{~N}$ & 246.6 & -53.8 & 5.1 & $3.91 \mathrm{E}-03$ & 8 & 250 & 300 & 350 & 400 & 450 & 500 & 550 & 600 \\
\hline $261-31 R-3,14$ & 506.64 & $\mathrm{~N}$ & 350.7 & -57.2 & 0.8 & $1.81 \mathrm{E}-03$ & 3 & 400 & 450 & 500 & & & & & \\
\hline $261-31$ R-3, 69 & 507.19 & RP & 184.7 & 54.4 & 0.9 & $5.33 \mathrm{E}-03$ & 2 & 450 & 500 & Tied & & & & & \\
\hline $261-3 \mid R-3,123$ & 507.73 & N?? & 304.0 & -55.5 & & $8.84 \mathrm{E}-04$ & 2 & 450 & 500 & & & & & & \\
\hline 26$]-31 R-4,27$ & 508.27 & $\mathrm{~N}$ ?? & 259.4 & -58.0 & 3.7 & $2.42 \mathrm{E}-03$ & 3 & 400 & 450 & 500 & & & & & \\
\hline $261-31 R-4,56$ & 508.56 & $\mathrm{~N}$ & 25.7 & -46.8 & 2.0 & $1.19 \mathrm{E}-03$ & 3 & 400 & 450 & 500 & & & & & \\
\hline $261-31 R-5,141$ & 510.91 & RP & 339.2 & 74.6 & 1.3 & $1.76 \mathrm{E}-03$ & 2 & 450 & 500 & Tied & & & & & \\
\hline $261-32 R-2,20$ & 524.20 & RP & 334.8 & 56.7 & 10.3 & $1.25 \mathrm{E}-03$ & 3 & 400 & 450 & 500 & & & & & \\
\hline $261-32 R-2,36$ & 524.36 & RP & 129.1 & 53.7 & 2.0 & $7.42 \mathrm{E}-04$ & 2 & 450 & 500 & Tied & & & & & \\
\hline $261-32 \mathrm{R}-2,69$ & 524.69 & $N$ & 309.8 & -48.8 & 2.7 & $7.53 \mathrm{E}-03$ & 4 & 325 & 400 & 450 & 500 & & & & \\
\hline 261-32R-3, 8 & 535.58 & RP & 86.4 & 70.4 & & $2.72 \mathrm{E}-03$ & 2 & 450 & 500 & Tied & & & & & \\
\hline $261-33 R-1,9$ & 532.09 & $\mathrm{R}$ ?? & 145.0 & 44.3 & & $8.40 \mathrm{E}-04$ & 2 & 450 & 500 & & & & & & \\
\hline $261-33 R-1,68$ & 532.68 & RP & 169.8 & 21.2 & 7.9 & $6.71 \mathrm{E}-04$ & 3 & 400 & 450 & 500 & & & & & \\
\hline
\end{tabular}

Leg 123, Site 766

\begin{tabular}{|c|c|c|c|c|c|c|c|c|c|c|c|c|c|c|c|c|}
\hline \multirow{2}{*}{$\begin{array}{l}\text { Core, section, } \\
\text { interval }(\mathrm{cm})\end{array}$} & \multirow{2}{*}{$\begin{array}{c}\text { Meter level } \\
\text { (mbsf) }\end{array}$} & \multirow[b]{2}{*}{ Polarity } & \multicolumn{3}{|c|}{ Characteristic direction } & \multirow{2}{*}{$\begin{array}{c}\text { Mean intensity } \\
(\mathrm{A} / \mathrm{m})\end{array}$} & \multicolumn{10}{|c|}{ Demagnetization steps used in least-squares } \\
\hline & & & Declination & Inclination & Error & & Total & 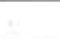 & & Selected & Levels & $\mathrm{nT}$; or & legrees & $f>100$ & & \\
\hline $766 \mathrm{~A}-26 \mathrm{R}-1,17$ & 239.47 & $\mathrm{~N}$ & 108.9 & -48.4 & 0.9 & $3.68 \mathrm{E}-02$ & 5 & 7.5 & 10.0 & 20.0 & 30.0 & 40.0 & & & & \\
\hline $766 \mathrm{~A}-26 \mathrm{R}-1,89$ & 240.19 & $\mathrm{~N}$ & 265.5 & -55.8 & 2.6 & I. $59 \mathrm{E}-02$ & 7 & 15.0 & 20.0 & 25.0 & 30.0 & 40.0 & 300 & 400 & & \\
\hline $766 \mathrm{~A}-26 \mathrm{R}-2,90$ & 241.70 & $\mathrm{~N}$ & 233.5 & -56.4 & 1.5 & $2.27 \mathrm{E}-02$ & 4 & 15.0 & 20.0 & 30.0 & 40.0 & & & & & \\
\hline $766 \mathrm{~A}-26 \mathrm{R}-2,141$ & 242.21 & $\mathrm{R}$ ?? & 24.6 & 37.1 & & $1.10 \mathrm{E}-03$ & 1 & 45.0 & Org & & & & & & & \\
\hline $766 \mathrm{~A}-26 \mathrm{R}-3,29$ & 242.59 & $\mathrm{~N}$ & 323.4 & -55.1 & 1.9 & $8.41 \mathrm{E}-03$ & 4 & 15.0 & 20.0 & 30.0 & 40.0 & & & & & \\
\hline $766 \mathrm{~A}-26 \mathrm{R}-3,80$ & 243.10 & NP & 72.1 & -53.7 & 6.3 & $1.30 \mathrm{E}-03$ & 4 & 10.0 & 20.0 & 30.0 & 40.0 & & & & & \\
\hline 766A-26R-CC, 6 & 243.75 & $\mathrm{~N}$ & 72.2 & -54.2 & 2.7 & $1.02 \mathrm{E}-03$ & 4 & 20.0 & 30.0 & 35.0 & 40.0 & & & & & \\
\hline $766 \mathrm{~A}-27 \mathrm{R}-1,13$ & 249.03 & $\mathrm{~N}$ & 224.9 & -42.2 & 3.3 & 4.72E-04 & 4 & 15.0 & 20.0 & 30.0 & 40.0 & Org & & & & \\
\hline $766 \mathrm{~A}-27 \mathrm{R}-1,62$ & 249.52 & RP & 29.4 & 34.4 & 1.4 & $1.39 \mathrm{E}-04$ & 3 & 30.0 & 45.0 & 40.0 & Org & & & & & \\
\hline $766 \mathrm{~A}-27 \mathrm{R}-1,121$ & 250.11 & $N$ & 351.4 & -53.7 & 2.0 & $6.46 \mathrm{E}-04$ & 4 & 10.0 & 20.0 & 30.0 & 35.0 & Org & & & & \\
\hline $766 \mathrm{~A}-27 \mathrm{R}-2,5$ & 250.45 & RP & 165.5 & 41.4 & 1.4 & $3.19 \mathrm{E}-04$ & 2 & 35.0 & 40.0 & Org & & & & & & \\
\hline $766 \mathrm{~A}-27 \mathrm{R}-2,52$ & 250.92 & R & 165.6 & 42.3 & 1.6 & $2.21 \mathrm{E}-04$ & 3 & 30.0 & 35.0 & 40.0 & Org & & & & & \\
\hline 766A-27R-2, 102 & 251.42 & $\mathbf{R}$ & 242.6 & 42.3 & 2.6 & 8.44E-04 & 4 & 15.0 & 20.0 & 30.0 & 40.0 & Org & & & & \\
\hline $766 \mathrm{~A}-27 \mathrm{R}-3,6$ & 251.86 & NP & 307.5 & -50.5 & 6.2 & 1.54E-04 & 3 & 20.0 & 30.0 & 40.0 & Org & & & & & \\
\hline $766 \mathrm{~A}-27 \mathrm{R}-\mathrm{CC}, 4$ & 251.94 & RP & 13.2 & 38.7 & 11.6 & $2.61 \mathrm{E}-04$ & 9 & 10.0 & 15.0 & 20.0 & 25.0 & 30.0 & 40.0 & 45.0 & 300 & 400 \\
\hline $766 \mathrm{~A}-28 \mathrm{R}-1,13$ & 258.73 & $\mathrm{~N}$ & 32.6 & -45.8 & 4.8 & $5.71 \mathrm{E}-04$ & 6 & 10.0 & 20.0 & 30.0 & 35.0 & 40.0 & 45.0 & & & \\
\hline
\end{tabular}




\begin{tabular}{|c|c|c|c|c|c|c|c|c|c|c|c|c|}
\hline tion, & vel & & Charac & eristic directi & & & & & Dema & netizat & on step & used $\mathrm{i}$ \\
\hline interval $(\mathrm{cm})$ & (mbsf) & Polarity & Declination & Inclination & Error & $(\mathrm{A} / \mathrm{m})$ & Total & & & Selected & Levels & $\mathrm{mT}$; or \\
\hline $766 \mathrm{~A}-28 \mathrm{R}-1,54$ & 259.14 & $\mathbf{R}$ & 169.7 & 46.4 & 0.8 & 6.67E-04 & 4 & 15.0 & 20.0 & 30.0 & 40.0 & Org \\
\hline 766A-28R-1, 113 & 259.73 & $\mathbf{R}$ & 327.1 & 47.5 & 1.4 & $5.11 \mathrm{E}-04$ & 4 & 30.0 & 35.0 & 40.0 & 45.0 & Org \\
\hline $766 \mathrm{~A}-28 \mathrm{R}-2,31$ & 260.41 & $\mathbf{R}$ & 226.2 & 36.2 & 2.2 & 3.89E-04 & 4 & 30.0 & 35.0 & 45.0 & 40.0 & Org \\
\hline $766 \mathrm{~A}-28 \mathrm{R}-2,107$ & 261.17 & $\mathbf{R}$ & 136.2 & 38.7 & 2.7 & $2.20 \mathrm{E}-04$ & 3 & 20.0 & 30.0 & 40.0 & Org & \\
\hline $766 \mathrm{~A}-28 \mathrm{R}-3,31$ & 261.91 & RP & 58.4 & 41.9 & 8.5 & $1.85 \mathrm{E}-04$ & 7 & 20.0 & 25.0 & 30.0 & 40.0 & 45.0 \\
\hline $766 \mathrm{~A}-28 \mathrm{R}-3,104$ & 262.64 & RP & 92.8 & 35.6 & 3.3 & $1.50 \mathrm{E}-04$ & 3 & 20.0 & 40.0 & 45.0 & Org & \\
\hline $766 \mathrm{~A}-28 \mathrm{R}-4,46$ & 263.56 & $\mathbf{R}$ & 90.3 & 43.2 & 1.8 & $1.89 \mathrm{E}-04$ & 4 & 15.0 & 20.0 & 30.0 & 40.0 & Org \\
\hline $766 \mathrm{~A}-28 \mathrm{R}-4,97$ & 264.07 & $\mathrm{R}$ & 72.8 & 46.9 & 2.0 & $2.98 \mathrm{E}-04$ & 4 & 15.0 & 20.0 & 30.0 & 40.0 & Org \\
\hline $766 \mathrm{~A}-28 \mathrm{R}-4,148$ & 264.58 & $\mathbf{R}$ & 311.4 & 49.4 & 2.3 & $1.30 \mathrm{E}-04$ & 3 & 30.0 & 40.0 & 45.0 & Org & \\
\hline 766A-28R-5, 54 & 265.14 & R & 200.0 & 48.7 & 1.2 & $2.16 \mathrm{E}-04$ & 3 & 20.0 & 35.0 & 40.0 & Org & \\
\hline 766A-28R-5, 102 & 265.62 & R & 332.4 & 60.6 & 2.6 & $2.17 \mathrm{E}-04$ & 4 & 20.0 & 30.0 & 40.0 & 45.0 & Org \\
\hline $766 \mathrm{~A}-28 \mathrm{R}-6,25$ & 266.35 & $\mathbf{R}$ & 293.0 & 33.4 & 2.4 & 2.81 E-04 & 4 & 30.0 & 35.0 & 40.0 & 45.0 & Org \\
\hline $766 \mathrm{~A}-28 \mathrm{R}-6,113$ & 267.22 & $\mathbf{R}$ & 5.3 & 47.3 & 3.1 & $1.65 \mathrm{E}-04$ & 4 & 15.0 & 20.0 & 30.0 & 40.0 & Org \\
\hline 766A-28R-7, 18 & 267.78 & RP & 7.9 & 43.2 & 2.1 & $1.37 \mathrm{E}-04$ & 2 & 35.0 & 40.0 & Org & & \\
\hline 766A-28R-CC, 5 & 267.89 & RPP & 82.5 & 42.2 & 11.2 & $1.25 \mathrm{E}-04$ & 4 & 30.0 & 35.0 & 40.0 & 45.0 & Org \\
\hline 766A-29R-1, 15 & 268.45 & RP & 198.2 & 47.9 & 4.4 & 2.03E-04 & 4 & 20.0 & 30.0 & 40.0 & 45.0 & Org \\
\hline $766 \mathrm{~A}-29 \mathrm{R}-1,77$ & 269.07 & $R$ & 320.3 & 42.9 & 3.0 & $2.16 \mathrm{E}-04$ & 4 & 15.0 & 20.0 & 30.0 & 40.0 & Org \\
\hline $766 \mathrm{~A}-29 \mathrm{R}-1,136$ & 269.66 & $\mathbf{R}$ & 220.2 & 42.2 & 2.8 & 2.01E-04 & 4 & 20.0 & 30.0 & 35.0 & 40.0 & Org \\
\hline $766 \mathrm{~A}-29 \mathrm{R}-2,10$ & 269.80 & INT & 318.3 & -43.7 & 1.5 & 1.15E-04 & 2 & 30.0 & 40.0 & Org & & \\
\hline $766 \mathrm{~A}-29 \mathrm{R}-2,82$ & 270.62 & RP & 241.7 & 41.4 & 2.0 & $8.68 \mathrm{E}-05$ & 2 & 35.0 & 40.0 & Org & & \\
\hline $766 \mathrm{~A}-29 \mathrm{R}-2,113$ & 270.93 & $\mathbf{R}$ & 325.9 & 55.0 & 6.1 & $5.85 \mathrm{E}-05$ & 7 & 20.0 & 25.0 & 30.0 & 35.0 & 40.0 \\
\hline 766A-29R-3, 29 & 271.59 & RP & 355.3 & 39.4 & 5.5 & $1.38 \mathrm{E}-04$ & 4 & 30.0 & 35.0 & 40.0 & 45.0 & Org \\
\hline $766 \mathrm{~A}-29 \mathrm{R}-3,124$ & 272.06 & R?? & 309.7 & 22.6 & 22.1 & $1.30 \mathrm{E}-04$ & 4 & 30.0 & 35.0 & 40.0 & 45.0 & Org \\
\hline $766 \mathrm{~A}-29 \mathrm{R}-3,76$ & 272.56 & RP & 229.2 & 52.1 & 11.7 & 1.84E-04 & 5 & 20.0 & 30.0 & 40.0 & 42.5 & 45.0 \\
\hline $766 \mathrm{~A}-29 \mathrm{R}-4,9$ & 272.89 & RP & 3.3 & 39.8 & 2.5 & $3.35 \mathrm{E}-04$ & 3 & 30.0 & 35.0 & 40.0 & Org & \\
\hline 766 A-29R-4, 63 & 273.43 & $R$ & 118.2 & 48.5 & 4.1 & 3.05E-04 & 4 & 15.0 & 20.0 & 30.0 & 40.0 & Org \\
\hline $766 \mathrm{~A}-29 \mathrm{R}-4,107$ & 273.87 & RPP & 281,5 & 35.1 & & $2.73 \mathrm{E}-04$ & 1 & 40.0 & Org & & & \\
\hline $766 \mathrm{~A}-29 \mathrm{R}-4,144$ & 274.24 & $\mathbf{R}$ & 105.4 & 56.5 & 1.7 & $2.14 \mathrm{E}-04$ & 3 & 15.0 & 20.0 & 30.0 & Org & \\
\hline 766A-30R-1, 11 & 278.01 & R & 92.5 & 38.0 & 2.6 & $3.22 \mathrm{E}-04$ & 3 & 30.0 & 35.0 & 40.0 & Org & \\
\hline 766A-30R-1, 23 & 278.13 & $\mathrm{R}$ ?? & 337.4 & 25.2 & 16.4 & $6.02 \mathrm{E}-04$ & 4 & 20.0 & 30.0 & 40.0 & 45.0 & \\
\hline 766A-30R-2, 20 & 279.60 & RP & 331.9 & 39.1 & 10.9 & $1.56 \mathrm{E}-04$ & 4 & 20.0 & 30.0 & 40.0 & 45.0 & Org \\
\hline $766 \mathrm{~A}-30 \mathrm{R}-2,131$ & 280.71 & $\mathbf{R}$ & 177.1 & 47.7 & 2.2 & 2.37E-04 & 4 & 30.0 & 35.0 & 40.0 & 45.0 & Org \\
\hline $766 \mathrm{~A}-30 \mathrm{~K}-2,143$ & 280.83 & RP & 177.4 & 46.9 & 1.5 & $1.86 \mathrm{E}-04$ & 2 & 30.0 & 40.0 & Org & & \\
\hline $766 \mathrm{~A}-30 \mathrm{R}-3,57$ & 281.47 & RPP & 137.2 & 47.4 & 7.3 & $1.56 \mathrm{E}-04$ & 2 & 35.0 & 40.0 & Org & & \\
\hline $766 \mathrm{~A}-30 \mathrm{R}-3,105$ & 281.95 & RP & 244.3 & 41.5 & 6.5 & $1.86 \mathrm{E}-04$ & 3 & 30.0 & 40.0 & 45.0 & Org & \\
\hline $766 \mathrm{~A}-30 \mathrm{R}-3,150$ & 282.40 & RPP & 17.8 & 46.2 & & $8.20 \mathrm{E}-05$ & 1 & 40.0 & Org & & & \\
\hline $766 \mathrm{~A}-30 \mathrm{R}-4,31$ & 282.71 & RP & 327.0 & 47.5 & 3.7 & $1.70 \mathrm{E}-04$ & 2 & 30.0 & 40.0 & Org & & \\
\hline $766 \mathrm{~A}-30 \mathrm{R}-4,75$ & 283.15 & $R$ & 88.9 & 46.7 & 4.7 & $1.54 \mathrm{E}-04$ & 3 & 30.0 & 35.0 & 40.0 & Org & \\
\hline $766 \mathrm{~A}-30 \mathrm{R}-4,125$ & 283.66 & $\mathrm{R}$ & 181.4 & 38.2 & 1.6 & $2.75 \mathrm{E}-04$ & 5 & 30.0 & 35.0 & 40.0 & 45.0 & 300 \\
\hline 766A-31R-1, 30 & 287.80 & RP & 9.4 & 40.4 & 9.6 & 1.37E-04 & 5 & 20.0 & 30.0 & 35.0 & 40.0 & 45.0 \\
\hline $766 \mathrm{~A}-31 \mathrm{R}-1,83$ & 288.33 & RP & 304.7 & 43.9 & 4.9 & 8.38E-05 & 2 & 30.0 & 40.0 & Org & & \\
\hline $766 \mathrm{~A}-31 \mathrm{R}-1,126$ & 288.76 & $\mathbf{R}$ & 129.7 & 59.6 & 3.9 & 2.18E-04 & 3 & 30.0 & 35.0 & 40.0 & Org & \\
\hline $766 \mathrm{~A}-31 \mathrm{R}-2,9$ & 289.09 & RPP & 38.4 & 72.0 & 38.8 & 3.17E-05 & 3 & 20.0 & 30.0 & 40.0 & Org & \\
\hline 766A-31R-2, 44 & 289.44 & RP & 175.8 & 54.0 & 4.1 & $1.60 \mathrm{E}-04$ & 3 & 30.0 & 35.0 & 40.0 & Org & \\
\hline $766 \mathrm{~A}-31 \mathrm{R}-2,117$ & 290.17 & RP & 71.6 & 30.2 & 4.3 & $1.11 \mathrm{E}-04$ & 3 & 30.0 & 35.0 & 40.0 & Org & \\
\hline 766A-31R-3, 28 & 290.78 & RP & 192.0 & 40.8 & 12.3 & 8.85E-0S & 6 & 25.0 & 30.0 & 35.0 & 40.0 & 45.0 \\
\hline 766A-32R-1, 12 & 297.32 & $\mathrm{~N}$ & 303.7 & -67.9 & 5.8 & $1.28 \mathrm{E}-04$ & 5 & 5.0 & 7.5 & 10.0 & 15.0 & 20.0 \\
\hline 766A-32R-1, 79 & 297.99 & $\mathrm{~N}$ & 218.9 & -57.3 & 6.9 & 1.57E-04 & 5 & 7.5 & 10.0 & 15.0 & 20.0 & 30.0 \\
\hline $766 \mathrm{~A}-32 \mathrm{R}-1,136$ & 298.56 & $\mathrm{~N}$ & 118.0 & -52.5 & 8.1 & $1.34 \mathrm{E}-04$ & 5 & 10.0 & 15.0 & 20.0 & 30.0 & 40.0 \\
\hline $766 \mathrm{~A}-32 \mathrm{R}-2,16$ & 298.86 & $\mathrm{~N}$ & 71.0 & -41.7 & 7.9 & $1.48 \mathrm{E}-04$ & 6 & 7.5 & 10.0 & 15.0 & 20.0 & 30.0 \\
\hline 766A-32R-2, 78 & 299.48 & NP & 77.3 & -48.2 & 15.8 & $1.57 \mathrm{E}-04$ & 5 & 10.0 & 15.0 & 20.0 & 25.0 & 35.0 \\
\hline $766 \mathrm{~A}-32 \mathrm{R}-2,136$ & 300.06 & NP & 93.2 & -36.6 & 18.9 & $2.04 \mathrm{E}-04$ & 4 & 10.0 & 15.0 & 20.0 & 30.0 & Org \\
\hline $766 \mathrm{~A}-32 \mathrm{R}-4,34$ & 302.04 & NP & 115.9 & -60.5 & 13.0 & $3.23 \mathrm{E}-04$ & 5 & 15.0 & 20.0 & 25.0 & 30.0 & 35.0 \\
\hline $766 \mathrm{~A}-32 \mathrm{R}-4,80$ & 302.54 & $N$ & 139.0 & -40.3 & 7.2 & $5.25 \mathrm{E}-04$ & 5 & 10.0 & 15.0 & 20.0 & 30.0 & 40.0 \\
\hline $766 \mathrm{~A}-32 \mathrm{R}-5,31$ & 303.51 & $\mathrm{~N}$ & 31.7 & -40.8 & 4.6 & $2.04 \mathrm{E}-02$ & 5 & 10.0 & 15.0 & 20.0 & 30.0 & 40.0 \\
\hline $766 \mathrm{~A}-32 \mathrm{R}-5,83$ & 304.03 & $\mathrm{~N}$ & 118.6 & -48.5 & 3.0 & $1.58 \mathrm{E}-02$ & 6 & 7.5 & 10.0 & 15.0 & 20.0 & 30.0 \\
\hline $766 \mathrm{~A}-33 \mathrm{R}-1,20$ & 307.00 & $\mathrm{~N}$ & 112.5 & -54.7 & 4.2 & $1.50 \mathrm{E}-02$ & 6 & 7.5 & 10.0 & 15.0 & 20.0 & 30.0 \\
\hline $766 \mathrm{~A}-33 \mathrm{R}-1,63$ & 307.43 & NP & 268.5 & -57.0 & 16.4 & $1.56 \mathrm{E}-02$ & 5 & 10.0 & 15.0 & 20.0 & 30.0 & 40.0 \\
\hline 766A-33R-1, 110 & 307.90 & $\mathrm{~N}$ & 232.3 & -46.6 & 3.0 & 1.25E-02 & 9 & 7.5 & 10.0 & 15.0 & 20.0 & 25.0 \\
\hline $766 \mathrm{~A}-33 \mathrm{R}-2,30$ & 308.60 & $\mathrm{~N}$ & 263.8 & -52.8 & 2.7 & $9.83 \mathrm{E}-03$ & 6 & 7.5 & 10.0 & 15.0 & 20.0 & 30.0 \\
\hline $766 \mathrm{~A}-33 \mathrm{R}-2,83$ & 309.13 & $\mathrm{~N}$ & 306.5 & -62.9 & 2.3 & $1.93 \mathrm{E}-02$ & 6 & 7.5 & 10.0 & 15.0 & 20.0 & 30.0 \\
\hline $766 \mathrm{~A}-33 \mathrm{R}-2,140$ & 309.73 & $\mathrm{~N}$ & 233.1 & -55.0 & 2.7 & $2.24 \mathrm{E}-02$ & 6 & 7.5 & 10.0 & 15.0 & 20.0 & 30.0 \\
\hline 766A-33R-3, 5 & 309.85 & $\mathrm{~N}$ & 143.4 & -54.0 & 3.1 & $1.52 \mathrm{E}-02$ & 5 & 10.0 & 15.0 & 20.0 & 30.0 & 40.0 \\
\hline $766 \mathrm{~A}-33 \mathrm{R}-3,73$ & 310.53 & $\mathrm{~N}$ & 49.6 & -56.5 & 2.0 & $2.04 \mathrm{E}-02$ & 6 & 7.5 & 10.0 & 15.0 & 20.0 & 30.0 \\
\hline 766A-34R-1, 51 & 317.01 & $\mathrm{~N}$ & 317.5 & -57.8 & 2.2 & 2.07E-02 & 5 & 10.0 & 15.0 & 20.0 & 30.0 & 40.0 \\
\hline $766 \mathrm{~A}-34 \mathrm{R}-1,147$ & 317.97 & RP & 344.5 & 58.2 & 7.7 & $1.76 \mathrm{E}-02$ & 2 & 20.0 & 30.0 & Org & & \\
\hline 766A-34R-2, 12 & 318.12 & $R$ & 277.5 & 65.9 & 1.1 & $1.06 \mathrm{E}-02$ & 3 & 30.0 & 40.0 & 45.0 & Org & \\
\hline $766 \mathrm{~A}-34 \mathrm{R}-2,86$ & 318.86 & RP & 213.4 & 49.4 & 6.2 & $3.51 \mathrm{E}-03$ & 3 & 30.0 & 40.0 & 45.0 & Org & \\
\hline $766 \mathrm{~A}-35 \mathrm{R}-1,14$ & 326.24 & $\mathbf{R}$ & 317.0 & 61.6 & 6.9 & $8.70 \mathrm{E}-03$ & 5 & 25.0 & 30.0 & 35.0 & 40.0 & 45.0 \\
\hline $766 \mathrm{~A}-36 \mathrm{R}-1,26$ & 336.06 & $\mathrm{R}$ & 350.7 & 48.6 & 3.6 & $2.52 \mathrm{E}-02$ & 4 & 20.0 & 30.0 & 35.0 & 40.0 & Org \\
\hline 766A-36R-1, 95 & 336.75 & $\mathrm{R}$ & 324.4 & 49.4 & 2.4 & $1.75 \mathrm{E}-02$ & 4 & 20.0 & 30.0 & 35.0 & 40.0 & Org \\
\hline 766A-36R-1, 143 & 337.23 & RP & 252.6 & 57.5 & 12.0 & $1.23 \mathrm{E}-02$ & 5 & 25.0 & 30.0 & 35.0 & 40.0 & 45.0 \\
\hline $766 \mathrm{~A}-36 \mathrm{R}-2,12$ & 337.42 & RP & 269.2 & 56.3 & & $6.22 \mathrm{E}-03$ & 1 & 40.0 & Org & & & \\
\hline $766 \mathrm{~A}-37 \mathrm{R}-1,18$ & 345.68 & $\mathbf{R}$ & 11.4 & 61.5 & 3.3 & $1.45 \mathrm{E}-02$ & 4 & 30.0 & 35.0 & 40.0 & 45.0 & Org \\
\hline $766 \mathrm{~A}-37 \mathrm{R}-1,84$ & 346.34 & RP & 271.1 & 44.0 & 2.3 & $2.00 \mathrm{E}-02$ & 2 & 20.0 & 30.0 & Org & & \\
\hline $766 \mathrm{~A}-37 \mathrm{R}-2,26$ & 347.26 & NPP & 29.7 & -21.2 & 17.5 & $1.37 \mathrm{E}-03$ & 3 & 30.0 & 35.0 & 40.0 & Org & \\
\hline $766 \mathrm{~A}-37 \mathrm{R}-2,120$ & 348.20 & $\mathrm{~N}$ & 141.5 & -53.4 & 5.2 & $1.42 \mathrm{E}-02$ & 7 & 15.0 & 20.0 & 25.0 & 30.0 & 35.0 \\
\hline $766 \mathrm{~A}-38 \mathrm{R}-1,41$ & 355.51 & $\mathrm{~N}$ & 172.0 & -50.8 & 3.5 & $7.65 \mathrm{E}-03$ & 4 & 20.0 & 30.0 & 35.0 & 40.0 & Org \\
\hline 766A-38R-2, 132 & 357.92 & $\mathbf{R}$ & 128.9 & 45.1 & 6.9 & $9.55 \mathrm{E}-03$ & 5 & 25.0 & 30.0 & 35.0 & 40.0 & 45.0 \\
\hline $766 \mathrm{~A}-38 \mathrm{R}-3,94$ & 359.04 & $\mathbf{R}$ & 333.4 & 45.0 & 2.7 & $1.71 \mathrm{E}-02$ & 3 & 15.0 & 20.0 & 30.0 & Org & \\
\hline $766 \mathrm{~A}-39 \mathrm{R}-1,85$ & 365.65 & $\mathbf{R}$ & 156.0 & 51.0 & 2.4 & $7.23 \mathrm{E}-03$ & 2 & 40.0 & 45.0 & Org & & \\
\hline 766A-39R-1, 134 & 366.14 & $\mathbf{R}$ & 206.3 & 56.0 & 5.7 & $2.46 \mathrm{E}-02$ & 7 & 15.0 & 20.0 & 25.0 & 30.0 & 35.0 \\
\hline $766 \mathrm{~A}-39 \mathrm{R}-2,15$ & 366.55 & $\mathbf{R}$ & 279.0 & 56.4 & 3.0 & $1.10 \mathrm{E}-02$ & 4 & 30.0 & 35.0 & 40.0 & 45.0 & Org \\
\hline $766 \mathrm{~A}-39 \mathrm{R}-2,108$ & 367.48 & $\mathbf{R}$ & 242.6 & 57.8 & 2.2 & $2.03 \mathrm{E}-02$ & 4 & 20.0 & 30.0 & 35.0 & 40.0 & Org \\
\hline
\end{tabular}




\begin{tabular}{|c|c|c|c|c|c|c|c|c|c|c|c|c|}
\hline & & & Charac & eristic directic & & & & & Dema & netizat & on step & used it \\
\hline interval (cm) & (mbsf) & Polarity & Declination & Inclination & Error & $(\mathrm{A} / \mathrm{m})$ & Total & & & ielected & Levels & $\mathrm{nT}$; or \\
\hline $766 \mathrm{~A}-39 \mathrm{R}-3,68$ & 368.58 & $\mathbf{R}$ & 276.9 & 60.4 & 1.8 & $1.77 \mathrm{E}-02$ & 4 & 15.0 & 20.0 & 30.0 & 40.0 & Org \\
\hline $766 \mathrm{~A}-39 \mathrm{R}-3,98$ & 368.88 & $\mathbf{R}$ & 351.8 & 62.9 & 3.2 & $1.40 \mathrm{E}-02$ & 4 & 20.0 & 30.0 & 35.0 & 40.0 & \\
\hline $766 \mathrm{~A}-40 \mathrm{R}-1,32$ & 374.82 & $\mathrm{~N}$ & 110.2 & -43.0 & 5.4 & $9.46 \mathrm{E}-03$ & 11 & 12.5 & 15.0 & 17.5 & 20.0 & 22.5 \\
\hline $766 \mathrm{~A}-40 \mathrm{R}-1,96$ & 375.46 & $\mathrm{~N}$ & 170.9 & -58.5 & 2.6 & $2.07 \mathrm{E}-02$ & 5 & 10.0 & 20.0 & 30.0 & 35.0 & 40.0 \\
\hline $766 \mathrm{~A}-40 \mathrm{R}-2,70$ & 376.70 & $\mathrm{~N}$ & 105.0 & -50.6 & 5.4 & $1.59 \mathrm{E}-02$ & 5 & 10.0 & 20.0 & 30.0 & 40.0 & 400 \\
\hline $766 \mathrm{~A}-40 \mathrm{R}-2,138$ & 377.38 & $\mathrm{~N}$ & 270.0 & -62.2 & 3.1 & $1.80 \mathrm{E}-02$ & 5 & 10.0 & 20.0 & 30.0 & 35.0 & 40.0 \\
\hline $766 \mathrm{~A}-40 \mathrm{R}-3,22$ & 377.72 & $\mathrm{~N}$ & 22.2 & -50.6 & 2.3 & $1.99 \mathrm{E}-02$ & 5 & 10.0 & 20.0 & 30.0 & 35.0 & 40.0 \\
\hline $766 \mathrm{~A}-40 \mathrm{R}-3,79$ & 378.29 & $\mathbf{R}$ & 160.0 & 58.0 & 1.0 & $1.20 \mathrm{E}-02$ & 4 & 20.0 & 30.0 & 35.0 & 40.0 & \\
\hline $766 \mathrm{~A}-40 \mathrm{R}-4,20$ & 379.20 & RPP & 24.3 & 62.9 & & $2.04 \mathrm{E}-03$ & 1 & 40.0 & Org & & & \\
\hline $766 \mathrm{~A}-40 \mathrm{R}-4,68$ & 379.68 & R & 313.7 & 55.4 & 5.1 & $1.18 \mathrm{E}-02$ & 7 & 25.0 & 30.0 & 35.0 & 40.0 & 45.0 \\
\hline $766 \mathrm{~A}-40 \mathrm{R}-4,127$ & 380.27 & RPP & 99.7 & 53.1 & 9.3 & $2.08 \mathrm{E}-03$ & 2 & 30.0 & 40.0 & Org & & \\
\hline $766 \mathrm{~A}-40 \mathrm{R}-5,19$ & 380.69 & RPP & 8.4 & 66.0 & & $2.09 \mathrm{E}-03$ & 1 & 40.0 & Org & & & \\
\hline $766 \mathrm{~A}-40 \mathrm{R}-5,83$ & 381.33 & $\mathbf{R}$ & 190.5 & 55.9 & 3.7 & $1.14 \mathrm{E}-02$ & 4 & 20.0 & 30.0 & 35.0 & 40.0 & \\
\hline $766 \mathrm{~A}-40 \mathrm{R}-5,141$ & 381.91 & $\mathbf{R}$ & 242.0 & 56.6 & 5.6 & $1.20 \mathrm{E}-02$ & 9 & 20.0 & 25.0 & 30.0 & 40.0 & 220 \\
\hline $766 \mathrm{~A}-40 \mathrm{R}-6,27$ & 382.27 & $\mathbf{R}$ & 335.3 & 56.6 & 3.3 & $9.50 \mathrm{E}-03$ & 4 & 20.0 & 30.0 & 35.0 & 45.0 & Org \\
\hline $766 \mathrm{~A}-40 \mathrm{R}-6,75$ & 382.75 & RPP & 70.5 & 26.9 & 6.8 & $1.45 \mathrm{E}-03$ & 2 & 40.0 & 45.0 & Org & & \\
\hline $766 \mathrm{~A}-40 \mathrm{R}-6,109$ & 383.09 & RP & 107.4 & 47.1 & 9.1 & $1.05 \mathrm{E}-02$ & 7 & 25.0 & 30.0 & 40.0 & 220 & 300 \\
\hline $766 \mathrm{~A}-40 \mathrm{R}-7,8$ & 383.58 & R?? & 99.1 & 55.2 & & $1.74 \mathrm{E}-03$ & 1 & 35.0 & Org & & & \\
\hline $766 \mathrm{~A}-40 \mathrm{R}-7,47$ & 383.97 & $\mathrm{R}$ & 339.7 & 61.8 & 1.6 & $6.74 \mathrm{E}-03$ & 3 & 30.0 & 35.0 & 40.0 & & \\
\hline $766 \mathrm{~A}-41 \mathrm{R}-1,11$ & 384.31 & RPP & 111.9 & 58.0 & 7.7 & $5.99 \mathrm{E}-03$ & 3 & 25.0 & 30.0 & 40.0 & Org & \\
\hline $766 \mathrm{~A}-4 \mid \mathrm{R}-1,79$ & 384.99 & $\mathrm{R}$ & 129.3 & 59.8 & 1.3 & $6.89 \mathrm{E}-03$ & 2 & 35.0 & 40.0 & Org & & \\
\hline $766 \mathrm{~A}-41 \mathrm{R}-1,134$ & 385.54 & RP & 148.1 & 60.4 & 11.9 & $1.25 \mathrm{E}-02$ & 5 & 20.0 & 30.0 & 35.0 & 40.0 & 45.0 \\
\hline $766 \mathrm{~A}-41 \mathrm{R}-2,17$ & 385.87 & $\mathbf{R}$ & 313.0 & 51.0 & 8.5 & $1.81 \mathrm{E}-02$ & 5 & 20.0 & 30.0 & 35.0 & 40.0 & 45.0 \\
\hline $766 \mathrm{~A}-41 \mathrm{R}-2,74$ & 386.44 & $\mathbf{R}$ & 47.2 & 57.4 & 5.9 & $5.62 \mathrm{E}-03$ & 4 & 20.0 & 35.0 & 40.0 & 30.0 & Org \\
\hline $766 \mathrm{~A}-41 \mathrm{R}-2,113$ & 386.83 & RP & 195.5 & 50.9 & 6.0 & $1.00 \mathrm{E}-02$ & 3 & 30.0 & 35.0 & 40.0 & Org & \\
\hline $766 \mathrm{~A}-41 \mathrm{R}-3,12$ & 387.32 & RPP & 119.6 & 53.9 & & $3.84 \mathrm{E}-03$ & 1 & 35.0 & Org & & & \\
\hline $766 \mathrm{~A}-41 \mathrm{R}-3,65$ & 387.85 & $\mathrm{R}$ & 346.8 & 60.5 & 3.9 & $1.08 \mathrm{E}-02$ & 5 & 30.0 & 40.0 & 200 & 300 & 350 \\
\hline $766 \mathrm{~A}-41 \mathrm{R}-3,123$ & 388.43 & $\mathrm{R}$ & 206.7 & 50.5 & 9.6 & $9.54 \mathrm{E}-03$ & 4 & 20.0 & 30.0 & 35.0 & 45.0 & Org \\
\hline $766 \mathrm{~A}-4 \mid \mathrm{R}-4,24$ & 388.94 & RP & 28.4 & 57.4 & 5.7 & $1.04 \mathrm{E}-02$ & 3 & 20.0 & 35.0 & 40.0 & Org & \\
\hline $766 \mathrm{~A}-41 \mathrm{R}-4,73$ & 389.43 & $\mathbf{R}$ & 156.5 & 58.1 & 5.3 & $2.57 \mathrm{E}-02$ & 5 & 10.0 & 20.0 & 30.0 & 35.0 & 40.0 \\
\hline $766 \mathrm{~A}-41 \mathrm{R}-4,129$ & 389.99 & $\mathrm{R}$ & 131.2 & 67.3 & 3.4 & $1.67 \mathrm{E}-02$ & 7 & 15.0 & 20.0 & 25.0 & 30.0 & 40.0 \\
\hline $766 A-41 R-5,16$ & 390.36 & $\mathbf{R}$ & 178.9 & 50.0 & 2.3 & $9.20 \mathrm{E}-03$ & 3 & 20.0 & 30.0 & 35.0 & Org & \\
\hline $766 \mathrm{~A}-41 \mathrm{R}-5,75$ & 390.95 & RP & 3.7 & 46.1 & 1.5 & $1.54 \mathrm{E}-02$ & 2 & 35.0 & 40.0 & Org & & \\
\hline $766 \mathrm{~A}-41 \mathrm{R}-5,127$ & 391.47 & RPP & 328.9 & 34.7 & & $5.68 \mathrm{E}-04$ & 1 & 40.0 & Org & & & \\
\hline $766 \mathrm{~A}-41 \mathrm{R}-6,8$ & 391.78 & $\mathrm{R}$ & 346.6 & 54.0 & 5.4 & $1.68 \mathrm{E}-02$ & 5 & 10.0 & 20.0 & 30.0 & 35.0 & 40.0 \\
\hline $766 \mathrm{~A}-42 \mathrm{R}-1,26$ & 394.06 & $\mathbf{R}$ & 158.3 & 56.1 & 2.6 & $1.55 \mathrm{E}-02$ & 3 & 30.0 & 40.0 & 200 & & \\
\hline $766 \mathrm{~A}-42 \mathrm{R}-1,86$ & 394.66 & $\mathbf{R}$ & 270.9 & 60.4 & 7.1 & $1.30 \mathrm{E}-02$ & 4 & 20.0 & 30.0 & 35.0 & 40.0 & Org \\
\hline $766 \mathrm{~A}-42 \mathrm{R}-1,129$ & 395.09 & RP & 209.8 & 53.0 & 11.0 & 3.37E-03 & 4 & 35.0 & 40.0 & 45.0 & 200 & Org \\
\hline $766 \mathrm{~A}-42 \mathrm{R}-2,18$ & 395.18 & $\mathbf{R}$ & 28.1 & 61.6 & 3.1 & $7.05 \mathrm{E}-03$ & 3 & 30.0 & 35.0 & 40.0 & Org & \\
\hline $766 \mathrm{~A}-42 \mathrm{R}-2,87$ & 396.17 & R & 263.1 & 59.5 & 2.9 & $1.48 \mathrm{E}-02$ & 3 & 40.0 & 35.0 & 45.0 & Org & \\
\hline $766 \mathrm{~A}-42 \mathrm{R}-2,133$ & 396.63 & RP & 204.2 & 56.5 & 6.5 & $4.08 \mathrm{E}-03$ & 2 & 35.0 & 45.0 & Org & & \\
\hline $766 \mathrm{~A}-42 \mathrm{R}-3,22$ & 397.02 & RP & 271.6 & 58.0 & 11.8 & $4.72 \mathrm{E}-03$ & 2 & 40.0 & 45.0 & Org & & \\
\hline $766 \mathrm{~A}-42 \mathrm{R}-3,80$ & 397.60 & $\mathrm{R}$ & 104.5 & 52.4 & 5.4 & $9.33 \mathrm{E}-03$ & 4 & 30.0 & 35.0 & 40.0 & 45.0 & Org \\
\hline $766 \mathrm{~A}-42 \mathrm{R}-3,136$ & 398.16 & $\mathbf{R}$ & 38.5 & 52.9 & 1.8 & $1.38 \mathrm{E}-02$ & 3 & 30.0 & 35.0 & 40.0 & Org & \\
\hline $766 \mathrm{~A}-42 \mathrm{R}-4,25$ & 398.55 & $\mathbf{R}$ & 222.0 & 60.1 & 2.3 & $1.83 \mathrm{E}-02$ & 3 & 25.0 & 30.0 & 40.0 & Org & \\
\hline $766 \mathrm{~A}-42 \mathrm{R}-4,93$ & 399.23 & RP & 107.3 & 58.0 & 4.4 & $3.51 \mathrm{E}-03$ & 3 & 30.0 & 35.0 & 40.0 & Org & \\
\hline $766 \mathrm{~A}-42 \mathrm{R}-4,144$ & 399.74 & RPP & 213.6 & 65.7 & & $9.13 \mathrm{E}-04$ & 1 & 40.0 & Org & & & \\
\hline $766 \mathrm{~A}-42 \mathrm{R}-5,4$ & 399.84 & NP & 23.2 & -62.4 & 3.1 & $4.47 \mathrm{E}-03$ & 3 & 10.0 & 20.0 & 30.0 & & \\
\hline $766 \mathrm{~A}-42 \mathrm{R}-5,56$ & 400.36 & $\mathrm{~N}$ & 22.6 & -60.3 & 4.7 & $1.27 \mathrm{E}-02$ & 4 & 10.0 & 20.0 & 30.0 & 40.0 & \\
\hline $766 \mathrm{~A}-42 \mathrm{R}-\mathrm{CC}, 8$ & 400.58 & $\mathrm{~N}$ & 206.3 & -58.7 & 4.4 & $1.30 \mathrm{E}-02$ & 7 & 15.0 & 20.0 & 25.0 & 30.0 & 35.0 \\
\hline $766 \mathrm{~A}-43 \mathrm{R}-1,32$ & 403.82 & $\mathrm{~N}$ & 216.7 & -58.9 & 2.3 & 3.30E-02 & 6 & 10.0 & 15.0 & 20.0 & 30.0 & 35.0 \\
\hline $766 \mathrm{~A}-43 \mathrm{R}-1,90$ & 404.40 & NP & 314.7 & -71.1 & 17.9 & $2.62 \mathrm{E}-02$ & 6 & 10.0 & 15.0 & 20.0 & 30.0 & 35.0 \\
\hline $766 \mathrm{~A}-43 \mathrm{R}-1,14 \mathrm{I}$ & 404.91 & $\mathrm{~N}$ & 307.2 & -55.8 & 3.9 & $1.53 \mathrm{E}-01$ & 5 & 7.5 & 10.0 & 20.0 & 30.0 & 40.0 \\
\hline $766 \mathrm{~A}-43 \mathrm{R}-2,27$ & 405.27 & NP & 36.4 & -37.6 & 5.2 & $1.97 \mathrm{E}-02$ & 4 & 20.0 & 30.0 & 35.0 & 40.0 & Org \\
\hline $766 \mathrm{~A}-43 \mathrm{R}-2,75$ & 405.75 & $\mathrm{~N}$ & 248.3 & -45.8 & 4.2 & 1.60E-02 & 7 & 15.0 & 20.0 & 25.0 & 30.0 & 35.0 \\
\hline $766 \mathrm{~A}-43 \mathrm{R}-2,135$ & 406.35 & NP & 353.0 & -52.3 & 5.8 & $4.38 \mathrm{E}-02$ & 4 & 15.0 & 20.0 & 30.0 & 35.0 & \\
\hline $766 \mathrm{~A}-43 \mathrm{R}-3,19$ & 406.59 & $\mathrm{~N}$ & 161.8 & -51.4 & 1.0 & $3.89 \mathrm{E}-02$ & 6 & 5.0 & 7.5 & 10.0 & 20.0 & 30.0 \\
\hline $766 \mathrm{~A}-43 \mathrm{R}-3,56$ & 407.06 & $\mathrm{~N}$ & 148.9 & -54.2 & 3.1 & $1.02 \mathrm{E}-02$ & 6 & 7.5 & 10.0 & 15.0 & 20.0 & 30.0 \\
\hline $766 \mathrm{~A}-43 \mathrm{R}-3,100$ & 407.50 & $\mathrm{~N}$ & 288.3 & -56.1 & 4.8 & $2.40 \mathrm{E}-02$ & 7 & 15.0 & 20.0 & 25.0 & 30.0 & 35.0 \\
\hline $766 \mathrm{~A}-43 \mathrm{R}-4,19$ & 408.69 & $\mathbf{R}$ & 75.4 & 55.3 & 3.8 & $1.34 \mathrm{E}-02$ & 4 & 20.0 & 30.0 & 35.0 & 40.0 & Org \\
\hline $766 \mathrm{~A}-43 \mathrm{R}-4,69$ & 409.19 & $\mathrm{R}$ & 158.5 & 52.5 & 2.7 & $1.72 \mathrm{E}-02$ & 5 & 15.0 & 20.0 & 25.0 & 30.0 & 40.0 \\
\hline $166 \mathrm{~A}-43 \mathrm{R}-4,134$ & 409.34 & $\mathrm{R}$ & 165.1 & 53.8 & 2.8 & $1.63 \mathrm{E}-02$ & 4 & 20.0 & 30.0 & 35.0 & 40.0 & Org \\
\hline $166 \mathrm{~A}-43 \mathrm{R}-5,19$ & 409.84 & $\mathrm{R}$ & 130.1 & 43.7 & 3.5 & $1.65 \mathrm{E}-02$ & 4 & 20.0 & 30.0 & 35.0 & 40.0 & Org \\
\hline $166 \mathrm{~A}-43 \mathrm{R}-5,76$ & 410.46 & $\mathrm{R}$ & 233.2 & 52.1 & 2.1 & $1.84 \mathrm{E}-02$ & 5 & 15.0 & 20.0 & 25.0 & 30.0 & 40.0 \\
\hline $66 \mathrm{~A}-43 \mathrm{R}-5,127$ & 410.87 & RP & 184.8 & 38.7 & 4.2 & $3.12 \mathrm{E}-03$ & 3 & 30.0 & 35.0 & 40.0 & Org & \\
\hline $66 \mathrm{~A}-44 \mathrm{R}-1,17$ & 413.37 & RP & 36.5 & 27.0 & 2.8 & $1.64 \mathrm{E}-02$ & 4 & 20.0 & 30.0 & 35.0 & 40.0 & Org \\
\hline $66 \mathrm{~A}-44 \mathrm{R}-1,72$ & 413.92 & $\mathbf{R}$ & 67.0 & 39.3 & 2.0 & $1.27 \mathrm{E}-02$ & 4 & 15.0 & 20.0 & 30.0 & 40.0 & Org \\
\hline $66 \mathrm{~A}-44 \mathrm{R}-1,126$ & 414.46 & $\mathrm{R}$ & 327.7 & 50.0 & 2.6 & $9.09 \mathrm{E}-03$ & 4 & 30.0 & 35.0 & 40.0 & 45.0 & Org \\
\hline $66 \mathrm{~A}-44 \mathrm{R}-2,18$ & 414.88 & RP & 252.1 & 45.2 & 7.8 & $1.71 \mathrm{E}-02$ & 4 & 20.0 & 30.0 & 35.0 & 40.0 & Org \\
\hline $66 \mathrm{~A}-44 \mathrm{R}-2,84$ & 415.54 & RP & 122.2 & 59.2 & 4.3 & $1.04 \mathrm{E}-03$ & 3 & 35.0 & 40.0 & 45.0 & Org & \\
\hline $66 \mathrm{~A}-44 \mathrm{R}-2,141$ & 416.11 & $\mathrm{R}$ & 187.6 & 42.3 & 2.4 & $1.06 \mathrm{E}-02$ & 4 & 20.0 & 30.0 & 35.0 & 40.0 & Org \\
\hline $66 \mathrm{~A}-44 \mathrm{R}-3,22$ & 416.42 & $\mathrm{R}$ & 7.4 & 50.4 & 3.0 & $1.29 \mathrm{E}-02$ & 3 & 30.0 & 35.0 & 40.0 & & \\
\hline $66 \mathrm{~A}-44 \mathrm{R}-3,72$ & 416.92 & $\mathrm{R}$ & 101.4 & 60.5 & 2.9 & 7.69E- 03 & 4 & 30.0 & 35.0 & 40.0 & 45.0 & Org \\
\hline $66 \mathrm{~A}-44 \mathrm{R}-3,125$ & 417.45 & $\mathrm{R}$ & 61.2 & 52.5 & 2.0 & $6.68 \mathrm{E}-03$ & 3 & 30.0 & 35.0 & 40.0 & Org & \\
\hline $66 \mathrm{~A}-44 \mathrm{R}-4,27$ & 417.97 & $\mathrm{R}$ & 186.5 & 47.1 & 1.7 & $3.58 \mathrm{E}-03$ & 3 & 30.0 & 35.0 & 40.0 & Org & \\
\hline $66 \mathrm{~A}-44 \mathrm{R}-4,70$ & 418.40 & RPP & 60.0 & 40.6 & & $3.92 \mathrm{E}-03$ & 1 & 15.0 & Org & & & \\
\hline $66 \mathrm{~A}-44 \mathrm{R}-4,126$ & 418.96 & $\mathrm{R}$ & 150.8 & 42.8 & 1.1 & $2.73 \mathrm{E}-03$ & 3 & 30.0 & 35.0 & 40.0 & Org & \\
\hline $66 \mathrm{~A}-44 \mathrm{R}-5,18$ & 419.38 & RPP & 260.1 & 30.4 & 3.1 & $1.42 \mathrm{E}-03$ & 3 & 30.0 & 35.0 & 40.0 & Org & \\
\hline $66 \mathrm{~A}-44 \mathrm{R}-5,78$ & 419.98 & $\mathbf{R}$ & 165.0 & 45.8 & 3.1 & $3.16 \mathrm{E}-03$ & 4 & 20.0 & 30.0 & 35.0 & 40.0 & Org \\
\hline $66 \mathrm{~A}-44 \mathrm{R}-5,132$ & 420.52 & $\mathbf{R}$ & 217.1 & 51.2 & 6.3 & $4.66 \mathrm{E}-03$ & 7 & 15.0 & 20.0 & 25.0 & 30.0 & 35.0 \\
\hline $66 \mathrm{~A}-44 \mathrm{R}-6,22$ & 420.92 & $\mathbf{R}$ & 313.7 & 45.1 & 4.4 & $2.26 \mathrm{E}-03$ & 4 & 35.0 & 40.0 & 45.0 & 30.0 & Org \\
\hline $66 \mathrm{~A}-44 \mathrm{R}-6,86$ & 421.56 & RP & 30.9 & 51.6 & 3.2 & $7.76 \mathrm{E}-05$ & 3 & 30.0 & 35.0 & 40.0 & Org & \\
\hline $66 \mathrm{~A}-45 \mathrm{R}-1,26$ & 423.06 & N?? & 100.5 & -10.4 & 4.5 & $4.21 \mathrm{E}-04$ & 3 & 30.0 & 35.0 & 40.0 & Org & \\
\hline $66 \mathrm{~A}-45 \mathrm{R}-1,74$ & 423.54 & RP & 345.1 & 51.9 & 0.8 & $4.07 \mathrm{E}-04$ & 2 & 35.0 & 40.0 & Org & & \\
\hline
\end{tabular}


Leg 123, Site 766

\begin{tabular}{|c|c|c|c|c|c|c|c|c|c|c|c|c|c|c|}
\hline \multirow{2}{*}{$\begin{array}{l}\text { Core, section, } \\
\text { interval }(\mathrm{cm})\end{array}$} & \multirow{2}{*}{$\begin{array}{l}\text { Meter level } \\
\text { (mbsf) }\end{array}$} & \multirow[b]{2}{*}{ Polarity } & \multicolumn{3}{|c|}{ Characteristic direction } & \multirow{2}{*}{$\begin{array}{l}\text { Mean intensity } \\
(A / m)\end{array}$} & \multicolumn{8}{|c|}{ Demagnetization steps used in least-squares } \\
\hline & & & Declination & Inclination & Error & & Total & & & Selected & Levels ( & nT; or & legrees $\mathrm{i}$ & $f>100)$ \\
\hline $766 \mathrm{~A}-45 \mathrm{R}-1,132$ & 424.12 & RP & 141.3 & 52.2 & 1.6 & $6.84 \mathrm{E}-04$ & 2 & 35.0 & 40.0 & Org & & & & \\
\hline $766 \mathrm{~A}-45 \mathrm{R}-2,24$ & 424.54 & RP & 238.9 & 41.3 & 9.1 & $5.24 \mathrm{E}-04$ & 3 & 30.0 & 35.0 & 45.0 & Org & & & \\
\hline 766 A-45R-2, 72 & 425.02 & RP & 164.2 & 40.8 & 8.8 & $1.11 \mathrm{E}-03$ & 5 & 20.0 & 25.0 & 30.0 & 35.0 & 45.0 & Org & \\
\hline 766A-45R-2, 125 & 425.55 & NPP & 335.6 & -64.9 & 13.6 & $1.09 \mathrm{E}-04$ & 2 & 35.0 & 40.0 & Org & & & & \\
\hline $766 \mathrm{~A}-45 \mathrm{R}-3,6$ & 425.86 & NPP & 95.3 & -73.0 & 2.0 & $2.09 \mathrm{E}-04$ & 3 & 30.0 & 35.0 & 40.0 & Org & & & \\
\hline $766 \mathrm{~A}-45 \mathrm{R}-3,81$ & 426.61 & NPP & 185.0 & -30.2 & 14.0 & $1.12 \mathrm{E}-04$ & 3 & 30.0 & 35.0 & 40.0 & Org & & & \\
\hline 766A-45R-3, 126 & 427.06 & RPP & 125.4 & 34.5 & 18.8 & $1.77 E-04$ & 4 & 20.0 & 30.0 & 35.0 & 40.0 & Org & & \\
\hline $766 \mathrm{~A}-45 \mathrm{R}-4,34$ & 427.64 & RPP & 310.6 & 41.3 & & $2.06 \mathrm{E}-04$ & 1 & 30.0 & Org & & & & & \\
\hline $766 \mathrm{~A}-45 \mathrm{R}-4,80$ & 428.10 & NPP & 135.9 & -58.5 & 5.8 & $1.93 \mathrm{E}-04$ & 2 & 20.0 & 35.0 & Org & & & & \\
\hline $766 \mathrm{~A}-45 \mathrm{R}-4,134$ & 428.64 & NP & 354.5 & -61.4 & 5.5 & $1.49 \mathrm{E}-04$ & 3 & 30.0 & 35.0 & 40.0 & Org & & & \\
\hline 766A-45R-5, 20 & 429.00 & NPP & 41,8 & -40.1 & 4.7 & 2.34E-04 & 3 & 20.0 & 30.0 & 35.0 & Org & & & \\
\hline 766A-45R-5, 77 & 429.57 & NPP & 74.9 & -70.3 & 10.9 & $7.52 \mathrm{E}-05$ & 4 & 20.0 & 30.0 & 35.0 & 40.0 & & & \\
\hline 766A-45R-5, 140 & 430.20 & $\mathrm{R} ?$ ? & 347.0 & 15.0 & & $9.74 \mathrm{E}-05$ & 1 & 35.0 & Org & & & & & \\
\hline 766A-4SR-6, 18 & 430.48 & NPP & 165.2 & -24.8 & 4.7 & $1.17 \mathrm{E}-04$ & 4 & 25.0 & 30.0 & 35.0 & 45.0 & Org & & \\
\hline 766A-45R-6, 78 & 431.08 & NP & 111.2 & -60.4 & 5.7 & $1.46 \mathrm{E}-04$ & 3 & 20.0 & 30.0 & 40.0 & Org & & & \\
\hline 766A-45R-6, 129 & 431.59 & NP & 158.4 & -49.6 & 6.7 & $1.93 \mathrm{E}-04$ & 4 & 10.0 & 20.0 & 30.0 & 35.0 & & & \\
\hline $766 \mathrm{~A}-45 \mathrm{R}-7,36$ & 432.16 & NP & 136.1 & -42.3 & 6.5 & 2.44E-04 & 4 & 10.0 & 20.0 & 30.0 & 35.0 & & & \\
\hline $766 \mathrm{~A}-46 \mathrm{R}-1,13$ & 432.63 & NP & 48.9 & -60.2 & 6.4 & $2.80 \mathrm{E}-04$ & 5 & 10.0 & 15.0 & 20.0 & 25.0 & 30.0 & Org & \\
\hline $766 \mathrm{~A}-46 \mathrm{R}-1,82$ & 433.32 & NPP & 228.7 & -78.7 & 4.9 & $1.51 E-04$ & 2 & 30.0 & 35.0 & Org & & & & \\
\hline $766 \mathrm{~A}-46 \mathrm{R}-2,12$ & 434.12 & NPP & 154.3 & -37.6 & 13.9 & $1.94 \mathrm{E}-04$ & 3 & 20.0 & 30.0 & 35.0 & Org & & & \\
\hline $766 \mathrm{~A}-46 \mathrm{R}-2,88$ & 434.88 & RPP & 135.0 & 36.0 & 4.0 & $9.22 \mathrm{E}-05$ & 2 & 30.0 & 35.0 & Org & & & & \\
\hline $766 \mathrm{~A}-46 \mathrm{R}-2,129$ & 435.29 & INT & 131.2 & 30.9 & 27.2 & $1.07 \mathrm{E}-04$ & 4 & 35.0 & 37.5 & 40.0 & 45.0 & Org & & \\
\hline $766 \mathrm{~A}-46 \mathrm{R}-3.21$ & 435.71 & $\begin{array}{l}\text { N?? } \\
\text { N?? }\end{array}$ & $\begin{array}{r}82.9 \\
349.8\end{array}$ & $\begin{array}{l}-56.7 \\
-49.3\end{array}$ & $\begin{array}{l}10.4 \\
12.3\end{array}$ & $\begin{array}{l}1.54 \mathrm{E}-04 \\
1.44 \mathrm{E}-04\end{array}$ & $\begin{array}{l}2 \\
2\end{array}$ & $\begin{array}{l}20.0 \\
10.0\end{array}$ & $\begin{array}{l}30.0 \\
20.0\end{array}$ & $\begin{array}{l}\text { Org } \\
\text { Org }\end{array}$ & & & & \\
\hline $\begin{array}{l}766 \mathrm{~A}-46 \mathrm{R}-3,98 \\
766 \mathrm{~A}-46 \mathrm{R}-4,10\end{array}$ & $\begin{array}{l}436.48 \\
437.10\end{array}$ & $\begin{array}{l}\text { N?? } \\
\text { RPP }\end{array}$ & $\begin{array}{l}349.8 \\
206.9\end{array}$ & $\begin{array}{r}-4.3 \\
31.1\end{array}$ & $\begin{array}{r}12.3 \\
9.1\end{array}$ & $\begin{array}{l}1.44 \mathrm{E}-04 \\
6.38 \mathrm{E}-04\end{array}$ & 3 & 30.0 & 35.0 & $\begin{array}{l}0.9 \\
40.0\end{array}$ & Org & & & \\
\hline $\begin{array}{l}766 \mathrm{~A}-46 \mathrm{R}-4,10 \\
766 \mathrm{~A}-46 \mathrm{R}-4,97\end{array}$ & $\begin{array}{l}437.10 \\
437.97\end{array}$ & RP & 293.7 & 41.1 & 5.8 & $9.25 \mathrm{E}-04$ & 4 & 20.0 & 30.0 & 35.0 & 40.0 & Org & & \\
\hline $766 \mathrm{~A}-46 \mathrm{R}-5,31$ & 438.81 & $\mathbf{R}$ & 246.3 & 43.0 & 3.4 & $7.45 \mathrm{E}-03$ & 4 & 20.0 & 30.0 & 35.0 & 40.0 & Org & & \\
\hline $766 \mathrm{~A}-46 \mathrm{R}-5,91$ & 439.41 & $\mathrm{R}$ & 44.3 & 44.5 & 5.2 & $1.69 \mathrm{E}-03$ & 4 & 20.0 & 30.0 & 35.0 & 40.0 & Org & & \\
\hline $766 \mathrm{~A}-46 \mathrm{R}-6,19$ & 440.19 & RP & 258.0 & 34.8 & 5.0 & $7.31 \mathrm{E}-04$ & 3 & 30.0 & 35.0 & 40.0 & Org & & & \\
\hline $766 \mathrm{~A}-46 \mathrm{R}-6,73$ & 440.73 & $R P$ & 206.3 & 29.2 & 2.6 & $1.85 \mathrm{E}-03$ & 3 & 30.0 & 35.0 & 40.0 & Org & & & \\
\hline $766 \mathrm{~A}-46 \mathrm{R}-7,11$ & 441.61 & $\mathrm{~N}$ & 111.9 & -60.6 & 1.7 & $1.70 \mathrm{E}-03$ & 4 & 30.0 & 35.0 & 40.0 & 45.0 & Org & & \\
\hline $766 \mathrm{~A}-47 \mathrm{R}-1,22$ & 442.42 & $\mathrm{~N}$ & 216.5 & -48.0 & 1.7 & 8.87 E- 03 & 3 & 30.0 & 35.0 & 40.0 & Org & & & \\
\hline $766 \mathrm{~A}-47 \mathrm{R}-1,87$ & 443.07 & $\mathrm{~N}$ & 47.0 & -45.5 & 6.6 & $4.68 \mathrm{E}-03$ & 4 & 20.0 & 30.0 & 35.0 & 40.0 & & & \\
\hline $766 \mathrm{~A}-47 \mathrm{R}-1,141$ & 443.61 & NP & 197.9 & -43.3 & 8.1 & $5.92 \mathrm{E}-03$ & 4 & 20.0 & 30.0 & 35.0 & 40.0 & Org & & \\
\hline $766 \mathrm{~A}-47 \mathrm{R}-2,35$ & 444.05 & $\mathrm{~N}$ & 174.8 & -44.6 & 9.5 & $7.45 \mathrm{E}-03$ & 5 & 10.0 & 20.0 & 30.0 & 35.0 & 40.0 & & \\
\hline $766 \mathrm{~A}-47 \mathrm{R}-2,113$ & 444.83 & NP & 290.8 & -56.5 & 5.6 & $3.56 \mathrm{E}-03$ & 4 & 20.0 & 30.0 & 35.0 & 40.0 & Org & & \\
\hline $766 \mathrm{~A}-47 \mathrm{R}-3,20$ & 445.40 & $\mathrm{~N}$ & 293.4 & -58.4 & 5.8 & $4.22 \mathrm{E}-03$ & 5 & 10.0 & 20.0 & 30.0 & 35.0 & 40.0 & & \\
\hline $766 \mathrm{~A}-47 \mathrm{R}-3,70$ & 445.90 & NP & 241.0 & -45.1 & 8.0 & 9.77E-03 & 4 & 20.0 & 30.0 & 35.0 & 40.0 & Org & & \\
\hline $766 \mathrm{~A}-47 \mathrm{R}-3,144$ & 446.64 & $N$ & 75.8 & -45.3 & 1.6 & $9.08 \mathrm{E}-03$ & 5 & 10.0 & 20.0 & 30.0 & 35.0 & 40.0 & Org & \\
\hline $766 \mathrm{~A}-47 \mathrm{R}-4,42$ & 447.12 & $\mathrm{~N}$ & 68.8 & -54.5 & 2.2 & $1.23 \mathrm{E}-02$ & 5 & 10.0 & 20.0 & 30.0 & 35.0 & 40.0 & & \\
\hline $766 \mathrm{~A}-47 \mathrm{R}-4,111$ & 447.81 & $\mathrm{~N}$ & 337.3 & -55.2 & 3.0 & $1.71 \mathrm{E}-02$ & 5 & 10.0 & 20.0 & 30.0 & 35.0 & 40.0 & & \\
\hline 766A-47R-5, 92 & 449.22 & $N$ & 89.5 & -46.9 & 2.8 & $2.29 \mathrm{E}-02$ & 5 & 10.0 & 15.0 & 20.0 & 30.0 & 40.0 & & \\
\hline 766A-47R-5, 145 & 449.72 & NP & 291.2 & -49.7 & 6.9 & $1.14 \mathrm{E}-02$ & 5 & 10.0 & 20.0 & 30.0 & 35.0 & 40.0 & & \\
\hline $766 \mathrm{~A}-47 \mathrm{R}-6,36$ & 450.16 & $\mathrm{~N}$ & 275.6 & -40.2 & 3.7 & $2.59 \mathrm{E}-02$ & 5 & 10.0 & 15.0 & 20.0 & 30.0 & 40.0 & & \\
\hline $766 \mathrm{~A}-47 \mathrm{R}-6,111$ & 450.81 & $\mathrm{~N}$ & 99.0 & -56.8 & 5.5 & $1.72 \mathrm{E}-02$ & 6 & 7.5 & 10.0 & 20.0 & 30.0 & 35.0 & 40.0 & \\
\hline $766 \mathrm{~A}-47 \mathrm{R}-7,57$ & 451.77 & $\mathrm{~N}$ & 28.9 & -46.8 & 4.6 & $1.91 \mathrm{E}-02$ & 5 & 10.0 & 20.0 & 30.0 & 35.0 & 40.0 & & \\
\hline $766 \mathrm{~A}-48 \mathrm{R}-1,20$ & 452.00 & $\mathrm{~N}$ & 280.3 & -40.3 & 4.2 & $2.29 \mathrm{E}-02$ & 5 & 10.0 & 20.0 & 30.0 & 35.0 & 40.0 & & \\
\hline $766 \mathrm{~A}-48 \mathrm{R}-1,62$ & 452.42 & NP & 176.1 & -45.0 & 10.1 & $1.66 \mathrm{E}-02$ & 5 & 10.0 & 20.0 & 30.0 & 35.0 & 40.0 & & \\
\hline $766 \mathrm{~A}-48 \mathrm{R}-2,8$ & 453.38 & $\mathrm{~N}$ & 156.7 & -48.2 & 1.1 & 1.35E-02 & 5 & 7.5 & 10.0 & 20.0 & 30.0 & 35.0 & & \\
\hline $766 \mathrm{~A}-48 \mathrm{R}-2,58$ & 453.88 & NPP & 36.6 & -71.1 & & $7.90 \mathrm{E}-03$ & 1 & 40.0 & Org & & & & & \\
\hline $766 \mathrm{~A}-48 \mathrm{R}-3,13$ & 454.93 & $\mathrm{~N}$ & 155.7 & -45.5 & 4.2 & $1.52 \mathrm{E}-02$ & 7 & 5.0 & 10.0 & 30.0 & 35.0 & 40.0 & 7.5 & 16.0 \\
\hline $766 \mathrm{~A}-48 \mathrm{R}-3,48$ & 455.28 & $\mathrm{~N}$ & 131.6 & -37.1 & 5.7 & $1.83 \mathrm{E}-02$ & 5 & 10.0 & 20.0 & 30.0 & 35.0 & 40.0 & & \\
\hline $766 \mathrm{~A}-48 \mathrm{R}-4,30$ & 456.60 & RP & 338.0 & 31.7 & 6.2 & $1.08 \mathrm{E}-02$ & 5 & 20.0 & 25.0 & 30.0 & 35.0 & 40.0 & Org & \\
\hline $766 \mathrm{~A}-48 \mathrm{R}-4,118$ & 457.48 & RP & 301.3 & 42.7 & 1.7 & $1.58 \mathrm{E}-02$ & 3 & 35.0 & 40.0 & 45.0 & Org & & & \\
\hline $766 \mathrm{~A}-48 \mathrm{R}-5,50$ & 458.30 & RP & 262.3 & 50.2 & 5.3 & $1.27 \mathrm{E}-02$ & 5 & 20.0 & 30.0 & 35.0 & 40.0 & 45.0 & Org & \\
\hline 766A-48R-5, 112 & 458.92 & $\mathbf{R}$ & 75.7 & 53.7 & 5.6 & $2.24 \mathrm{E}-02$ & 5 & 25.0 & 30.0 & 35.0 & 40.0 & 45.0 & Org & \\
\hline 766A-48R-6, 38 & 459.68 & $\mathrm{R}$ & 283.9 & 51.7 & 4.2 & $5.78 \mathrm{E}-03$ & 4 & 30.0 & 35.0 & 40.0 & 45,0 & Org & & \\
\hline $766 \mathrm{~A}-48 \mathrm{R}-6,97$ & 460.27 & $\mathrm{R}$ & 260.5 & 46.1 & 4.6 & $1.58 \mathrm{E}-02$ & 4 & 20.0 & 25.0 & 30.0 & 35.0 & Org & & \\
\hline $766 \mathrm{~A}-49 \mathrm{R}-1,90$ & 462.40 & RP & 208.1 & 63.8 & 8.4 & $2.08 \mathrm{E}-02$ & 4 & 20.0 & 30.0 & 40.0 & 45.0 & & & \\
\hline $766 \mathrm{~A}-49 \mathrm{R}-1,143$ & 462.93 & RP & 247.5 & 36.0 & 7.8 & $7.71 \mathrm{E}-03$ & 3 & 30.0 & 35.0 & 40.0 & Org & & & \\
\hline $766 \mathrm{~A}-49 \mathrm{R}-2,24$ & 463.24 & $\mathbf{R}$ & 209.1 & 49.7 & 7.2 & $2.05 \mathrm{E}-02$ & 5 & 20.0 & 30.0 & 35.0 & 40.0 & 45.0 & Org & \\
\hline $766 \mathrm{~A}-49 \mathrm{R}-2,77$ & 463.77 & RP & 23.0 & 40.4 & 5.0 & $1.52 \mathrm{E}-03$ & 3 & 35.0 & 40.0 & 45.0 & Org & & & \\
\hline $766 \mathrm{~A}-49 \mathrm{R}-2,116$ & 464.16 & RPP & 198.7 & 35.6 & 5.6 & $8.62 \mathrm{E}-03$ & 3 & 35.0 & 40.0 & 45.0 & Org & & & \\
\hline $766 \mathrm{~A}-49 \mathrm{R}-3,40$ & 464.90 & $\mathbf{R}$ & 175.7 & 51.3 & 11.1 & $3.10 \mathrm{E}-02$ & 6 & 20.0 & 25.0 & 30.0 & 35.0 & 40.0 & 45.0 & \\
\hline $766 \mathrm{~A}-49 \mathrm{R}-3,77$ & 465.27 & $\mathbf{R}$ & 322.9 & 45.8 & 4.5 & $4.84 \mathrm{E}-03$ & 3 & 30.0 & 35.0 & 40.0 & Org & & & \\
\hline 766A-49R-3. 120 & 465.70 & $\mathbf{R}$ & 183.5 & 37.5 & 2.2 & $1.92 \mathrm{E}-03$ & 4 & 30.0 & 35.0 & 40.0 & 45.0 & Org & & \\
\hline $766 \mathrm{~A}-49 \mathrm{R}-3,145$ & 465.95 & R?? & 57,9 & 73.4 & 6.9 & $3.73 \mathrm{E}-02$ & 4 & 30.0 & 35.0 & 40.0 & 45.0 & & & \\
\hline $766 \mathrm{~A}-49 \mathrm{R}-4,38$ & 466.38 & RP & 3.6 & 31.4 & 3.8 & $1.98 \mathrm{E}-03$ & 4 & 30.0 & 35.0 & 40.0 & 45.0 & Org & & \\
\hline $766 \mathrm{~A}-49 \mathrm{R}-4,62$ & 466.62 & $\mathbf{R}$ & 282.3 & 42.8 & 1.3 & $1.63 \mathrm{E}-02$ & 5 & 10.0 & 20.0 & 30.0 & 35.0 & 40.0 & & \\
\hline
\end{tabular}

